\title{
Composition and Property Measurements for PHA Phase 3 Glasses
}

by

T. B. Edwards

Westinghouse Savannah River Company

Savannah River Site

Aiken, South Carolina 29808

J. R. Harbour

R. J. Workman

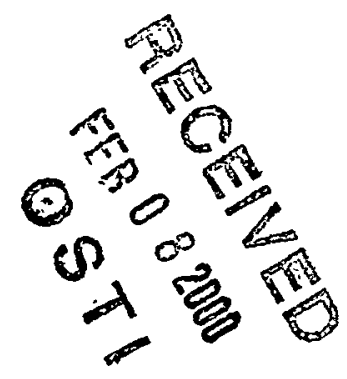

।

DOE Contract No. DE-AC09-96SR18500

This paper was prepared in connection with work done under the above contract number with the U. S.

Department of Energy. By acceptance of this paper, the publisher and/or recipient acknowledges the U. S. Government's right to retain a nonexclusive, royalty-free license in and to any copyright covering this paper, along with the right to reproduce and to authorize others to reproduce all or part of the copyrighted paper. 
WSRC-TR-99-00292

Revision 0

Keywords: Coupled Operations DWPF, PCT, PCCS, Liquidus Temperature, Salt Disposition, Viscosity

Retention Time: Permanent

\section{Composition AND Property Measurements FOR PHA PHASe 3 Glasses (U)}

T. B. Edwards

J. R. Harbour

R. J. Workman

Westinghouse Savannah River Company

Savannah River Technology Center Aiken, SC 29808

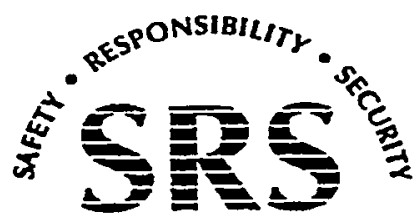

SAVANNAH RIVER SITE

PREPARED FOR THE US. DEPARTMENT OF ENERGY UNDER CONTRACT NO. DE-AC09-96SR18500 
WSRC-TR-99-00292

Revision 0

\section{DISCLAIMER}

This report was prepared as an account of work sponsored by an agency of the United States Government. Neither the United. States Government nor any agency thereof, nor any of their employees, makes any warranty, express or implied, or assumes any legal liability or responsibility for the accuracy, completeness, or usefulness of any information, apparatus, product, or process disclosed, or represents that its use would not infringe privately owned rights. Reference herein to any speciñc commercial product, process, or service by trade name, trademark, manufacturer, or otherwise does not necessarily constitute or imply its endorsement, recommendation, or favoring by the United States Government or any agency thereof. The views and opinions of authors expressed herein do not necessarily state or reflect those of the United States Government or any agency thereof.

This report has been reproduced directly from the best available copy.

Available to DOE and DOE contractors from the Office of Scientific and Technical Information, P.O. Box 62, Oak Ridge, TN 37831; prices available from (615) 576-8401.

Available to the public from the National Technical Information Service, U.S. Department of Commerce, 5285 Port Royal Road, Springfield, VA 22161. 


\section{DISCLAIMER}

Portions of this document may be illegible in electronic image products. Images are produced from the best available original document. 


\title{
Composition AND Property Measurements FOR PHA Phase 3 Glasses (U)
}

\author{
August 18, 1999
}

Document Approvals

Ohomes \& Edeverds

T. B. Edwards, Author Statistical Consulting Section

\section{Giln R Harlour}

J. R./Harbour, Author Immobilization Technology Section

Phunda 9. Wontene

R. J. Workman, Author

Immobilization Technology Section

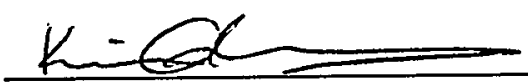

K. G. Brown, Technical Review Immobilization Technology Section

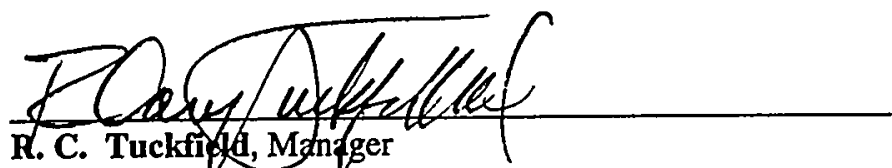
Statistical Corlsulting Section

\section{Eustoetzacheres}

E. W. Holtzsch eiter, Manager Immobilization Technology Section Authorized Derivative Classifier
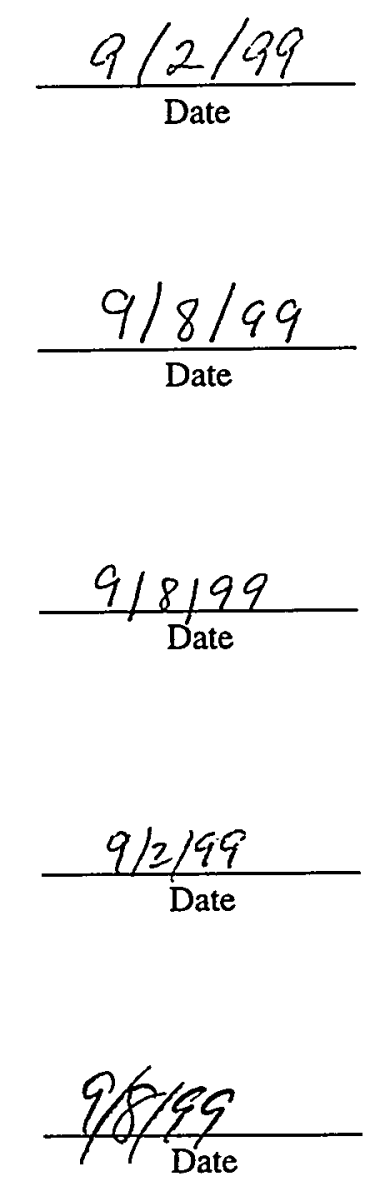

$\frac{9-8-99}{\text { Date }}$ 
WSRC-TR-99-00292

Revision 0

This page intentionally left blank.

WSRC Confidentat and Proprietary Infomation. 


\section{TABLE OF CONTENTS}

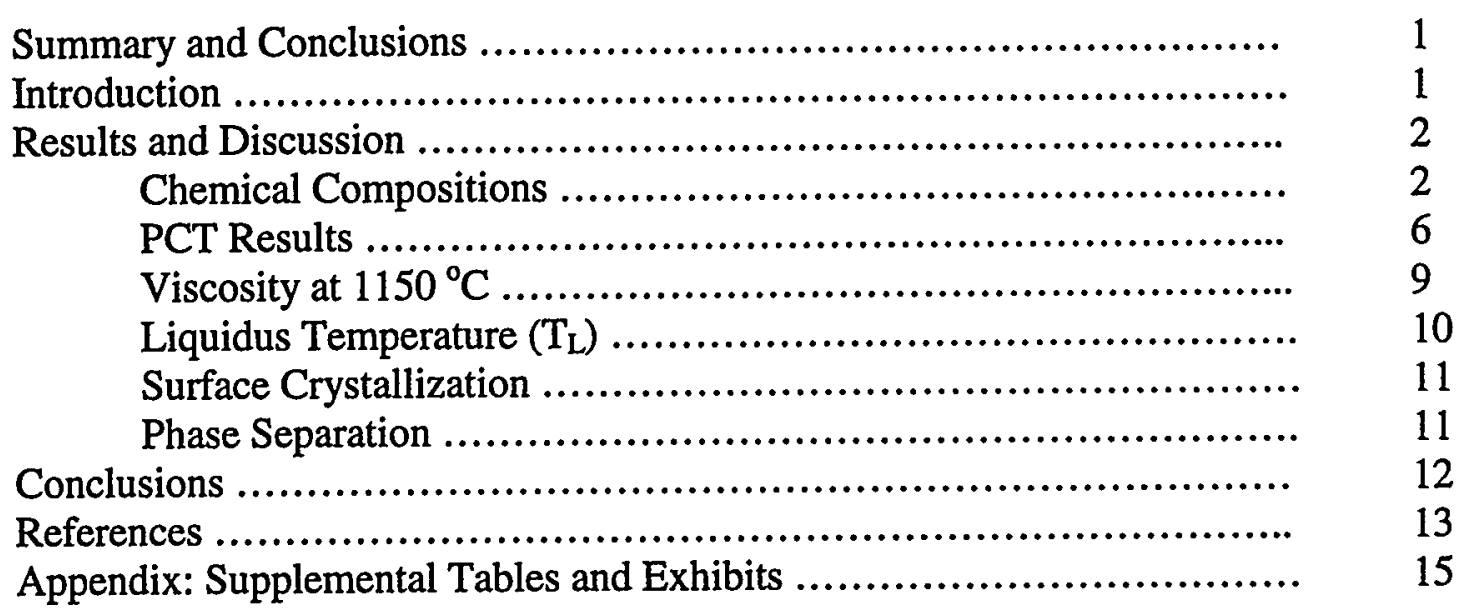


WSRC-TR-99-00292

Revision 0

This page intentionally left blank.

WSRC Confidentiai and Proprietary Infomation. 


\section{SUMMARY AND CONCLUSIONS}

The results presented in this report are for six Phase 3 Precipitate Hydrolysis Aqueous (PHA) glasses, each of which was targeted to contain 22 wt\% simulated PUREX sludge on an oxide basis. The target PHA concentration was varied from 7 to 10 to $13 \mathrm{wt} \%$ oxides both at 1.25 and $2.5 \mathrm{wt} \%$ (on an oxide basis) washed monosodium titanate (MST).

All six of these glasses were durable when compared to the Environmental Assessment (EA) glass (as determined by the 7-day Product Consistency Test, the PCT) and processible (from measured viscosity and bounding liquidus temperature data). Therefore, the results imply that the Defense Waste Processing Facility (DWPF) would be able to run these six glass formulations at 22 wt \% PUREX waste loading on an oxide basis.

The models currently in DWPF's Product Composition Control System (PCCS) were used to predict durability, homogeneity, liquidus, and viscosity for these six glasses. All six glasses were predicted to be phase separated, and consequently prediction of glass durability is precluded with the current models. However, the measured durabilities (as determined by the PCT) were within the 95\% confidence bands of the model. Further efforts will be required to resolve this issue on phase separation (inhomogeneity).

The liquidus model predicted acceptable liquidus temperatures for all six glasses. The bounding liquidus temperatures that were measured $\left(<900^{\circ} \mathrm{C}\right)$ were below the model predictions. The measured viscosities were below the predictions of the model and therefore, conservative to the upper limit of viscosity. The lowest measured viscosity value was 33.1 poise at $1150^{\circ} \mathrm{C}$, corresponding to the glass with the highest level of PHA and at the lower level of MST. The model predictions may not be conservative with respect to the lower operating limit.

\section{INTRODUCTION}

One of the Alternative Salt Disposition Flowsheets being considered would require that the Defense Waste Processing Facility (DWPF) vitrify a coupled feed containing high level waste (HLW) and Precipitate Hydrolysis Aqueous (PHA). A Technical Task Request (TTR) [1] was received by the Savannah River Technology Center (SRTC) requesting that a glass variability study be conducted to explore the processability and product quality of the glass composition region for this alternative to the In-Tank Precipitation (ITP) Process. A Task Technical and Quality Assurance (TT\&QA) plan [2] was issued by SRTC in response to the TTR. The objective of this task is to obtain information on the feasibility of incorporating anticipated levels of PHA into DWPF glass with and without doubling the nominal levels of monosodium titanate (MST).

A set of target compositions from which the glasses supporting this task are to be selected was provided in the memorandum appearing as Attachment I of [3]. Process and product property predictions for these glasses are also provided in that attachment. The candidate glasses identified involved three sludge types: Purex, HM, and Blend; covered sludge loadings (in the glass) of 22, 26, and 30 oxide weight percent (wt\%); utilized PHA loadings (in the glass) of 7, 10, and 13 oxide wt\%; and included MST concentrations (in the glass) at 1.25 and $2.5 \mathrm{wt} \%$. For each composition, the remainder of the glass consisted of Frit 202. The glasses, batched, and fabricated using the Purex sludge at a target loading of $22 \mathrm{wt} \%$ of the glass, were selected to comprise Phase 3 of this study. The general, target compositions of these glasses are provided in Table 1. 
Table 1: General Composition of the PHA Phase 3 Glasses

\begin{tabular}{|ccccc|}
\hline Glass ID & $\begin{array}{c}\text { Purex } \\
\text { Sludge }\end{array}$ & PHA & MST & Frit \\
pha01 & $22 \%$ & $7 \%$ & $1.25 \%$ & $69.75 \%$ \\
pha02 & $22 \%$ & $10 \%$ & $1.25 \%$ & $66.75 \%$ \\
pha03 & $22 \%$ & $13 \%$ & $1.25 \%$ & $63.75 \%$ \\
pha04 & $22 \%$ & $7 \%$ & $2.5 \%$ & $68.50 \%$ \\
pha05 & $22 \%$ & $10 \%$ & $2.5 \%$ & $65.50 \%$ \\
pha06 & $22 \%$ & $13 \%$ & $2.5 \%$ & $62.50 \%$ \\
\hline
\end{tabular}

The properties of interest for these glasses included durability (as measured by the 7-day Product Consistency Test $(\mathrm{PCT})[4])$, viscosity at $1150^{\circ} \mathrm{C}$, and liquidus temperature. The purpose of this report is to provide and investigate comparisons between

- the measured and target compositions of this set of Phase 3 PHA glasses and

- the property measurements and their predictions.

The impact of these results on the path forward selected for this preliminary, PHA glass variability study will also be discussed.

\section{RESULTS AND DISCUSSION}

The six glasses comprising Phase 3 of the PHA study were designated as pha01 through pha06. Composition and property measurements of these glasses were conducted in parallel with the six glasses comprising Phase 3 of the other ITP replacement alternative, designated as the CST (Crystalline Silicotitanate) study. This approach helps ensure that the PHA and CST glasses are fabricated, characterized, and analyzed under very similar conditions. The CST Phase 3 results were reported in [5], and included in the attachments of that report are the analytical plans that were used to generate the measurements required to support both (PHA and CST) studies. These plans, which are identified in the discussion that follows, were prepared to support the overall Task Technical and QA plan [2] and the analytical study plan [6]. The results of these measurements (both composition and properties) are presented in this section.

\section{Chemical Compositions}

Table 2 provides the target oxide compositions for each of the PHA glasses. See Attachment I of [3] for details on the development of these target compositions. The Phase 3 glasses, as previously stated, appear as pha01 through pha06 in Table 2.

Table 2: Target Oxide Compositions (in weight percents, wt\%'s) of the PHA Glasses

\begin{tabular}{|c|c|c|c|c|c|c|c|c|c|c|c|c|c|c|c|c|}
\hline & & & & & ss & & & & & & & & & & & \\
\hline Sludge & MST & PHA & Frit 202 & ID & $\mathbf{A l}_{2} \mathbf{O}_{3}$ & $\mathrm{~B}_{2} \mathrm{O}_{3}$ & $\mathbf{B a O}$ & $\mathrm{CaO}$ & $\mathrm{Cr}_{2} \mathrm{O}_{3}$ & $\mathrm{CuO}$ & $\mathrm{Fe}_{2} \mathrm{O}_{3}$ & $\mathbf{K}_{2} \mathbf{O}$ & $\mathbf{L i}_{2} \mathbf{O}$ & $\mathrm{MgO}$ & $\mathrm{MnO}$ & $\mathrm{Na}_{2} \mathrm{O}$ \\
\hline 22 & 1.250 & 7 & 69.750 & pha01 & 2.540 & 7.974 & 0.084 & 0.945 & 0.106 & 0.568 & 9.899 & 3.350 & 4.785 & 1.448 & 1.727 & 7.869 \\
\hline 22 & 1.250 & 10 & 66.750 & pha02 & 2.522 & 8.803 & 0.084 & 0.941 & 0.106 & 0.791 & 9.897 & 4.730 & 4.579 & 1.389 & 1.727 & 017 \\
\hline 22 & 1.250 & 13 & 63.750 & pha03 & 2.504 & 9.632 & 0.084 & 0.936 & 0.106 & 1.014 & 9.894 & 6.110 & 4.373 & 1.329 & 1.727 & .165 \\
\hline 22 & 2.500 & 7 & 68.500 & pha04 & 2.532 & 7.876 & 0.084 & 0.943 & 0.106 & 0.568 & 9.898 & 3.350 & 4.699 & 1.423 & 1.727 & .944 \\
\hline 22 & 2.500 & 10 & 65.500 & pha05 & 2.514 & 8.705 & 0.084 & 0.939 & 0.106 & 0.791 & 9.896 & 4.730 & 4.493 & 1.364 & 1.727 & 8.092 \\
\hline 22 & 2.500 & 13 & 62.500 & pha06 & 2.496 & 9.534 & 0.084 & 0.934 & 0.106 & 1.014 & 9.893 & 6.110 & 4.288 & 1.304 & 1.727 & 8.240 \\
\hline 26 & 1.250 & 7 & 65.750 & pha07 & 2.901 & 7.660 & 0.099 & 1.092 & 0.125 & 0.576 & 11.685 & 3.365 & 4.510 & 1.381 & 2.041 & 8.116 \\
\hline 26 & 1.250 & 10 & 62.750 & pha08 & 2.883 & 8.488 & 0.099 & 1.088 & 0.125 & 0.800 & 11.683 & 4.745 & 4.305 & 1.322 & 2.041 & 8.264 \\
\hline 26 & 1.250 & 13 & 59.750 & pha09 & 2.865 & 9.317 & 0.099 & 1.083 & 0. & 1.023 & 81 & 6.125 & 4.099 & 1.262 & 2.041 & 8.412 \\
\hline 26 & 2.500 & 7 & 64.500 & pha10 & 2.894 & 7.561 & 0.099 & 1.090 & 0.125 & 0.576 & 11.684 & 3.365 & 4.425 & 1.356 & 2.041 & 8.191 \\
\hline 26 & 2.500 & 10 & 61.500 & phal1 & 2.876 & 8.390 & 0.099 & 1.086 & 0.125 & 0.800 & 11.682 & 4.745 & 4.219 & 1.297 & 2.041 & 8.339 \\
\hline 26 & 2.500 & 13 & 58.500 & phal2 & 2.858 & 9.219 & 0.099 & 1.081 & 0.125 & 1.023 & 11.680 & 6.125 & 4.013 & 1.237 & 2.041 & 8.487 \\
\hline 30 & 1.250 & 7 & 61.750 & pha13 & 3.263 & 7.345 & 0.114 & 1.239 & 0.144 & 0.585 & 13.472 & 3.380 & 4.236 & 1.314 & 2.355 & 8.363 \\
\hline 30 & 1.250 & 10 & 58.750 & pha14 & 3.245 & 8.174 & 0.114 & 1.234 & 0.144 & 0.808 & 13.470 & 4.760 & 4.030 & 1.255 & 2.355 & 8.511 \\
\hline 30 & 1.250 & 13 & 55.750 & phal5 & 3.227 & 9.003 & 0.114 & 1.230 & 0.144 & 1.031 & 13.467 & 6.140 & 3.824 & 1.195 & 2.355 & 8.659 \\
\hline 30 & 2.500 & 7 & 60.500 & phal6 & 3.256 & 7.246 & 0.114 & 1.237 & 0.144 & 0.585 & 13.471 & 3.379 & 4.150 & 1.289 & 2.355 & 8.438 \\
\hline 30 & 2.500 & 10 & 57.500 & pha17 & 3.238 & 8.075 & 0.114 & 1.233 & 0.144 & 0.808 & 13.469 & 4.759 & 3.945 & 1.230 & 2.355 & 8.586 \\
\hline 30 & 2.500 & 13 & 54.500 & pha18 & 3.220 & 8.904 & 0.114 & 1.228 & 0.144 & 1.031 & 13.466 & 6.139 & 3.739 & 1.170 & 2.355 & 8.734 \\
\hline
\end{tabular}


Table 2: Target Oxide Compositions (in weight percents, wt\%'s) of the PHA Glasses (continued)

\begin{tabular}{|c|c|c|c|c|c|c|c|c|c|c|c|c|c|c|c|}
\hline & & & & Glass & & & & & & & & & & & \\
\hline $\begin{array}{c}\text { Sludge } \\
22\end{array}$ & $\begin{array}{l}\text { MST } \\
1.250\end{array}$ & $\begin{array}{c}\text { PHA } \\
7\end{array}$ & Frit 202 & ID & $\begin{array}{c}\text { NiO } \\
0.930\end{array}$ & $\begin{array}{l}\mathbf{P}_{2} \mathbf{O}_{\mathbf{5}} \\
0.030\end{array}$ & $\begin{array}{c}\text { PbO } \\
0.096\end{array}$ & $\begin{array}{c}\mathrm{SiO}_{2} \\
53.684\end{array}$ & $\begin{array}{l}\mathrm{TiO}_{2} \\
1.128\end{array}$ & $\begin{array}{l}\mathrm{U}_{3} \mathrm{O}_{2} \\
2.003\end{array}$ & $\begin{array}{c}\mathrm{ZnO} \\
0.086\end{array}$ & $\mathrm{ZrO}_{2}$ & $\begin{array}{c}F \\
0.032\end{array}$ & $\begin{array}{c}\mathrm{Cl}^{-} \\
0.240\end{array}$ & $\begin{array}{l}\left(\mathrm{SO}_{4}\right)^{\circ} \\
0.173\end{array}$ \\
\hline $\begin{array}{l}22 \\
22\end{array}$ & 1.250 & 10 & 66. & pha02 & 0.930 & 0.030 & 0.096 & 51.404 & 1.127 & 2.003 & 0.086 & 0.109 & 0.032 & 0.240 & 0.173 \\
\hline 22 & 1.250 & 13 & 63.750 & pha03 & 0.930 & 0.030 & 0.096 & 49.124 & 1.125 & 2.003 & 0.086 & 0.109 & 0.032 & 0.240 & 0.173 \\
\hline 22 & 2.500 & 7 & 68.500 & pha04 & 0.930 & 0.030 & 0.096 & 52.734 & 2.226 & 2.003 & 0.086 & 0.109 & 0.032 & 0.240 & 0.173 \\
\hline 22 & 2.500 & 10 & 65.500 & pha05 & 0.930 & 0.030 & 0.096 & 50.454 & 2.225 & 2.003 & 0.086 & 0.109 & 0.032 & 0.240 & 0.173 \\
\hline 22 & 2.500 & 13 & 62.500 & pha06 & 0.930 & 0.030 & 0.096 & 48.174 & 2.224 & 2.003 & 0.086 & 0.109 & 0.032 & 0.240 & 0.173 \\
\hline 26 & 1.250 & 7 & 65.750 & pha07 & 1.099 & 0.036 & 0.114 & 50.766 & 1.126 & 2.367 & 0.102 & 0.129 & 0.038 & 0.283 & 0.205 \\
\hline 26 & 1.250 & 10 & 62.750 & pha08 & 1.099 & 0.036 & 0.114 & 48. & 1.1 & 2.367 & 0.102 & 0.129 & 0.038 & 0.283 & 0.205 \\
\hline 26 & 1.250 & 13 & 59.750 & pha09 & 1.099 & 0.036 & 0.114 & 46.206 & 1.124 & 2.367 & 0.102 & 0.129 & 0.038 & 0.283 & 0.205 \\
\hline 26 & 2.500 & 7 & 64.500 & phalo & 1.099 & 0.036 & 0.114 & 49.816 & 2.224 & 2.367 & 0.102 & 0.129 & 0.038 & 0.283 & 0.205 \\
\hline 26 & 2.500 & 10 & & phall & 1.099 & 0.036 & 0.114 & 47.536 & 2.223 & 2.367 & 0.102 & 0.129 & 0.038 & 0.283 & 0.205 \\
\hline 26 & 2.500 & 13 & 58.500 & pha12 & 1.099 & 0.036 & 0.114 & 45.256 & 2.222 & 2.367 & 0.102 & 0.129 & 0.038 & 0.283 & 0.205 \\
\hline 30 & 1.250 & 7 & 61.750 & pha13 & 1.268 & 0.041 & 0.132 & 47.849 & 1.125 & 2.731 & 0.118 & 0.149 & 0.043 & 0.327 & 0.236 \\
\hline 30 & 1.250 & 10 & 58.750 & pha14 & 1.268 & 0.041 & 0.132 & 45.569 & 1.123 & 2.731 & 0.118 & 0.149 & 0.043 & 0.327 & 0.236 \\
\hline 30 & 1.250 & 13 & 55.750 & pha1s & 1.268 & 0.041 & 0.132 & 43.289 & 1.122 & 2.731 & 0.118 & 0.149 & 0.043 & 0.327 & 0.236 \\
\hline 30 & 2.500 & 7 & 60.500 & pha16 & 1.268 & 0.041 & 0.132 & 46.899 & 2.223 & 2.731 & 0.118 & 0.149 & 0.043 & 0.327 & 0.236 \\
\hline 30 & 2.500 & 10 & 57.500 & pha17 & 1.268 & 0.041 & 0.132 & 44.619 & 2.221 & 2.731 & 0.118 & 0.149 & 0.043 & 0.327 & 0.236 \\
\hline & 2.500 & 13 & 54.500 & phal 8 & 1.268 & 0.041 & 0.132 & 42.339 & 2.220 & 2.731 & 0.118 & 0.149 & 0.043 & 0.327 & 0.236 \\
\hline
\end{tabular}

Predictions for the properties of interest generated for these target compositions by the models utilized by the Defense Waste Processing Facility (DWPF) are also included in the discussion provided in Attachment I of [3]. These properties, for a given composition, relate to its processability and its product quality. For a given composition, acceptable property characteristics and reliable property predictions (using the current DWPF models) are of interest. Comparisons between property predictions and property measurements are provided for these Phase 3 PHA glasses in the discussion that follows.

Glasses were batched and fabricated to the target compositions corresponding to rows pha01 though pha06 of Table 2. In addition to the Phase 3 glasses (both PHA and CST), a standard glass (Batch 1) and a standard uranium-bearing glass were included in the planning of these analyses (for possible bias correction). An analytical plan (in the form of a memorandum) was provided to assist the SRTCMobile Laboratory (SRTC-ML) in conducting these analyses (see Attachment I of [5]). Due to an equipment problem at that laboratory, the samples were subsequently submitted to the Analytical Development Section (ADS) of SRTC for analysis.

Glasses were batched using the appropriate combinations of Purex sludge, glass formers, PHA, and MST. The simulated Purex sludge was batched from dry chemicals and has an oxide composition provided in Table 3 of Attachment I of [3]. PHA was batched from chemicals and has an oxide composition provided in Table 2 of Attachment I of [3]. A basic MST solution was obtained from D. Hobbs. This material was washed and then dried. The composition of MST was determined by the SRTC-ML and is presented in Table 1 of Attachment I of [3]. Frit 202, Lot 14 was obtained from the DWPF. The Frit 202 composition is given in Table 7 of Attachment I in [3].

For each glass, the combined powders ( 120 grams) were added to a $250 \mathrm{~mL}$ Pt-Au crucible and placed in a calibrated furnace, heated to $1150^{\circ} \mathrm{C}$ at a rate of $10^{\circ} \mathrm{C} /$ minute, and then held for four hours at $1150^{\circ} \mathrm{C}$. The crucible was then removed and the glass immediately poured onto a clean stainless steel plate.

Tables A.1 and A.2 in the Appendix provide the composition measurements obtained by ADS following an analytical plan similar to that provided in Attachment $I$ of this report. ${ }^{1}$ Two dissolutions (microwave and peroxide fusion) were used to generate these composition measurements. Table A.1 provides the peroxide fusion (pf) results and Table A.2 the microwave (MW) results. Calcium and silicon cation concentrations were measured using both preparation methods.

1 ADS LIMS numbers were assigned to the dissolved samples. 
Exhibit A.1 in the Appendix provides a plot of the measurements by glass sample id by oxide. The patterns presented by the measurements for glass pha01 are of concern. The measurements corresponding to one of the two microwave dissolutions of this glass have been labeled in these plots as a "z." Note that almost all of the measurements derived from the microwave dissolution method reveal a discrepancy between the results from the duplicate preparations by this method. The results represented by the " $z$ " are outliers (perhaps due to a incomplete dissolution of the glass sample) and will not be included in the analyses that follow.

A review of the results from the standards was conducted for insight into the possibility that the ICP calibration contributes (in a systematic way) to the variation seen in the oxide measurements for the Phase 3 glasses. Exhibits A.2 and A.3 in the Appendix provide plots of the oxide measurements per analytical block by oxide by dissolution method. Table 3 provides the average measured composition for the two types of standards included in this analytical plan by analytical block. The reference values for the standards are also provided in this table.

Table 3: Measurements from Glass Standards

\begin{tabular}{|c|c|c|c|c|c|c|}
\hline & \multirow{2}{*}{\multicolumn{2}{|c|}{$\frac{\text { std (Batch 1) }}{\text { Analytical Block }}$}} & & \multicolumn{3}{|c|}{ Ustd (Uranium-bearing Standard) } \\
\hline & & & & Analy & lock & \\
\hline & 1 & 2 & Reference & 1 & 2 & Reference \\
\hline Oxide & 3 obs & 3 obs & Value & 2 obs & 2 obs & Value \\
\hline $\mathrm{Al}_{2} \mathrm{O}_{3}$ & 4.935 & 4.860 & 4.877 & 4.121 & 4.087 & 4.100 \\
\hline $\mathbf{B}_{2} \mathbf{O}_{3}$ & 7.627 & 7.967 & 7.777 & 8.818 & 9.362 & 9.209 \\
\hline $\mathrm{CaO}$ (pf) & 1.237 & 1.231 & 1.220 & 1.337 & 1.326 & 1.301 \\
\hline $\mathrm{CaO}$ (MW) & 1.231 & 1.287 & 1.220 & 1.355 & 1.416 & 1.301 \\
\hline $\mathrm{CaO}$ (avg) & 1.234 & 1.259 & 1.220 & 1.346 & 1.371 & 1.301 \\
\hline $\mathrm{Cr}_{2} \mathrm{O}_{3}$ & 0.112 & 0.112 & 0.107 & 0.270 & 0.272 & 0.000 \\
\hline $\mathrm{CuO}$ & 0.402 & 0.399 & 0.399 & 0.020 & 0.021 & 0.000 \\
\hline $\mathrm{Fe}_{2} \mathrm{O}_{3}$ & 13.579 & 13.227 & 12.839 & 14.156 & 13.883 & 13.196 \\
\hline $\mathbf{K}_{2} \mathbf{O}$ & 3.196 & 3.195 & 3.327 & 2.892 & 2.938 & 2.999 \\
\hline $\mathbf{L}_{2} \mathbf{O}$ & 4.514 & 4.515 & 4.429 & 3.122 & 3.128 & 3.057 \\
\hline MgO & 1.429 & 1.432 & 1.419 & 1.197 & 1.207 & 1.210 \\
\hline Mno & 1.729 & 1.739 & 1.726 & 2.820 & 2.849 & 2.892 \\
\hline $\mathrm{Na}_{2} \mathrm{O}$ & 9.240 & 9.142 & 9.003 & 12.188 & 12.077 & 11.795 \\
\hline $\mathrm{NiO}$ & 0.800 & 0.780 & 0.751 & 1.161 & 1.129 & 1.120 \\
\hline $\mathrm{SiO}_{2}$ (pf) & 48.207 & 47.709 & 50.220 & 44.711 & 43.969 & 45.353 \\
\hline $\mathrm{SiO}_{2}(\mathrm{MW})$ & 51.425 & 52.137 & 50.220 & 45.150 & 46.382 & 45.353 \\
\hline $\mathrm{SiO}_{2}$ (avg) & 49.816 & 49.923 & 50.220 & 44.930 & 45.176 & 45.353 \\
\hline $\mathrm{TiO}_{2}$ & 0.710 & 0.699 & 0.677 & 1.040 & 1.025 & 1.049 \\
\hline $\mathrm{U}_{3} \mathrm{O}_{8}$ & 0.349 & 0.340 & 0.000 & 2.639 & 2.452 & 2.406 \\
\hline $\mathrm{ZrO}_{2}$ & 0.177 & 0.137 & 0.098 & 0.022 & 0.022 & 0.000 \\
\hline Sum of Oxides & 99.919 & 99.796 & 98.869 & 100.774 & 101.113 & 99.687 \\
\hline
\end{tabular}

The analytical results from the Batch 1 samples were used to bias-correct for a possible ICP calibration effect ( $a$ block effect) in the other measurements. ${ }^{2}$ This was accomplished for each oxide in turn by taking the original oxide measurement, noting its block, and then multiplying the measurement by the ratio of the corresponding reference value for Batch 1 divided by the average oxide measurement for Batch 1 in that block. The calcium and silicon values for each dissolution method were adjusted via this process. This approach was used to bias-correct the composition measurements of the Phase 3 and standard glasses.

Exhibit A.4 in the Appendix provides plots of these measurements for each oxide over all of the glasses (including the standards), and Table 4 provides summary information for these measurements. The sums of oxides for the target, measured, and measured bias-corrected (bc) compositions are also provided. A review of these sums shows that they are all within the interval of 95 to 105 weight

2 Bias corrections of this type have been advantageous (see for example "A Statistical Review of Data from the SRTC Mobile Laboratory," WSRC-RP-98-00430, Revision 0, June 15, 1998) but not always. In some instances, bias correction does not improve the accuracy of the results. Measurements are bias-corrected in this report, and bias-corrected values are considered in the comparisons that follow. Conclusions, developed from these comparisons, that are insensitive to the way the glass compositions are represented (target, measured, or bias-corrected) demonstrate robustness to which representation might be nearer the true composition for each glass. 
percent with the lowest value being $96.5 \mathrm{wt} \%$ for the bias-corrected composition of pha05 and the largest, $100.9 \mathrm{wt} \%$, for the measured composition of the uranium-bearing standard glass. Another observation from this exhibit and table is the closeness of the $\mathrm{TiO}_{2}$ measurements to their respective targets for these PHA glasses. A problem was seen in Phases 1 [3] and 2 [7]. Namely, the $\mathrm{TiO}_{2}$ measurements for the PHA glasses fell short of their respective target values even though the measurements for the standards compared very favorably to their targets. This behavior prompted a reevaluation of a source of $\mathrm{TiO}_{2}$, the MST. A subsequent analysis of MST revealed a larger than expected moisture content. However, as discussed in [3], glasses for Phases 1 and 2 were batched and fabricated prior to this discovery. Batching formulations were subsequently modified to account for the additional loss that would be expected for this situation. Glasses for Phase 3 were and glasses for Phase 4 are to be batched in a manner fully accounting for the loss of the additional moisture. In addition, Phase 4 is to include selected glasses from Phases 1 and 2 that are to be re-batched using the new formulations. This will provide better coverage of the higher MST loadings for these phases of the CST study. Note that the results seen in Phase 3 indicate that the targeted MST loadings were achieved for the glasses of this phase.

Table 4: Target, Measured, and Bias-Corrected Compositions (in wt\%) for the PHA Phase 3 Glasses

\begin{tabular}{|c|c|c|c|c|c|c|c|c|c|}
\hline $\begin{array}{c}\mathrm{Al}_{2} \mathrm{O}_{3} \\
\mathrm{~B}_{2} \mathrm{O}_{3} \\
\mathrm{CaO} \\
\mathrm{Cr}_{2} \mathrm{O}_{3} \\
\mathrm{CuO} \\
\mathrm{Fe}_{2} \mathrm{O}_{3} \\
\mathrm{~K}_{2} \mathrm{O} \\
\mathrm{Ll}_{2} \mathrm{O} \\
\mathrm{MgO} \\
\mathrm{MnO} \\
\mathrm{Na} \mathrm{O}_{2} \mathrm{O} \\
\mathrm{NIO} \\
\mathrm{SIO}_{2} \\
\mathrm{TlO}_{2} \\
\mathrm{U}_{3} \mathrm{O}_{3} \\
\mathrm{ZrO}_{2} \\
\text { Sum of Oxddes }\end{array}$ & $\begin{array}{c}\text { Target } \\
4.877 \\
7.777 \\
1.220 \\
0.107 \\
0.399 \\
12.839 \\
3.327 \\
4.429 \\
1.419 \\
1.726 \\
9.003 \\
0.751 \\
50.220 \\
0.677 \\
0.000 \\
0.098 \\
98.869 \\
\end{array}$ & $\begin{array}{c}\text { Batch I } \\
\\
\text { Measured } \\
4.898 \\
7.797 \\
1.246 \\
0.112 \\
0.401 \\
13.403 \\
3.196 \\
4.514 \\
1.430 \\
1.734 \\
9.191 \\
0.790 \\
49.869 \\
0.704 \\
0.344 \\
0.157 \\
99.857 \\
\end{array}$ & $\begin{array}{c}\text { Measured } \\
\text { Blas-cor. } \\
4.877 \\
7.777 \\
1.220 \\
0.107 \\
0.399 \\
12.839 \\
3.327 \\
4.429 \\
1.419 \\
1.726 \\
9.003 \\
0.751 \\
50.220 \\
0.677 \\
0.344 \\
0.098 \\
99.284 \\
\end{array}$ & $\begin{array}{c}\text { Target } \\
4.100 \\
9.209 \\
1.301 \\
0.000 \\
0.000 \\
13.196 \\
2.999 \\
3.057 \\
1.210 \\
2.892 \\
11.795 \\
1.120 \\
45.353 \\
1.049 \\
2.406 \\
0.000 \\
99.687 \\
\end{array}$ & $\begin{array}{c}\text { Mensured } \\
4.104 \\
9.090 \\
1.358 \\
0.271 \\
0.020 \\
14.019 \\
2.915 \\
3.125 \\
1.202 \\
2.835 \\
12.132 \\
1.145 \\
45.053 \\
1.033 \\
2.545 \\
0.022 \\
100.943 \\
\end{array}$ & $\begin{array}{c}\text { Blas-cor. } \\
4.086 \\
9.065 \\
1.329 \\
0.258 \\
0.020 \\
13.430 \\
3.035 \\
3.066 \\
1.193 \\
2.822 \\
11.885 \\
1.089 \\
45.408 \\
0.992 \\
2.545 \\
0.014 \\
100.311 \\
\end{array}$ & $\begin{array}{c}\text { Target } \\
2.540 \\
7.974 \\
0.945 \\
0.106 \\
0.568 \\
9.899 \\
3.350 \\
4.785 \\
1.448 \\
1.727 \\
7.869 \\
0.930 \\
53.684 \\
1.128 \\
2.003 \\
0.109 \\
99.065 \\
\end{array}$ & $\begin{array}{c}\text { pha0l } \\
\text { Messured } \\
2.868 \\
9.171 \\
1.041 \\
0.178 \\
0.580 \\
9.970 \\
2.973 \\
4.751 \\
1.464 \\
2.065 \\
8.873 \\
0.949 \\
52.702 \\
1.160 \\
1.542 \\
0.160 \\
99.093 \\
\end{array}$ & $\begin{array}{c}\text { Measured } \\
\text { Blas-cor. } \\
2.856 \\
9.147 \\
1.003 \\
0.170 \\
0.578 \\
9.550 \\
3.095 \\
4.661 \\
1.453 \\
2.056 \\
8.692 \\
0.902 \\
51.831 \\
1.115 \\
1.542 \\
0.101 \\
98.689 \\
\end{array}$ \\
\hline $\begin{array}{c}\mathrm{Al}_{2} \mathrm{O}_{3} \\
\mathrm{~B}_{2} \mathrm{O}_{3} \\
\mathrm{CaO} \\
\mathrm{Cr}_{2} \mathrm{O}_{3} \\
\mathrm{CuO} \\
\mathrm{Fe}_{2} \mathrm{O}_{3} \\
\mathrm{~K}_{2} \mathrm{O} \\
\mathrm{Li}_{2} \mathrm{O} \\
\mathrm{MgO} \\
\mathrm{MnO} \\
\mathrm{Na}_{2} \mathrm{O} \\
\mathrm{NiO} \\
\mathrm{SiO}_{2} \\
\mathrm{TiO} \mathrm{O}_{2} \\
\mathrm{U}_{3} \mathrm{O}_{\mathbf{2}} \\
\mathrm{ZrO}_{2} \\
\text { Sum of Oxddes }\end{array}$ & $\begin{array}{c}\text { Target } \\
2.522 \\
8.803 \\
0.941 \\
0.106 \\
0.791 \\
9.897 \\
4.730 \\
4.579 \\
1.389 \\
1.727 \\
8.017 \\
0.930 \\
51.404 \\
1.127 \\
2.003 \\
0.109 \\
99.075\end{array}$ & $\begin{array}{c}\text { pha02 } \\
\text { Measured } \\
2.718 \\
8.523 \\
1.009 \\
0.169 \\
0.680 \\
9.859 \\
3.663 \\
4.679 \\
1.387 \\
1.999 \\
8.249 \\
0.924 \\
51.174 \\
1.170 \\
1.659 \\
0.153 \\
98.088\end{array}$ & $\begin{array}{c}\text { Messured } \\
\text { Bigs-cor. } \\
2.707 \\
8.497 \\
0.987 \\
0.161 \\
0.677 \\
9.445 \\
3.813 \\
4.591 \\
1.376 \\
1.990 \\
8.081 \\
0.878 \\
51.557 \\
1.124 \\
1.659 \\
0.097 \\
97.713\end{array}$ & $\begin{array}{c}\text { Target } \\
2.504 \\
9.632 \\
0.936 \\
0.106 \\
1.014 \\
9.894 \\
6.110 \\
4.373 \\
1.329 \\
1.727 \\
8.165 \\
0.930 \\
49.124 \\
1.125 \\
2.003 \\
0.109 \\
99.081\end{array}$ & $\begin{array}{c}\text { pha03 } \\
\text { Measured } \\
2.542 \\
9.368 \\
0.941 \\
0.172 \\
1.009 \\
9.995 \\
5.606 \\
4.458 \\
1.358 \\
1.699 \\
8.181 \\
0.851 \\
48.797 \\
1.168 \\
2.760 \\
0.223 \\
99.201\end{array}$ & $\begin{array}{c}\text { Measured } \\
\text { Bias-cor. } \\
2.531 \\
9.341 \\
0.921 \\
0.164 \\
1.004 \\
9.575 \\
5.836 \\
4.374 \\
1.347 \\
1.691 \\
8.014 \\
0.809 \\
49.167 \\
1.123 \\
2.760 \\
0.135 \\
98.865\end{array}$ & $\begin{array}{c}\text { Target } \\
2.532 \\
7.876 \\
0.943 \\
0.106 \\
0.568 \\
9.898 \\
3.350 \\
4.699 \\
1.423 \\
1.727 \\
7.944 \\
0.930 \\
52.734 \\
2.226 \\
2.003 \\
0.109 \\
99.068\end{array}$ & $\begin{array}{c}\text { Measured } \\
2.517 \\
8.901 \\
0.953 \\
0.137 \\
0.565 \\
8.351 \\
3.099 \\
4.936 \\
1.475 \\
1.794 \\
8.401 \\
0.828 \\
55.094 \\
2.373 \\
1.081 \\
0.135 \\
100.714\end{array}$ & $\begin{array}{c}\text { Measured } \\
\text { Bias-cor. } \\
2.507 \\
8.875 \\
0.932 \\
0.131 \\
0.563 \\
8.000 \\
3.226 \\
4.843 \\
1.464 \\
1.786 \\
8.230 \\
0.787 \\
55.471 \\
2.280 \\
1.081 \\
0.086 \\
100.334\end{array}$ \\
\hline
\end{tabular}


Table 4: Target, Measured, and Bias-Corrected Compositions (in wt\%) for the PHA Phase 3 Glasses (continued)

\begin{tabular}{|c|c|c|c|c|c|c|c|}
\hline $\begin{array}{c}\mathrm{Al}_{2} \mathrm{O}_{3} \\
\mathrm{~B}_{2} \mathrm{O}_{3} \\
\mathrm{CaO} \\
\mathrm{Cr}_{2} \mathrm{O}_{3} \\
\mathrm{CuO} \\
\mathrm{Fe}_{2} \mathrm{O}_{3} \\
\mathrm{~K}_{2} \mathrm{O} \\
\mathrm{L}_{2} \mathrm{O} \\
\mathrm{MgO} \\
\mathrm{MnO} \\
\mathrm{Na}_{2} \mathrm{O} \\
\mathrm{NiO} \\
\mathrm{SiO}_{2} \\
\mathrm{TiO}_{2} \\
\mathrm{U}_{3} \mathrm{O}_{3} \\
\mathrm{ZrO}_{2} \\
\text { Sum of Oxides }\end{array}$ & $\begin{array}{c}\text { Target } \\
2.514 \\
8.705 \\
0.939 \\
0.106 \\
0.791 \\
9.896 \\
4.730 \\
4.493 \\
1.364 \\
1.727 \\
8.092 \\
0.930 \\
50.454 \\
2.225 \\
2.003 \\
0.109 \\
99.078 \\
\end{array}$ & $\begin{array}{c}\text { pha05 } \\
\text { Measured } \\
2.508 \\
7.974 \\
0.920 \\
0.150 \\
0.722 \\
9.975 \\
4.309 \\
4.596 \\
1.386 \\
1.629 \\
8.054 \\
0.846 \\
48.402 \\
2.296 \\
2.869 \\
0.153 \\
96.861 \\
\end{array}$ & $\begin{array}{c}\text { Measured } \\
\text { Blas-cor. } \\
2.497 \\
7.953 \\
0.900 \\
0.143 \\
0.719 \\
9.555 \\
4.485 \\
4.509 \\
1.375 \\
1.621 \\
7.889 \\
0.804 \\
48.834 \\
2.206 \\
2.869 \\
0.096 \\
96.532 \\
\end{array}$ & $\begin{array}{c}\text { Target } \\
2.496 \\
9.534 \\
0.934 \\
0.106 \\
1.014 \\
9.893 \\
6.110 \\
4.288 \\
1.304 \\
1.727 \\
8.240 \\
0.930 \\
48.174 \\
2.224 \\
2.003 \\
0.109 \\
99.086 \\
\end{array}$ & $\begin{array}{c}\text { phra06 } \\
\text { Measured } \\
2.602 \\
9.196 \\
0.972 \\
0.153 \\
0.953 \\
10.019 \\
5.757 \\
4.353 \\
1.316 \\
1.789 \\
8.270 \\
0.874 \\
48.432 \\
2.309 \\
2.441 \\
0.160 \\
99.670 \\
\end{array}$ & $\begin{array}{c}\text { Measured } \\
\text { Blas-cor. } \\
2.591 \\
9.173 \\
0.951 \\
0.146 \\
0.949 \\
9.598 \\
5.994 \\
4.271 \\
1.305 \\
1.780 \\
8.101 \\
0.831 \\
48.793 \\
2.219 \\
2.441 \\
0.101 \\
99.318 \\
\end{array}$ & \\
\hline
\end{tabular}

\section{PCT Results}

The six PHA glasses making up Phase 3, after being batched and fabricated, were subjected to the 7day Product Consistency Test (PCT) as an assessment of their durabilities [4]. More specifically, Method A of the PCT (ASTM C1285) was used for these measurements. Since durability is the critical product quality metric for vitrified nuclear waste, a review of the PCTs for these glasses was seen as a prerequisite for additional testing of these glasses. The PCTs were to be conducted in triplicate for the Phase 3 glasses. In addition, PCTs were also conducted in triplicate for samples of the Environmental Assessment (EA) glass, the ARM glass, and a blank (ASTM Type I water). An analytical plan supporting these tests was provided in the form of a memorandum (see Attachment II of [5]). This plan was intended to provide assistance to the SRTC-ML in measuring the compositions of the solutions resulting from these PCTs. However, due to equipment problems, the SRTC-ML was unable to conduct these analyses. The Analytical Development Section (ADS) of SRTC used a modified version of the analytical plan (ADS LIMS numbers were assigned to the blind samples) to perform these analyses. Of primary interest were the concentrations (in parts per million, ppm) of boron (B), lithium ( $\mathrm{Li})$, sodium $(\mathrm{Na})$, and silicon $(\mathrm{Si})$. Samples of a multi-element solution standard were also included in this analytical plan (as a check on the accuracy of the Inductively Coupled Plasma (ICP) - Emission Spectrometer used for these measurements).

The results from these tests are given in Table A.3 of the Appendix. Any measurement determined to be below detection was replaced by its detection limit in subsequent analyses. PCT leachate concentrations are typically normalized using the cation composition (expressed as a weight percent) in the glass to obtain a grams-per-liter $(\mathrm{g} / \mathrm{L})$ leachate concentration. The normalization of the PCTs is usually conducted using the measured compositions of the glasses. This is the preferred normalization process for the PCTs. For completeness, the target cation compositions will also be used to conduct this normalization.

As is the usual convention, the common logarithm of the normalized PCT (normalized leachate, NL) for each element of interest will be determined and used for comparisons. To accomplish this computation, one must

1. Determine the common logarithm of the elemental parts per million (ppm) leachate concentration for each of the triplicates and each of the elements of interest (these values are provided in Table A.3 of the Appendix),

2. Average the common logarithms over the triplicates for each element of interest, and then 
Normalizing Using Measured Composition (preferred method)

3. Subtract a quantity equal to 1 plus the common logarithm of the average cation measured concentration (expressed as a weight percent of the glass) from the average computed in step 2.

Or

\section{Normalizing Using Target Composition}

3. Subtract a quantity equal to 1 plus the common logarithm of the target cation concentration (expressed as a weight percent of the glass) from the average computed in step 2 .

As a preliminary step to completing these normalizations of the PCTs, a review of the data was conducted. Exhibit A.5 in the Appendix provides plots of the leachate concentrations by sample id and by element with and without the EA and the blank samples. No problems are seen in these data, in that the results are reasonably consistent across all Phase 3 and standard glasses. Table 5 provides a look at the results from the three analyses of the multi-element standard solution that were included in each block of the analytical plan. These results also indicate consistent and reasonably accurate results from these analyses.

Table 5: Measurements of Standard Solution

\begin{tabular}{|c|c|c|c|c|c|}
\hline Block & Sequence & $\mathrm{B}$ (ppm) & Si (ppm) & $\mathrm{Na}(\mathrm{ppm})$ & Li (ppm) \\
\hline 1 & 1 & 19.5 & 48.9 & 82.7 & 9.9 \\
\hline 1 & 1 & 19.8 & 49.5 & 84.2 & 10.1 \\
\hline 1 & 1 & 19.7 & 49.0 & 83.5 & 10.0 \\
\hline Block I & average & 19.6 & 49.1 & 83.5 & 10.0 \\
\hline 2 & 2 & 19.4 & 49.6 & 81.8 & 9.7 \\
\hline 2 & 2 & 19.5 & 49.3 & 81.6 & 9.7 \\
\hline 3 & 2 & 19.4 & 49.2 & 81.4 & 9.7 \\
\hline Block 2 & average & 19.4 & 49.4 & 81.6 & 9.7 \\
\hline 3 & 3 & 19.1 & 48.8 & 80.6 & 9.5 \\
\hline 3 & 3 & 19.3 & 49.0 & 81.5 & 9.6 \\
\hline 3 & 3 & 19.3 & 49.3 & 82.1 & 9.7 \\
\hline Block 3 & average & 19.2 & 49.0 & 81.4 & 9.6 \\
\hline 4 & 4 & 19.2 & 49.0 & 81.8 & 9.7 \\
\hline 4 & 4 & 19.4 & 49.1 & 82.4 & 9.8 \\
\hline 4 & 4 & 19.3 & 49.1 & 82.2 & 9.7 \\
\hline Block 4 & average & 19.3 & 49.1 & 82.1 & 9.7 \\
\hline 5 & 5 & 19.7 & 49.0 & 83.4 & 10.0 \\
\hline 5 & 5 & 19.8 & 49.0 & 83.7 & 10.1 \\
\hline 5 & 5 & 19.8 & 49.0 & 83.7 & 10.1 \\
\hline Block 5 & average & 19.7 & 49.0 & 83.6 & 10.0 \\
\hline 6 & 6 & 19.5 & 48.6 & 83.0 & 10.0 \\
\hline 6 & 6 & 19.6 & 48.6 & 83.3 & 10.0 \\
\hline 6 & 6 & 19.7 & 49.0 & 83.7 & 10.1 \\
\hline Block 6 & average & 19.6 & 48.7 & 83.3 & 10.0 \\
\hline Overall & average & 19.5 & 49.0 & 82.6 & 9.9 \\
\hline Reference & Value & 20 & 50 & 81 & 10 \\
\hline \% Difference & & $-2.6 \%$ & $-1.9 \%$ & $2.0 \%$ & $-1.5 \%$ \\
\hline
\end{tabular}

Table 6 provides the results from the normalization process using the information in Table 4 and Table A.3. Exhibit A.6 in the Appendix provides scatter plots for these results offering an opportunity to investigate the consistency in the leaching across the elements for the glasses of this study. This consistency is typically demonstrated by a high degree of linear correlation among the values. For the PCTs normalized using the target compositions, these correlations range from $86 \%$ (between $\mathrm{Na}$ and Si) to 97\% (between B and Na). The correlations among the PCTs normalized, using the measured compositions and the bias-corrected measurements, range from $85 \%$ (between $\mathrm{Na}$ and $\mathrm{Si}$ ) to $99 \%$ (between $\mathrm{Na}$ and $\mathrm{Li}$ ). 
Table 6: Normalized PCT

\begin{tabular}{|c|c|c|c|c|c|c|c|c|c|}
\hline $\begin{array}{c}\text { Glass ID } \\
\text { ARM } \\
\text { EA }\end{array}$ & $\begin{array}{l}\text { Composition } \\
\text { reference comp. [8] } \\
\text { reference comp. [8] }\end{array}$ & $\begin{array}{c}\log N L \\
{[B(g / L)]} \\
-0.29085 \\
1.28207\end{array}$ & $\begin{array}{c}\log N L \\
{[\mathrm{Si}(g / \mathrm{L})]} \\
-0.54854 \\
0.63353\end{array}$ & $\begin{array}{c}\log N L \\
{[\mathrm{Na}(\mathrm{g} / \mathrm{L})]} \\
-0.27396 \\
1.18838\end{array}$ & $\begin{array}{c}\log \mathrm{NL} \\
{[\mathrm{Li}(\mathrm{g} / \mathrm{L})]} \\
-0.21652 \\
1.04022\end{array}$ & $\begin{array}{c}\mathrm{NL} \\
{[\mathrm{B}(\mathrm{g} / \mathrm{L})]} \\
0.51 \\
19.15\end{array}$ & $\begin{array}{c}\mathrm{NL} \\
{[\mathrm{Si}(\mathrm{g} / \mathrm{L})]} \\
0.28 \\
4.30\end{array}$ & $\begin{array}{c}\mathrm{NL} \\
{[\mathrm{Na}(\mathrm{g} / \mathrm{L})]} \\
0.53 \\
15.43\end{array}$ & $\begin{array}{c}\mathrm{NL} \\
{[\mathrm{Li}(\mathrm{g} / \mathrm{L})]} \\
0.61 \\
10.97\end{array}$ \\
\hline \multirow{3}{*}{ pha01 } & measured & 0.16802 & -0.17747 & 0.11093 & 0.13608 & 1.47 & 0.66 & 1.29 & 1.37 \\
\hline & measured, bias-cor. & 0.16916 & -0.17023 & 0.11988 & 0.14439 & 1.48 & 0.68 & 1.32 & 1.39 \\
\hline & target & 0.22876 & -0.18548 & 0.16308 & 0.13299 & 1.69 & 0.65 & 1.46 & 1.36 \\
\hline \multirow{3}{*}{ pha02 } & measured & 0.10400 & -0.22546 & 0.06252 & 0.08270 & 1.27 & 0.60 & 1.15 & 1.21 \\
\hline & measured, bias-cor. & 0.10532 & -0.22870 & 0.07145 & 0.09095 & 1.27 & 0.59 & 1.18 & 1.23 \\
\hline & target & 0.08996 & -0.22741 & 0.07491 & 0.09208 & 1.23 & 0.59 & 1.19 & 1.24 \\
\hline \multirow{3}{*}{ pha03 } & measured & 0.24524 & -0.15256 & 0.19801 & 0.20929 & 1.76 & 0.70 & 1.58 & 1.62 \\
\hline & measured, bias-cor. & 0.24650 & -0.15584 & 0.20697 & 0.21755 & 1.76 & 0.70 & 1.61 & 1.65 \\
\hline & target & 0.23317 & -0.15546 & 0.19886 & 0.21765 & 1.71 & 0.70 & 1.58 & 1.65 \\
\hline \multirow{3}{*}{ pha04 } & measured & 0.18716 & -0.13764 & 0.15247 & 0.17857 & 1.54 & 0.73 & 1.42 & 1.51 \\
\hline & measured, bias-cor. & 0.18843 & -0.14060 & 0.16140 & 0.18683 & 1.54 & 0.72 & 1.45 & 1.54 \\
\hline & target & 0.24029 & -0.11862 & 0.17676 & 0.19994 & 1.74 & 0.76 & 1.50 & 1.58 \\
\hline \multirow{3}{*}{ pha05 } & measured & 0.11243 & -0.20595 & 0.04395 & 0.06108 & 1.30 & 0.62 & 1.11 & 1.15 \\
\hline & measured, bias-cor. & 0.11357 & -0.20981 & 0.05294 & 0.06938 & 1.30 & 0.62 & 1.13 & 1.17 \\
\hline & target & 0.07434 & -0.22399 & 0.04190 & 0.07092 & 1.19 & 0.60 & 1.10 & 1.18 \\
\hline \multirow{3}{*}{ pha06 } & measured & 0.19514 & -0.17575 & 0.15701 & 0.17256 & 1.57 & 0.67 & $1 . \overline{44}$ & 1.49 \\
\hline & measured, bias-cor. & 0.19623 & -0.17897 & 0.16598 & 0.18082 & 1.57 & 0.66 & 1.47 & 1.52 \\
\hline & target & 0.17947 & -0.17343 & 0.15859 & 0.17909 & 1.51 & 0.67 & 1.44 & 1.51 \\
\hline
\end{tabular}

As seen in Table 6, the durabilities for the PHA Phase 3 glasses are much better than that of EA. (This is indicated for each glass by its normalized leachate being much smaller than that of EA.). Figure 1 provides an opportunity for a closer look at these results using measured and bias-corrected compositions. Figure 1 is a plot of the DWPF model that relates the logarithm of the normalized PCT (in this case for $B$ ) to a linear function of a free energy of hydration term ( $\Delta G_{p}, \mathrm{kcal} / 100 \mathrm{~g}$ glass) derived from the glass (measured and bias-corrected) compositions [8]. Prediction limits (at 95\% confidence) for individual PCT results are also plotted around this linear fit. The PCT results for EA (shown as a diamond), ARM (shown as a "z"), and the PHA glasses (each shown as an " $x$ ") are presented on this plot. Note that the PHA results reveal acceptable and predictable PCTs (i.e., PCTs that are well predicted by the current DWPF durability model). Figure 2 provides a plot of the boron results based upon target compositions. Exhibit A.7 in the Appendix provides similar plots of the PHA durability measurements versus the DWPF durability models for $\mathrm{B}, \mathrm{Si}, \mathrm{Na}$, and $\mathrm{Li}$. The behavior seen in the plots for $\mathrm{Si}, \mathrm{Na}$, and $\mathrm{Li}$ is similar to that demonstrated by the $\mathrm{B}$ results: acceptable and predictable durabilities. 
Figure 1.

Log NL(B) (g/L) By del Gp

(Using Measured \& Bias-corrected and

EA and ARM reference compositions)

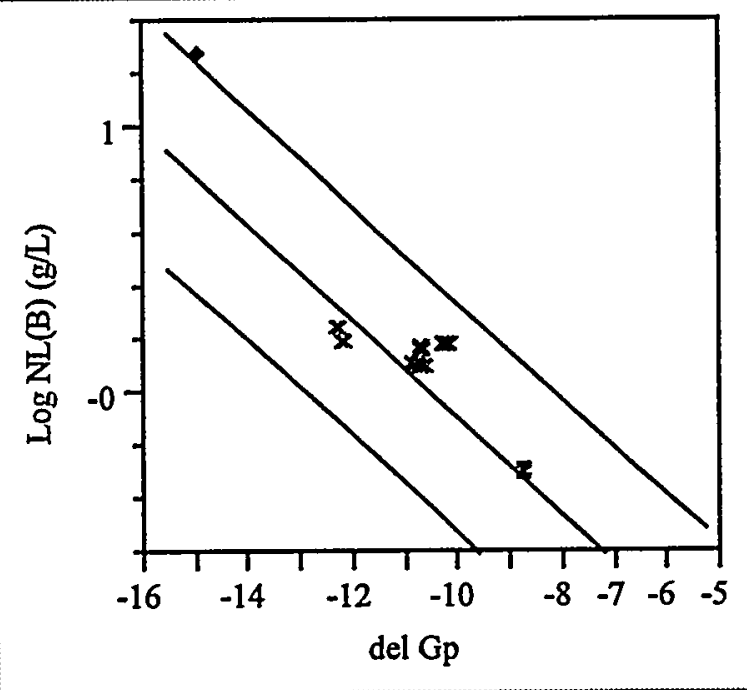

Figure 2.

$\log N L(B)(g / L)$ By del Gp

(Using PHA target compositions and EA and ARM reference compositions)

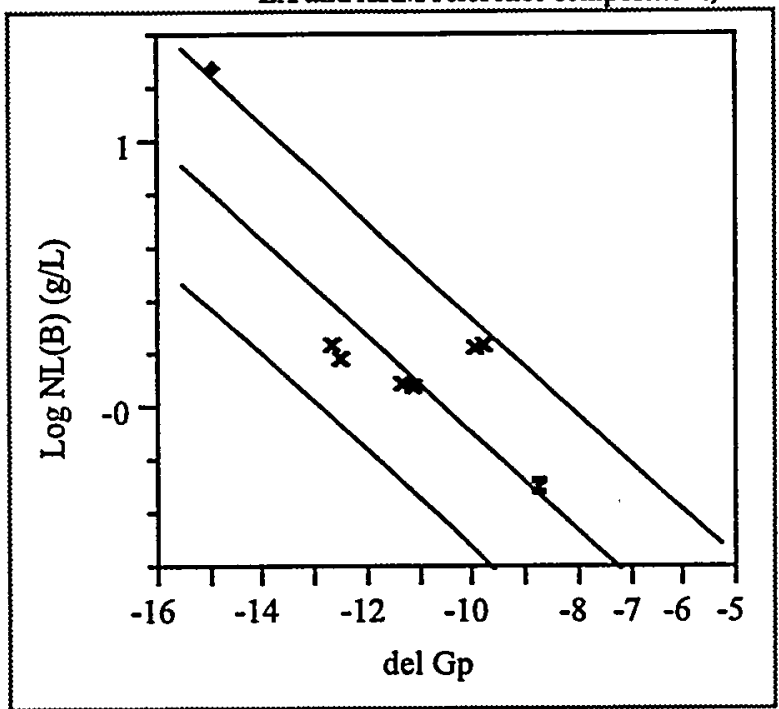

\section{Viscosity at $1150^{\circ} \mathrm{C}$}

Viscosity measurements were made on two of the six Phase 3 PHA glasses at SRTC using a Harrop, high-temperature viscometer [9]. The viscosity (in Poise) of each of these glasses at $1150^{\circ} \mathrm{C}$ is to be estimated from a Fulcher equation fitted to a set of viscosity measurements taken over an appropriate range of temperatures. The functional form of the (three-parameter) Fulcher equation (expressed in Poise) used to fit these data is given by equation (1):

$$
\ln \hat{\eta}=A+\frac{B}{(T-C)}
$$

where $A, B$, and $C$ represent the parameters of the model that are to be determined from the available measurements (represented by $\eta$, expressed in Poise) at various temperatures (represented by $T$ ). The fitted model is then used to predict the viscosity of the given glass at $1150^{\circ} \mathrm{C}$.

Although no definitive error analysis has been completed on the use of the Harrop viscometer, SRTC has conducted several sets of viscosity measurements using this viscometer with good results [10]. Two crucible/spindle sets were used in conducting these measurements, which were sequenced according to the plan provided in Attachment IV of [7]. This plan covered glasses from Phases 2 through 4 for both CST and PHA and called for these measurements to be followed by measurements of the Batch 1 standard glass with both crucible/spindle sets. Measurements of Batch 1 that were conducted before the planned measurements were reported in [10] and in [3]. Only glasses pha01 and pha03 were measured for viscosity. Exhibit A.8 of the Appendix provides the measured viscosities, the results of the Fulcher fits, and the predictions at $1150^{\circ} \mathrm{C}$ for these two PHA Phase 3 glasses. The information presented in this exhibit (along with predictions from the DWPF viscosity model and the Batch 1 results from [10] and [3]) is summarized in Table 7. 
Table 7: Viscosity Results (in Poise) By Glass ID

\begin{tabular}{|c|c|c|c|c|}
\hline Glass ID & $\begin{array}{l}\text { Viscosity } \\
\text { (Poise) } \\
@ 1150^{\circ} \mathrm{C}\end{array}$ & $\begin{array}{c}\text { Predicted } \\
\text { (measured } \\
\text { composition) }\end{array}$ & $\begin{array}{c}\text { Predicted } \\
\text { (bias-corrected } \\
\text { composition) }\end{array}$ & $\begin{array}{c}\text { Predicted } \\
\text { (target } \\
\text { composition) }\end{array}$ \\
\hline Batch 1 & $\begin{array}{c}48.6,49.7,46,4 \\
48.9,47.3\end{array}$ & $\begin{array}{c}\quad 44.2 \\
(\text { Sharp-Schurtz) }\end{array}$ & & 56.2 \\
\hline pha01 & 43.9 & 57.7 & 57.7 & 70.2 \\
\hline pha02 & Not measured & 56.0 & 60.8 & 53.1 \\
\hline pha03 & 33.1 & 39.4 & 42.6 & 39.1 \\
\hline pha04 & Not measured & 71.8 & 77.3 & 67.4 \\
\hline pha05 & Not measured & 45.8 & 50.1 & 50.6 \\
\hline pha06 & Not measured & 39.0 & 42.1 & 36.9 \\
\hline
\end{tabular}

The melt viscosities at $1150^{\circ} \mathrm{C}$ for the two PHA glasses (pha01 and pha03) are within the DWPF operating range, although significantly lower than the viscosities of the sludge-only glasses that have been run in the DWPF for the last several years. Based upon the measurements for these two glasses and the predictions for the others, processing these glasses in the DWPF would evidently not be a problem from a viscosity perspective.

Whether one uses the targeted, measured, or bias-corrected measured compositions to predict viscosities using the current model, the model viscosities are higher than the measured viscosities for the two glasses tested. A trend observed in these data is a decrease in measured viscosity as the PHA concentration is increased in the glass from 7 to $13 \mathrm{wt} \%$.

\section{Liquidus Temperature $\left(\mathbf{T}_{\mathbf{L}}\right)$}

The standard ASTM procedure for measuring liquidus temperature uses a gradient furnace. The equipment for determining liquidus temperature by this method is being installed and tested within SRTC in a clean laboratory. Due to the presence of depleted uranium in the glass samples (as well as the early stage of equipment setup), we were not able to use this method for liquidus determination. A decision was, therefore, made to perform isothermal melts using reasonable quantities of the glass to bound the liquidus temperature.

XRD was selected as the method of detection for crystal formation in these glasses. It is estimated that the sensitivity of XRD (non-quantitative) is $\sim 0.7$ to $1 \mathrm{wt} \%$ for a crystalline phase (in this case, Trevorite [11]). Therefore, for this type of measurement, absence of detection of a crystalline phase was evidence that the liquidus temperature is less than the temperature of that isothermal hold. On the other hand, detection of Trevorite (or any other primary crystalline phase) indicates that the liquidus temperature is higher than the temperature of the isothermal hold.

Each glass underwent an isothermal hold at $900^{\circ} \mathrm{C}$. Approximately 5 grams of glass were placed in a small platinum crucible and transferred to a furnace already heated to $1150^{\circ} \mathrm{C}$. After a four-hour hold period, the temperature was reduced to $900^{\circ} \mathrm{C}$ and held at that temperature for 24 hours. The crucible was then removed from the furnace, and the glass allowed to cool within the crucible at room temperature. For these experiments, twelve glasses were treated together. The twelve glasses consisted of the six CST and six PHA glasses containing $22 \mathrm{wt} \%$ Purex simulated sludge. Therefore, the CST and PHA glasses experienced essentially identical heat treatments. The six PHA glasses at $900^{\circ} \mathrm{C}$ were submitted for XRD analysis. Care was taken to obtain glass that was not part of the top glass surface. The glass pieces, although mainly from the bulk, usually included part of the bottom surface (i.e., that surface in contact with the crucible).

The XRD analysis revealed no crystals in any of the glasses to the detection limit of the technique $(\sim 0.7$ to $1.0 \mathrm{wt} \%)$. Therefore, the bounding estimates of liquidus temperatures for these six PHA glasses were: 


\section{Table 8: Liquidus Temperatures}

\begin{tabular}{|lc|}
\hline GLASS ID & LIOUIDUS TEMPERATURE \\
\hline pha01 & $<900^{\circ} \mathrm{C}$ \\
pha02 & $<900^{\circ} \mathrm{C}$ \\
pha03 & $<900^{\circ} \mathrm{C}$ \\
pha04 & $<900^{\circ} \mathrm{C}$ \\
pha05 & $<900^{\circ} \mathrm{C}$ \\
pha06 & $<900^{\circ} \mathrm{C}$ \\
\hline
\end{tabular}

These bounding liquidus temperatures are well below the nominal PAR value of $1025^{\circ} \mathrm{C}$ [12] and readily meet DWPF processing requirements for liquidus. The model predictions for these six glasses ranged from $949^{\circ} \mathrm{C}$ to $964^{\circ} \mathrm{C}$ using targeted chemical compositions, from $923^{\circ} \mathrm{C}$ to $968^{\circ} \mathrm{C}$ using measured compositions, and $917^{\circ} \mathrm{C}$ to $960^{\circ} \mathrm{C}$ using bias-corrected compositions. These data suggest that the predictions may be conservative for these glasses. A new liquidus model is being developed with a goal of preventing unnecessarily conservative constraints on liquidus.

\section{Surface Crystallization}

For liquidus measurements, crystal formation is considered only in the interior or bulk glass region. Therefore, samples submitted for XRD analysis were bulk samples. However, crystals can form at the interface of the glass and the crucible and/or the glass and air. For completeness, the detection of these surface crystals on the top of the glass is provided in Table 9 as a function of temperature. Only $900^{\circ} \mathrm{C}$ data are provided since XRD revealed no crystals in the six PHA glasses isothermally held at $900^{\circ} \mathrm{C}$ for 24 hours. Consequently, no higher temperature isothermal holds were conducted.

Table 9. Surface Crystals for the Six PHA Glasses at $900^{\circ} \mathrm{C}$ after the 24 hour heat treatment.

\begin{tabular}{|c|c|c|c|c|c|c|}
\hline & pha01 & pha02 & pha03 & pha04 & pha05 & pha06 \\
\hline $1150^{\circ} \mathrm{C}$ & No test & No test & No test & No test & No test & No test \\
\hline $1000^{\circ} \mathrm{C}$ & No test & No test & No test & No test & No test & No test \\
\hline $950^{\circ} \mathrm{C}$ & No test & No test & No test & No test & No test & No test \\
\hline $900^{\circ} \mathrm{C}$ & None & None & None & None & None & None \\
\hline
\end{tabular}

As shown in the table, no surface crystallization was detected for any of the glasses at $900^{\circ} \mathrm{C}$.

\section{Phase Separation}

The formation of separate amorphous phases in glass is referred to as amorphous phase separation or inhomogeneity. Crystal formation, as indicated by liquidus measurements, on the other hand, is also a type of phase separation, but reflects crystalline particles within the glass matrix. Amorphous phase separation is to be avoided since the models currently used to predict durability do not apply for glasses predicted to be phase separated. The limit for the homogeneity constraint in the PCCS is nominally (for the Property Acceptance Region, PAR) a value of 211 [12]. For the measurement acceptance region (MAR), the value will be even higher. In order to pass this constraint, the calculated value must be greater than the MAR value. The homogeneity values calculated using the targeted and measured chemical compositions are all below the PAR value. These values are given in Table 10:

Table 10: Homogeneity Property Predictions

\begin{tabular}{|c|c|c|c|}
\hline & \multicolumn{3}{|c|}{$\begin{array}{c}\text { Homogeneity Property Prediction } \\
\text { based on } \\
\text { (Acceptability Requires a Value > 211) }\end{array}$} \\
\hline & $\begin{array}{c}\text { Target } \\
\text { Composition }\end{array}$ & $\begin{array}{c}\text { Measured } \\
\text { Composition }\end{array}$ & $\begin{array}{c}\text { Bias-Corrected } \\
\text { Composition }\end{array}$ \\
\hline Glass ID & 200.1 & 204.2 & 199.9 \\
\hline pha01 & 199.8 & 199.1 & 196.9 \\
\hline pha02 & 199.4 & 198.6 & 196.6 \\
\hline pha03 & 198.4 & 195.7 & 193.9 \\
\hline pha04 & 198.0 & 193.3 & 191.3 \\
\hline pha05 & 197.7 & 198.7 & 196.6 \\
\hline pha06 & & & \\
\hline
\end{tabular}


The homogeneity constraint was developed for glasses that do contain PHA. Therefore, the predictability of phase separation by this model should be applicable. A significant search for phase separation in these glasses is beyond the scope of work for this task, except when routine SEM analysis is performed. For these six glasses no SEM analyses were performed.

\section{CONCLUSIONS}

The results presented in this report are for six Phase 3 PHA glasses, each of which was targeted to contain 22 wt\% simulated PUREX sludge on an oxide basis. The target PHA concentration was varied from 7 to 10 to $13 \mathrm{wt} \%$ oxides both at 1.25 and $2.5 \mathrm{wt} \%$ (on an oxide basis) washed MST.

All six of these glasses were durable when compared to the EA glass (as determined by the 7-day PCT) and processible (from measured viscosity and bounding liquidus temperature data). Therefore, the results imply that DWPF would be able to run these six glass formulations at 22 wt \% PUREX waste loading on an oxide basis.

The models currently in DWPF's PCCS were used to predict durability, homogeneity, liquidus, and viscosity for these six glasses. All six glasses were predicted to be phase separated, and consequently prediction of glass durability is precluded with the current models. However, the measured durabilities (as determined by the PCT) were within the $95 \%$ confidence bands of the model. Further efforts will be required to resolve this issue on phase separation (inhomogeneity).

The liquidus model predicted acceptable liquidus temperatures for all six glasses. The bounding liquidus temperatures that were measured $\left(<900^{\circ} \mathrm{C}\right)$ were below the model predictions. The measured viscosities were below the predictions of the model and therefore, conservative to the upper limit of viscosity. The lowest measured viscosity value was 33.1 poise at $1150^{\circ} \mathrm{C}$, corresponding to the glass with the highest level of PHA and at the lower level of MST. The model predictions may not be conservative with respect to the lower operating limit. 


\section{REFERENCES}

[1] Elder, H. H., "Technical Task Request: DWPF Waste Qualification - DWPF Coupled Operation Chemistry," HLW-SDT-TTR-99-07.0, February 2, 1999.

[2] Harbour, J. R. and T. B. Edwards, "Technical Task and QA Plan: DWPF Coupled Operation Chemistry - PHA Glass Testing," WSRC-RP-99-00218, Revision 1, April 23, 1999.

[3] Edwards, T. B., J. R. Harbour, and R. J. Workman, "Composition and Property Measurements for PHA Phase 1 Glasses (U)," WSRC-TR-99-00262, Revision 0, August 4, 1999.

[4] ASTM C1285-97, "Standard Test Methods for Determining Chemical Durability of Nuclear Waste Glasses: The Product Consistency Test (PCT)," 1997.

[5] Edwards, T. B., J. R. Harbour, and R. J. Workman, "Composition and Property Measurements for CST Phase 3 Glasses (U)," WSRC-TR-99-00291, Revision 0, August 18, 1999.

[6] Harbour, J. R. and T. B. Edwards, "Analytical Study Plan-PHA: DWPF Coupled Operation Chemistry - PHA Glass Testing," WSRC-RP-99-00315, Revision 0, April 14, 1999.

[7] Edwards, T. B., J. R. Harbour, and R. J. Workman, "Composition and Property Measurements for CST Phase 2 Glasses (U)," WSRC-TR-99-xxxx, Revision 0, DRAFT, August 17, 1999.

[8] Jantzen, C. M., J. B. Pickett, K. G. Brown, T. B. Edwards, and D. C. Beam, "Process/Product Models for the Defense Waste Processing Facility (DWPF): Part I. Predicting Glass Durability from Composition Using a Thermodynamic Hydration Energy Reaction Model (THERMO) (U)," WSRC-TR-93-672, Rev. 1, September 28, 1995.

[9] Schumacher, R. F. and D. K. Peeler, "Establishment of Harrop, High-Temperature Viscometer," WSRC-RP-98-00737, Revision 0, September 1998.

[10] Schumacher, R. F., R. J. Workman, J. R. Harbour, and T. B. Edwards, "Measurements of DWPF Glass Viscosity - Interim Report," WSRC-RP-99-00350, Revision 0, May 5, 1999.

[11] Cicero, C. A., S. L. Marra, and M. K. Andrews, "Phase Stability Determinations of DWPF Waste Glasses (U)," WSRC-TR-93-227, Revision 0, 1993.

[12] Brown, K. G. and R. L. Postles, "SME Acceptability Determination for DWPF Process Control (U)," WSRC-TR-95-0364, Revision 3, February 21, 1996. 
WSRC-TR-99-00292

Revision 0

This page intentionally left blank.

WSRC Confidential and P'roprietary Information. 
WSRC-TR-99-00292

Revision 0

\section{Appendix:}

\section{Supplemental Tables and Exhibits}


Table A.1: Composition Measurements Using Peroxide Fusion Dissolutions (expressed as cation weight fractions)

\begin{tabular}{|c|c|c|c|c|c|c|c|}
\hline Glass ID & Block & Seq & LIMS \# & Lab ID & $\mathbf{B}$ & $\mathrm{Ca}$ & $\mathrm{Si}$ \\
\hline Batch 1 & 1 & 1 & $130832 a$ & NA2O2 - BATCH 1-STDI & 0.02437 & 0.00897 & 0.24418 \\
\hline pha06 & $I$ & 2 & $130821 a$ & $\mathrm{Na202}$ A08pf2 & 0.02802 & 0.00672 & 0.22878 \\
\hline pha04 & 1 & 6 & $130823 a$ & $\mathrm{Na202}$ A12pf2 & 0.02672 & 0.00687 & 0.26446 \\
\hline pha04 & 1 & 7 & $130812 \mathrm{a}$ & $\mathrm{Na202}$ A12pfl & 0.02628 & 0.00690 & 0.25590 \\
\hline Ustd & 1 & 8 & $130835 a$ & $\mathrm{NA2O} 2$ - U STD-1 & 0.02699 & 0.00990 & 0.20714 \\
\hline pha03 & 1 & 10 & $130809 \mathrm{a}$ & $\mathrm{Na} 202$ A02pfl & 0.02779 & 0.00668 & 0.22578 \\
\hline pha02 & 1 & 13 & $130829 a$ & $\mathrm{Na202}$ A05pf2 & 0.02601 & 0.00742 & 0.24439 \\
\hline pha03 & 1 & 14 & $130811 \mathrm{a}$ & $\mathrm{Na} 202 \mathrm{A02pf2}$ & 0.02828 & 0.00625 & 0.22926 \\
\hline Batch 1 & 1 & 15 & $130833 a$ & NA2O2 - BATCH 1-STD2 & 0.02367 & 0.00883 & 0.23907 \\
\hline pha01 & 1 & 16 & $130808 \mathrm{a}$ & $\mathrm{Na202} \mathrm{AO} 1 \mathrm{pfl}$ & 0.02817 & 0.00747 & 0.24866 \\
\hline pha05 & 1 & 17 & $130813 a$ & $\mathrm{Na202}$ AlOpfl & 0.02569 & 0.00671 & 0.23427 \\
\hline Ustd & I & 22 & $130836 a$ & NA2O2 - U Std-2 & 0.02778 & 0.00946 & 0.21495 \\
\hline pha05 & 1 & 23 & $130826 \mathrm{a}$ & $\mathrm{Na} 202$ A10pi2 & 0.02257 & 0.00590 & 0.20867 \\
\hline pha01 & 1 & 24 & $130815 \mathrm{a}$ & $\mathrm{Na202}$ A01pf2 & 0.02739 & 0.00716 & 0.24145 \\
\hline pha02 & 1 & 25 & $130818 \mathrm{a}$ & $\mathrm{Na202}$ A05pf1 & 0.02474 & 0.00682 & 0.23498 \\
\hline pha06 & I & $2 \overline{6}$ & $130814 a$ & $\mathrm{Na202}$ A08pfl & 0.02790 & 0.00715 & 0.23250 \\
\hline Batch 1 & $i$ & 29 & $130834 a$ & NA2O2 - BATCH 1-STD3 & 0.02302 & 0.00860 & 0.23790 \\
\hline Batch 1 & 2 & 1 & $130832 b$ & NA2O2 - BATCH 1-STD1 & 0.02385 & 0.00888 & 0.23525 \\
\hline pha06 & 2 & 2 & $130814 \mathrm{~b}$ & $\mathrm{Na} 202 \mathrm{A08pfl}$ & 0.02911 & 0.00748 & 0.23418 \\
\hline pha01 & 2 & 3 & $130815 \mathrm{~b}$ & $\mathrm{Na202}$ A01pf2 & 0.02965 & 0.00762 & 0.25596 \\
\hline pha05 & 2 & 4 & $130813 b$ & $\mathrm{Na202}$ A10pfl & 0.02622 & 0.00688 & 0.23358 \\
\hline pha02 & 2 & 6 & $130829 b$ & $\mathrm{Na} 202$ A05pf2 & 0.02710 & 0.00775 & 0.24687 \\
\hline Ustd & 2 & 8 & $130835 \mathrm{~b}$ & $\mathrm{NA2O2}$ - U STD-1 & 0.02844 & 0.01014 & 0.21174 \\
\hline pha03 & 2 & 13 & $130809 \mathrm{~b}$ & $\mathrm{Na} 202 \mathrm{A02pfI}$ & 0.02937 & 0.00714 & 0.23375 \\
\hline Batch I & 2 & 15 & $130833 b$ & NA2O2 - BATCH 1-STD2 & 0.02480 & 0.00936 & 0.24325 \\
\hline pha02 & 2 & 16 & $130818 b$ & Na202 A05pf1 & 0.02803 & 0.00756 & 0.25469 \\
\hline pha01 & 2 & 19 & $130808 \mathrm{~b}$ & Na202 A01pf1 & 0.02872 & 0.00778 & 0.24737 \\
\hline pha06 & 2 & 21 & $130821 \mathrm{~b}$ & $\mathrm{Na202}$ A08pf2 & 0.02921 & 0.00704 & 0.23489 \\
\hline Ustd & 2 & 22 & $130836 \mathrm{~b}$ & NA2O2 - U Std-2 & 0.02971 & 0.01010 & 0.22188 \\
\hline pha03 & 2 & 23 & $130811 b$ & $\mathrm{Na} 202$ A02pf2 & 0.03093 & 0.00685 & 0.24507 \\
\hline pha04 & 2 & 24 & $130812 \mathrm{~b}$ & $\mathrm{Na} 202 \mathrm{A12pfl}$ & 0.02864 & 0.00757 & 0.27264 \\
\hline pha05 & 2 & 25 & $130826 \mathrm{~b}$ & $\mathrm{Na202} \mathrm{Al0pr2}$ & 0.02458 & 0.00652 & 0.21907 \\
\hline pha04 & 2 & 27 & $130823 b$ & $\mathrm{Na202}$ A12pi2 & 0.02894 & 0.00761 & 0.27943 \\
\hline Batch 1 & 2 & 29 & $130834 b$ & NA2O2 - BATCH 1-STD3 & 0.02558 & 0.00934 & 0.25263 \\
\hline
\end{tabular}

Notes:

1. Measurements at their detection limits were given values equal to the detection limits.

2. The CST Phase 3 measurements are not shown in this table even though there were completed as part of the same analytical plan. See [5] for a complete listing of the data. 
Table A.2: Composition Measurements From Microwave Preparation (expressed as cation weight fractions)

\begin{tabular}{|c|c|c|c|c|c|c|c|c|c|c|c|c|c|c|c|c|c|c|c|c|}
\hline Glass & & & & & & & & & & & & ICP-ES & & & & & & & & 4 \\
\hline D & Block & Seg & LIMS \# & Lab $\mathbf{D}$ & $\mathrm{Al}$ & $\mathrm{Ca}$ & $\mathrm{Cr}$ & $\mathrm{Cu}$ & $\mathrm{Fe}$ & $\mathbf{L i}$ & $\mathrm{Mg}$ & $\mathrm{Mn}$ & $\mathrm{Na}$ & $\mathrm{Nb}$ & $\mathrm{Ni}$ & $\overline{\mathrm{Si}}$ & $\mathrm{Ti}$ & $\overline{\mathrm{U}}$ & $\overline{\mathbf{Z}}$ & $\mathrm{K}$ \\
\hline Batch 1 & 1 & 1 & $130751 \mathrm{a}$ & W BATCH 1 STD-1 & 0.02614 & 0.00876 & 0.00077 & 0.00319 & 0.09412 & 0.02098 & 0.00860 & 0.01337 & 0.06867 & 0.00048 & 0.0062 & 0.21866 & .00424 & .00300 & .00230 & 02667 \\
\hline pha05 & 1 & 2 & $130745 \mathrm{a}$ & MW A10MW2 & 0.01343 & 0.00668 & 0.00103 & 0.00577 & 0.07063 & 0.02138 & 0.00838 & 0.01264 & 0.06042 & 0.00053 & 0.00681 & 0.22618 & 0.01392 & 0.02513 & 0.00143 & 0.03601 \\
\hline pha01 & 1 & 3 & $130733 \mathrm{a}$ & W A01MW1 & 0.01519 & 0.00716 & 0.00122 & 0.00463 & 0.07063 & 0.02211 & 0.00882 & 0.01597 & 0.06626 & 0.00052 & 0.00756 & 0.23698 & 0.00701 & 0.01306 & 0.00120 & 0.02445 \\
\hline pha06 & 1 & 4 & $130728 \mathrm{a}$ & MW A08MW I & 0.01391 & 0.00673 & 0.00106 & 0.00755 & 0.07097 & 0.02018 & 0.00798 & 0.01387 & 0.06193 & 0.00050 & 0.00697 & 0.22019 & 0.01398 & 0.02232 & 0.00118 & 0.04664 \\
\hline Ustd & 1 & 8 & $130754 \mathrm{a}$ & MW USTD-1 & 0.02184 & 0.00939 & 0.00186 & 0.00017 & 0.09933 & 0.01456 & 0.00726 & 0.02198 & 0.09063 & 0.00052 & 0.00916 & 0.20997 & 0.00626 & 0.02223 & 0.00017 & 0.02437 \\
\hline pha04 & 1 & 12 & $130737 \mathrm{a}$ & MW A12MW1 & 0.01344 & 0.00640 & 0.00092 & 0.00448 & 0.05904 & 0.02305 & 0.00895 & 0.01387 & 0.06371 & 0.00049 & 0.00655 & 0.24880 & 0.01436 & 0.01046 & & \\
\hline pha05 & 1 & 14 & $130742 a$ & MW A10MW1 & 0.01324 & 0.00651 & 0.00102 & 0.00572 & 0.07011 & 0.02109 & 0.00830 & 0.01249 & 0.05947 & .00050 & 0.00671 & 0.22963 & 0.01378 & 0.02482 & 0.00102 & .03490 \\
\hline Batch & I & 15 & $130752 \mathrm{a}$ & MW BATCHI STD-2 & 0.02633 & 0.00878 & 0.00076 & 0.00321 & 0.09623 & 0.02108 & 0.00871 & 0.01352 & 0.06890 & 0.00048 & 0.00633 & & & & & 0.02686 \\
\hline pha03 & 1 & 16 & $130735 \mathrm{a}$ & MW A02MW1 & 0.01365 & 0.00685 & 0.00118 & 0.00817 & 0.07111 & 0.02068 & 0.00820 & 0.01317 & 0.06120 & & 0.00685 & 0.21826 & 0.00708 & 0.02441 & & 0.04590 \\
\hline pha06 & 1 & 18 & $130738 \mathrm{a}$ & MW AOBMW2 & 0.01376 & 0.00691 & 0.00105 & 0.00773 & 0.07047 & 0.02012 & 0.00785 & 0.01372 & 0.06105 & & & 0.22144 & & & & \\
\hline pha01 & 1 & 19 & & $\sqrt{2}$ & 0.04359 & 0.00422 & 0.00090 & 0.00050 & 0.06355 & 0.01925 & 0.00111 & 0.02073 & 0.06785 & 0.00923 & & 0.23877 & 1978 & 120 & 0.00924 & 0.00137 \\
\hline pha02 & 1 & 21 & $130750 \mathrm{a}$ & MW A05MW2 & 0.01452 & 0.00709 & 0.00120 & 0.00471 & 0.06970 & 0.02180 & 0.00841 & 0.01568 & 0.06283 & 0.00051 & 0.00746 & 0.23687 & 0.00695 & & & \\
\hline Ustd & 1 & 22 & & & 0.02178 & 0.00971 & 0.00184 & 0.00015 & 0.09869 & 0.01444 & 0.00718 & 0.02171 & 0.09020 & 0.00050 & 0.00910 & 0.20803 & 0.00621 & .02252 & 0.00016 & 0.02365 \\
\hline pha02 & I & 23 & $130736 \mathrm{a}$ & $\mathbf{M W}$ & 0.01447 & 0.00715 & 0.00111 & 0.00626 & 0.06966 & 0.02154 & 0.00827 & 0.01514 & 0.05989 & & 0.00729 & 0.23490 & 0.00718 & 0.01770 & 0.00114 & \\
\hline pha03 & 1 & 24 & $130740 \mathrm{a}$ & IW2 & 0.01359 & 0.00677 & \begin{tabular}{|l|l|l|l|} 
\\
\end{tabular} & \begin{tabular}{|l|l|}
0.00807 \\
\end{tabular} & 0.07016 & 0.02043 & 0.00814 & 0.01304 & 0.06046 & 0.00051 & 0.00679 & 0.22411 & \begin{tabular}{|l|}
0.00702 \\
\end{tabular} & 0.02417 & 101 & 0.04612 \\
\hline pha04 & 1 & 25 & $130748 \mathrm{a}$ & IW2 & 0.01324 & 0.00642 & 0.00093 & 0.00458 & 0.05881 & 0.02281 & 0.00877 & 0.01376 & 0.06137 & 0.00052 & 0.00657 & 0.24786 & & & & \\
\hline Batch 1 & 1 & 29 & $130753 \mathrm{a}$ & 1 STD-3 & 0.02589 & 0.00898 & \begin{tabular}{|l|l|}
0.00076 \\
\end{tabular} & 0.00324 & 0.09458 & 0.02083 & 0.00854 & 0.01328 & 0.06807 & 0.00051 & 0.00627 & 0.22849 & 0.00424 & 0.00302 & & 0.02607 \\
\hline Batch 1 & 2 & 1 & & MW BA & 0.02605 & 0.00887 & 0.00078 & 0.00321 & 0.09261 & 0.02112 & 0.00869 & 0.01358 & 0.06849 & & & 0.21700 & & & & \\
\hline pha01 & 2 & 2 & $130749 \mathrm{~b}$ & MW & 0.04363 & 0.00419 & 0.00090 & 0.00052 & 0.06275 & 0.01964 & 0.00113 & 0.02126 & 0.06832 & 228 & 350 & 5537 & 972 & 0.00929 & 344 & 0.00156 \\
\hline pha01 & 2 & 6 & $33 \mathrm{~b}$ & IWI & 0.01517 & 0.00721 & 0.00121 & 0.00464 & 0.06884 & 0.02202 & 0.00884 & 0.01602 & 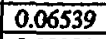 & & & 0.23576 & & 0.01310 & & 0.02492 \\
\hline Ustd & 2 & 8 & $\overline{54 b}$ & MW & 0.02168 & 0.00942 & 0.00187 & 0.00019 & 0.09701 & 0.01446 & \begin{tabular}{|l|l}
0.00730 \\
\end{tabular} & 0.02210 & \begin{tabular}{|l}
0.08931 \\
\end{tabular} & 0.00052 & \begin{tabular}{|l|}
0.00889 \\
\end{tabular} & 0.20584 & 516 & 0.02171 & 20 & 0.02451 \\
\hline pha 04 & 2 & 9 & & W2 & \begin{tabular}{|l|}
0.01336 \\
\end{tabular} & 0.00633 & \begin{tabular}{|l}
0.00099 \\
\end{tabular} & 0.00454 & 0.05812 & 0.02298 & \begin{tabular}{|l|}
0.00893 \\
\end{tabular} & \begin{tabular}{|l|l|}
0.01408 \\
\end{tabular} & \begin{tabular}{|l|}
0.06137 \\
\end{tabular} & & & 0.24654 & & & & 0.02614 \\
\hline pha05 & 2 & 10 & $130742 \mathrm{~b}$ & MW & 0.01320 & 0.00668 & 0.00102 & 0.00581 & 0.06906 & 0.02153 & 0.00837 & 0.01266 & 0.05948 & 550 & 0.0 & 0.22951 & 369 & 0.02417 & & 0.03610 \\
\hline pha06 & 2 & 12 & & aW1 & 387 & 0.00682 & 0.00106 & 0.00761 & 0.06951 & 0.02034 & 0.0 & 0.01397 & 0.06161 & & & & & & & 0.04856 \\
\hline Batch & 2 & 15 & $130752 \mathrm{~b}$ & MW B & 0.02574 & 0.00884 & 0.00076 & 0.00320 & \begin{tabular}{|l}
0.09279 \\
\end{tabular} & 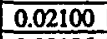 & 0.00866 & 0.01348 & 0.06785 & 0.0 & 0.0 & 0.22752 & & 285 & & 0.02692 \\
\hline pha02 & 2 & 19 & $130750 \mathrm{~b}$ & & & 0.00689 & $\begin{array}{l}0.00119 \\
\end{array}$ & 0.00459 & 0.06800 & 0.02186 & & & 0.00 & & & 23222 & & & & 0.02488 \\
\hline pha03 & 2 & 20 & 130 & & 0.01330 & 0,00671 & 0.00117 & \begin{tabular}{|l|l}
0.00803 \\
\end{tabular} & 0.06951 & 0.02097 & 0.00825 & 0.01328 & 0.06092 & 0.0 & 0.00660 & 0.22449 & 0.00699 & 0.02215 & & 0.04726 \\
\hline pha02 & 2 & 21 & & & & \begin{tabular}{|l|}
0.00701 \\
\end{tabular} & 0.00112 & \begin{tabular}{|l}
0.00616 \\
\end{tabular} & 0.06848 & 0.02174 & & & \begin{tabular}{|l|l}
0.05989 \\
\end{tabular} & & & 0.22876 & & & & 0.03648 \\
\hline Ustd & 2 & 22 & $130755 b$ & MW & 0.02158 & 0.00953 & 0.00185 & 0.00015 & \begin{tabular}{|l|}
0 \\
\end{tabular} & 0.01460 & 0.00726 & 0.02204 & 0.08987 & 0.00 & \begin{tabular}{|l|}
0.00886 \\
\end{tabular} & 0.20522 & 613 & & & 0.02475 \\
\hline pha06 & 2 & 23 & & & & 0.00672 & 0.00102 & \begin{tabular}{|l}
0.00756 \\
\end{tabular} & 0.06936 & 0.02025 & & & \begin{tabular}{|l|}
0.06081 \\
\end{tabular} & & & 0.21993 & & \begin{tabular}{|l|}
0.01904 \\
\end{tabular} & & 0.04873 \\
\hline pha0s & 2 & 24 & $130745 \mathrm{~b}$ & & 0.01321 & 0.00672 & 0.00103 & \begin{tabular}{|l|}
0.00577 \\
\end{tabular} & \begin{tabular}{|l}
0.06927 \\
\end{tabular} & 0.02139 & 0.00839 & 0.01266 & 0.05962 & 0.00053 & \begin{tabular}{|l|}
0.06533 \\
\end{tabular} & 0.22909 & & & & 0.03605 \\
\hline pha03 & 2 & 25 & & & & & 0,00115 & & & 0.02074 & & & 0.06 & & & & & 0.0 & & 0.04682 \\
\hline pha04 & $\sqrt{2}$ & 26 & $130737 \mathrm{~b}$ & MW & 0.01325 & 0.00642 & 0.00091 & 0.00447 & 0.05766 & 0.02287 & 0.00894 & 0.01388 & 0.06284 & 0.00049 & 0.00637 & 0.24462 & 0.01401 & 0.0 & & \\
\hline Batch & $?$ & 29 & $130753 \mathrm{~b}$ & MW BATCH 1 STD & 0.02537 & 0.00868 & 0.00077 & 0.00316 & 0.09215 & 0.02079 & 0.00855 & 0.01334 & 0.06711 & 0.00051 & 0.00608 & 0.22451 & 0.00415 & 0.00302 & 0.00082 & 0.02676 \\
\hline
\end{tabular}

Notes:

1. Measurements at their detection limits were given values equal to the detection limits.

2. The CST Phase 3 measurements are not shown in this table even though there were completed as part of the same analytical plan. See [5] for a complete listing of the data. 

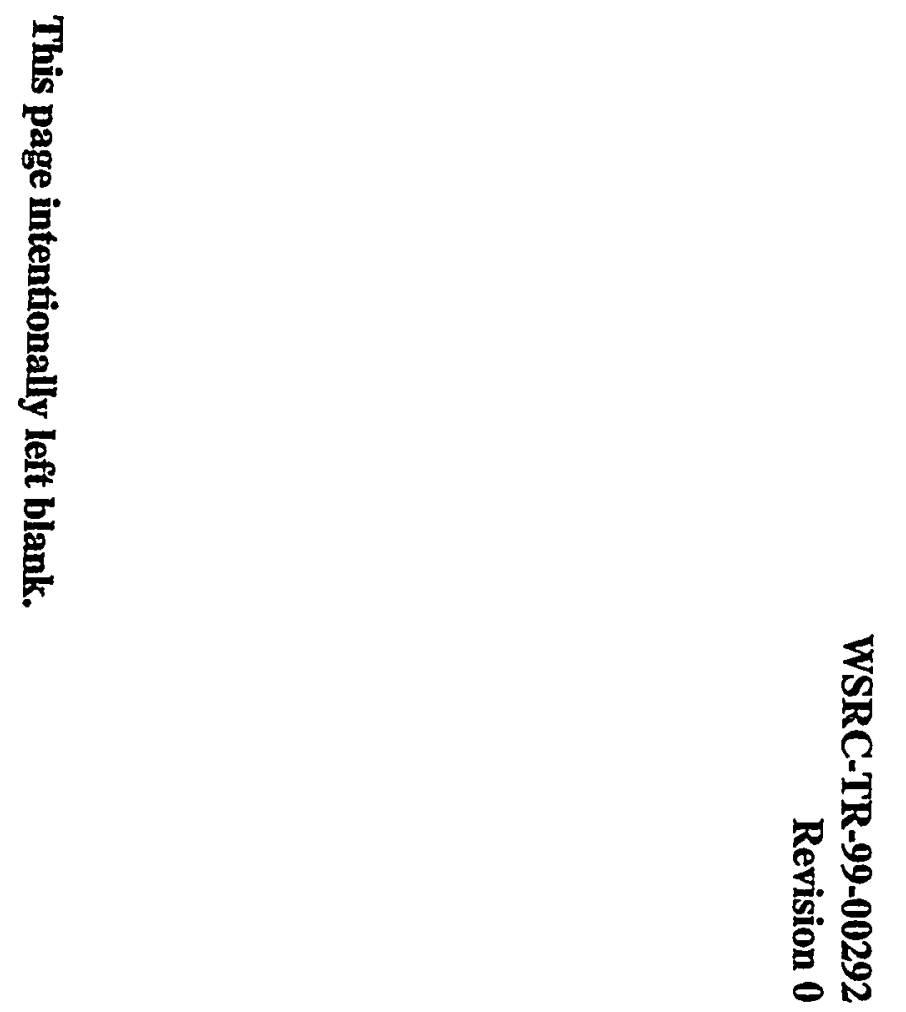


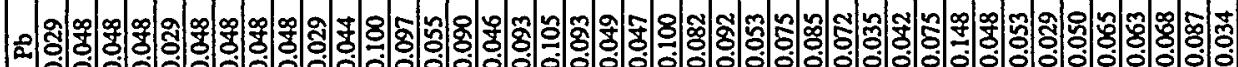

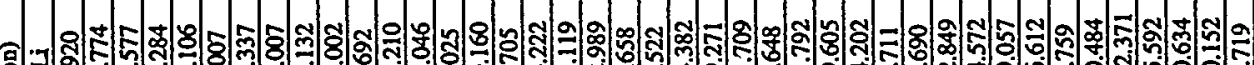
E

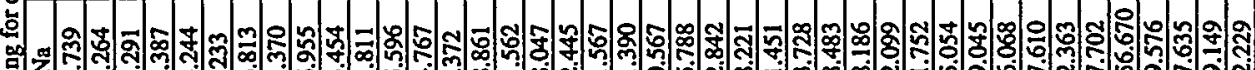

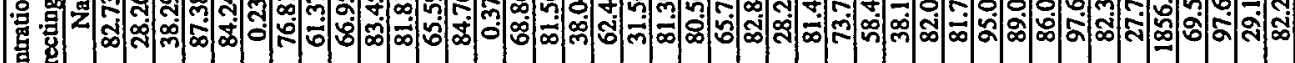

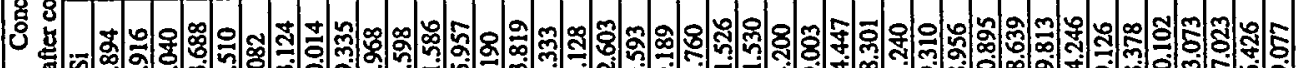

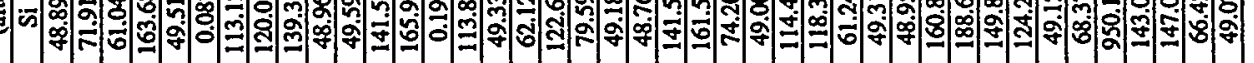

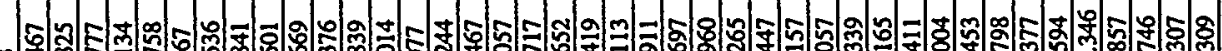

:

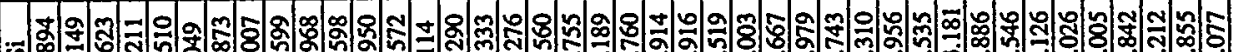

万人

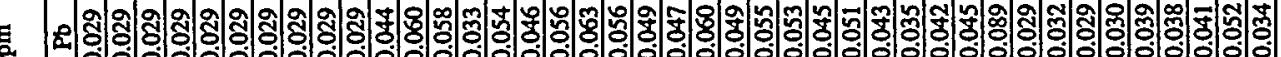

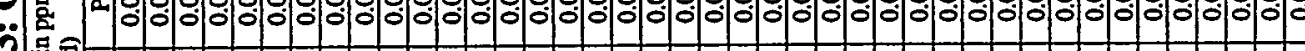

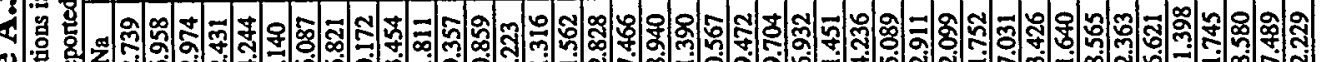

管

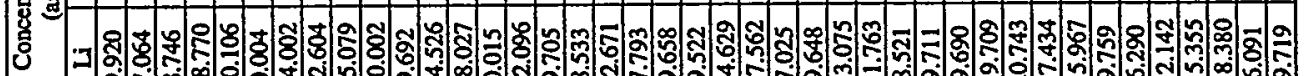
$\Rightarrow$ ât:

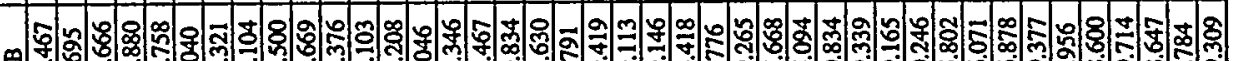

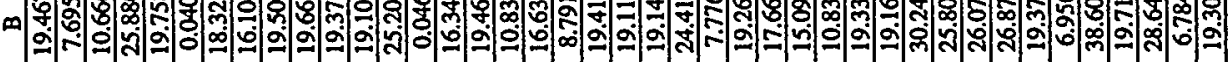

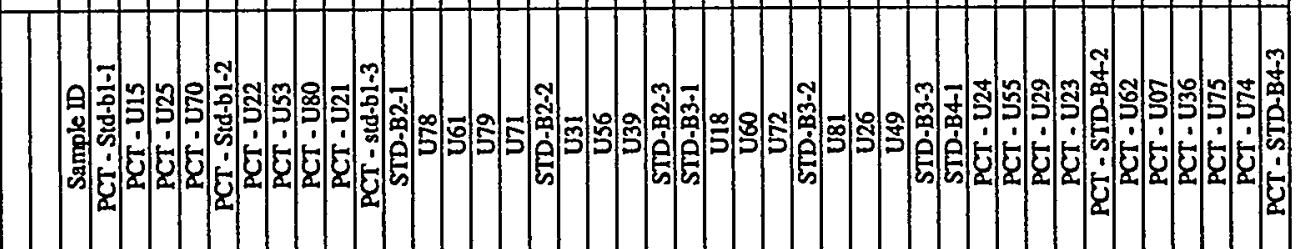

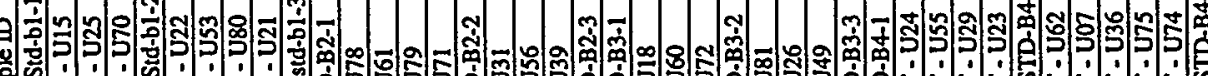

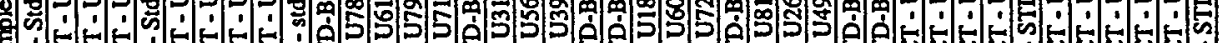

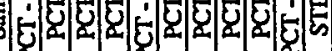

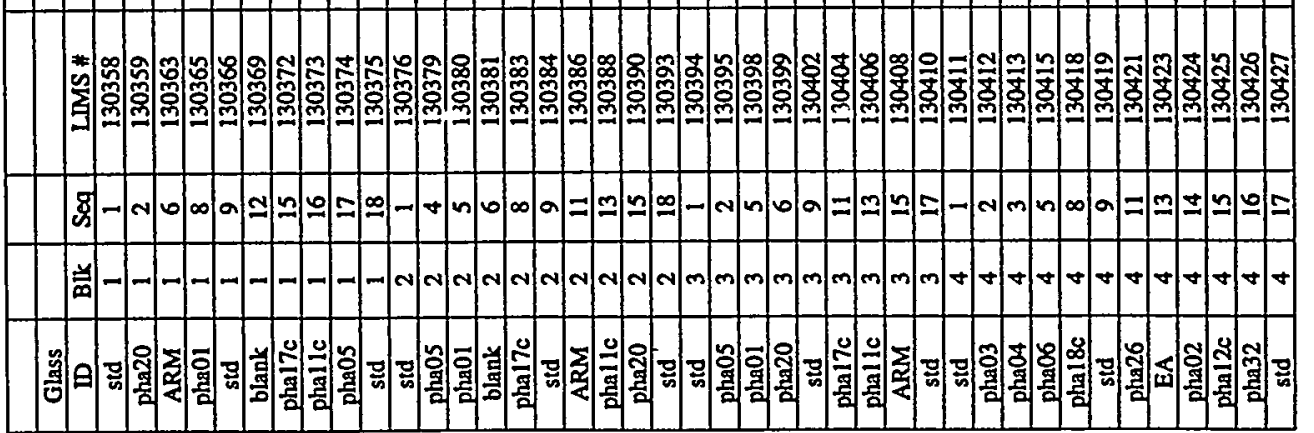

4

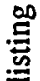

$\frac{\mathrm{e}}{20}$

돔

롱

촌.

ธ్

है

氙

壱

웅용

농.․․

a.

焉

훙

E.

웡을

象

焉

동

逑害

巳

용

은

족 홍

政

灵

क

影

50

过

政

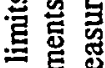

ธ을

㕸

ठ․ㅀ

을

可

范要

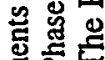

要

害语

层。

$\ddot{\mathrm{s}}$ 
WSRC-TR-99-00292

Revision 0

Table A.3: Composition of PCT Leachate Solutions

\begin{tabular}{|c|c|c|c|c|c|c|c|c|c|c|c|c|c|c|c|c|c|c|}
\hline Glass & & & & & \multicolumn{5}{|c|}{$\begin{array}{l}\text { Concentrations in ppm } \\
\text { (as reported) }\end{array}$} & \multicolumn{5}{|c|}{$\begin{array}{l}\text { Concentrations in ppm } \\
\text { (after correcting for dilution) }\end{array}$} & \multicolumn{3}{|c|}{ Common Logarithm of ppm Concentrations } & atios \\
\hline DD & Blk & Seq & LIMS\# & Sample ID & B & $\mathbf{L i}$ & $\mathrm{Na}$ & $\mathrm{Pb}$ & Si & B & Si & $\mathrm{Na}$ & $\mathbf{L i}$ & $\mathrm{Pb}$ & $\log [\mathrm{B}]$ & $\log [S i]$ & $\log [\mathrm{Na}]$ & $\log [\mathrm{Li}]$ \\
\hline std & 5 & 1 & 130428 & PCT - STD-B5-1 & 19.670 & 10.009 & 83.367 & 0.029 & 49.025 & 19.670 & 49.025 & 83.367 & 10.009 & 0.029 & 1.29380 & 1.69042 & 1.92099 & 1.00039 \\
\hline pha03 & 5 & 2 & 130429 & PCT -U19 & 30.785 & 20.231 & 57.501 & 0.029 & 96.080 & 51.309 & 160.137 & 95.837 & 33.719 & 0.048 & 1.71020 & 2.20449 & 1.98153 & 1.52788 \\
\hline pha26 & 5 & 3 & 130430 & $\mathrm{PCT}-\mathrm{U} 63$ & 7.723 & 6.989 & 17.924 & 0.030 & 43.292 & 12.872 & 72.155 & 29.874 & 11.649 & 0.050 & 1.10964 & 1.85827 & 1.47529 & 1.06627 \\
\hline pha02 & 5 & 4 & 130431 & PCT - U46 & 20.360 & 15.854 & 42.292 & 0.029 & 83.835 & 33.934 & 139.728 & 70.488 & 26.424 & 0.048 & 1.53064 & 2.14528 & 1.84812 & 1.42200 \\
\hline phalsc & 5 & 5 & 130432 & PCT - U14 & 29.831 & 17.563 & 64.045 & 0.029 & 78.043 & 49.719 & 130.074 & 106.744 & 29.272 & 0.048 & 1.69653 & 2.11419 & 2.02834 & 1.46646 \\
\hline pha32 & 5 & 6 & 130433 & PCT - U40 & 6.981 & 6.327 & 18.006 & 0.029 & 40.552 & 11.635 & 67.588 & 30.011 & 10.545 & 0.048 & 1.06578 & 1.82987 & 1.47728 & 1.02306 \\
\hline pha04 & 5 & 8 & 130435 & PCT-U10 & 25.970 & 21.137 & 54.134 & 0.029 & 114.372 & 43.284 & 190.624 & 90.225 & 35.229 & 0.048 & 1.63633 & 2.28018 & 1.95533 & 1.54690 \\
\hline std & 5 & 9 & 130436 & PCT - STD-B5-2 & 19.787 & 10.053 & 83.700 & 0.029 & 48.985 & 19.787 & 48.985 & 83.700 & 10.053 & 0.029 & 1.29638 & 1.69006 & 1.92273 & 1.00230 \\
\hline pha12c & 5 & 12 & 130439 & PCT - U09 & 23.641 & 15.633 & 49.987 & 0.029 & 78.468 & 39.402 & 130.783 & 83.313 & 26.056 & 0.048 & 1.59552 & 2.11655 & 1.92072 & 1.41590 \\
\hline pha06 & 5 & 14 & 130441 & PCT - U69 & 26.835 & 18.083 & 52.672 & 0.029 & 90.100 & 44.726 & 150.170 & 87.788 & 30.139 & 0.048 & 1.65056 & 2.17658 & 1.94344 & 1.47913 \\
\hline EA & 5 & 16 & 130443 & $\overline{P C T}-\mathrm{U} 77$ & 43.471 & 14.619 & 123.358 & 0.029 & 63.060 & 724.531 & 1051.021 & 2056.008 & 243.655 & 0.048 & 2.86006 & 3.02161 & 3.31303 & 2.38678 \\
\hline blank & 5 & 17 & 130444 & PCT - U88 & 0.099 & 0.013 & 0.188 & 0.029 & 0.087 & 0.165 & 0.145 & 0.313 & 0.022 & 0.048 & -0.78251 & .0 .83862 & -0.50398 & -1.66420 \\
\hline std & 5 & 18 & 130445 & PCT - STD-B5-3 & 19.762 & 10.069 & 83.741 & 0.029 & 48.953 & 19.762 & 48.953 & 83.741 & 10.069 & 0.029 & 1.29583 & 1.68978 & 1.92294 & 1.00299 \\
\hline std & 6 & 1 & 130446 & PCT - STD-B6-1 & 19.528 & 9.989 & 82.971 & 0.029 & 48.559 & 19.528 & 48.559 & 82.971 & 9.989 & 0.029 & 1.29066 & 1.68627 & 1.91893 & 0.99952 \\
\hline pha04 & 6 & 3 & 130448 & PCT - U44 & 24.807 & 20.383 & 51.824 & 0.029 & 110.133 & 41.346 & 183.559 & 86.375 & 33.972 & 0.048 & 1.61643 & 2.26378 & 1.93639 & $\frac{0.53113}{1.5313}$ \\
\hline pha32 & 6 & 4 & 130449 & PCT - U30 & 6.980 & 6.354 & 18.030 & 0.029 & 40.017 & 11.634 & 66.696 & 30.051 & 10.590 & 0.048 & 1.06571 & 1.82410 & 1.47785 & 1.02491 \\
\hline EA & 6 & 5 & 130450 & PCT - U58 & 39.043 & 12.446 & 111.786 & 0.029 & 56.482 & 650.730 & 941.386 & 1863.137 & 207.438 & 0.048 & 2.81340 & 2.97377 & 3.27025 & $\frac{2.32471}{2.31689}$ \\
\hline pha06 & 6 & 6 & 130451 & PCT - U68 & 27.686 & 18.652 & 54.244 & 0.029 & 91.908 & 46.144 & 153.183 & 90.408 & 31.087 & 0.048 & 1.66412 & 2.18521 & 1.95621 & 1.49258 \\
\hline pha26 & 6 & 8 & 130453 & PCT - U84 & 7.185 & 6.532 & 16.821 & 0.029 & 41.306 & 11.975 & 68.845 & 28.036 & 10.887 & 0.048 & 1.07828 & 1.83787 & 1.44771 & $\frac{1.03690}{1.03690}$ \\
\hline std & 6 & 9 & 130454 & PCT - STD-B6-2 & 19.632 & 10.025 & 83.330 & 0.029 & 48.630 & 19.632 & 48.630 & 83.330 & 10.025 & 0.029 & 1.29297 & 1.68690 & 1.92080 & 1.00108 \\
\hline pha12c & 6 & 11 & 130456 & PCT - U50 & 5.797 & 4.220 & 12.956 & 0.029 & 20.378 & 9.662 & 33.964 & 21.594 & 7.033 & 0.048 & 0.98506 & 1.53102 & 1.33433 & 0.84717 \\
\hline pha02 & 6 & 13 & 130458 & PCT - U34 & 20.470 & 16.126 & 43.177 & 0.029 & 86.547 & 34.117 & 144.248 & 71.963 & 26.877 & 0.048 & 1.53298 & 2.15911 & 1.85711 & 1.42938 \\
\hline phal 8c & 6 & 14 & 130459 & PCT - U33 & 31.304 & 18.573 & 66.733 & 0.029 & 79.072 & 52.174 & 131.789 & 111.224 & 30.956 & 0.048 & 1.71746 & 2.11988 & 2.04620 & 1.49074 \\
\hline pha03 & 6 & 15 & 130460 & PCT-U01 & 31.086 & 20.415 & 57.814 & 0.029 & 96.338 & 51.811 & 160.567 & 96.359 & 34.026 & 0.048 & 1.71442 & 2.20566 & 1.98389 & 1.53181 \\
\hline blank & 6 & 17 & 130462 & PCT-U87 & 0.061 & 0.006 & 0.332 & 0.029 & 0.052 & 0.102 & 0.087 & 0.553 & 0.010 & 0.048 & -0.99281 & -1.06214 & -0.25700 & $\frac{1.99999}{-1.999}$ \\
\hline std & 6 & 18 & 130463 & PCT - STD-B6-3 & 19.707 & 10.052 & 83.703 & 0.029 & 48.974 & 19.707 & 48.974 & 83.703 & 10.052 & 0.029 & 1.29462 & 1.68997 & 1.92274 & 1.00225 \\
\hline
\end{tabular}

\section{Notes:}

1. Measurements at their detection limits were given values equal to the detection limits.

2. The CST Phase 3 and 4 measurements are not shown in this table even though there were completed as part of the same analytical plan. See [5] for a complete listing of the data. The PHA Phase 4 measurements are shown in this table, but no addition investigation into these data is provided in this report. 
Exhibit A.1: Measurements by Glass Sample ID by Oxide

Al203 By Glass Sample ID

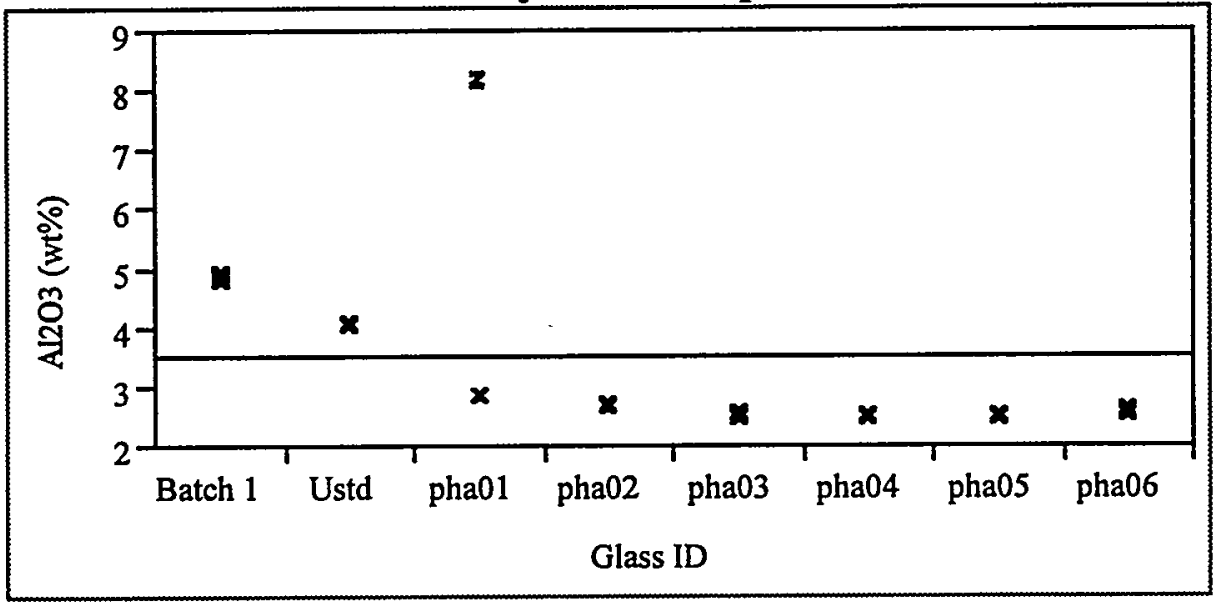

B203 By Glass Sample ID

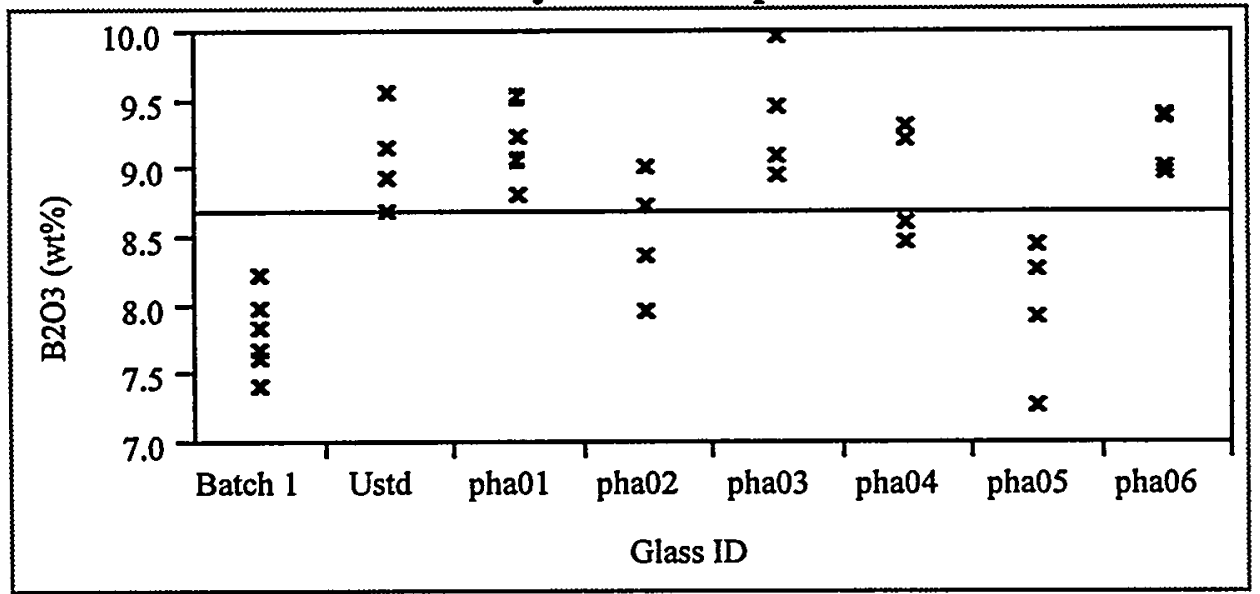

CaO MW By Glass Sample ID

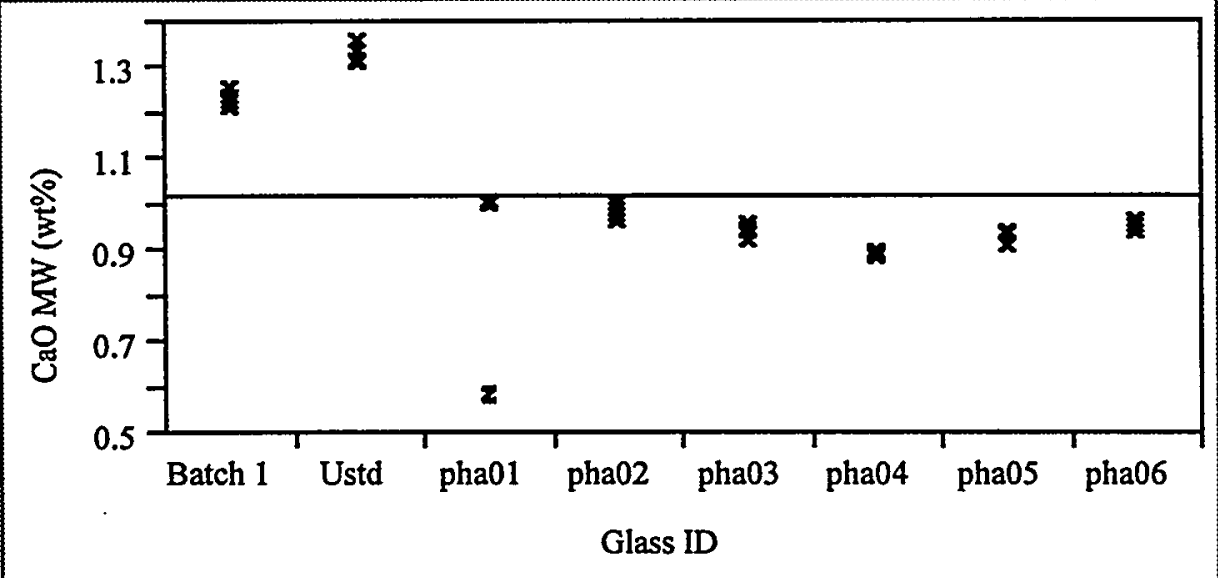


Exhibit A.1: Measurements by Glass Sample ID by Oxide (continued)

\section{CaO pf By Glass Sample ID}

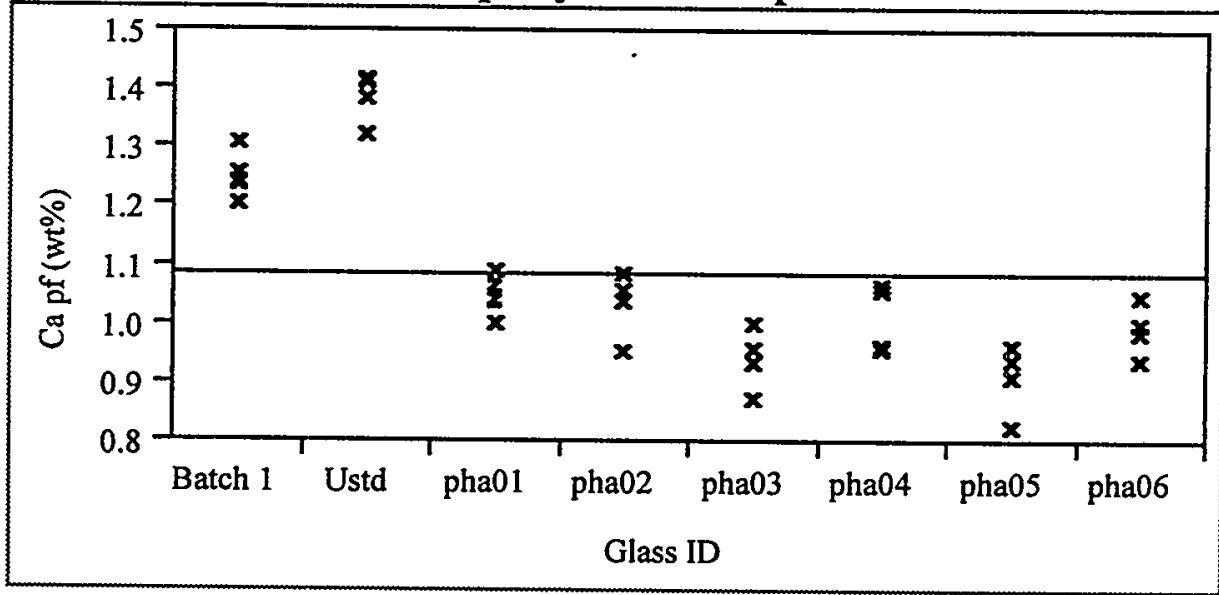

\section{CaO By Glass Sample ID}

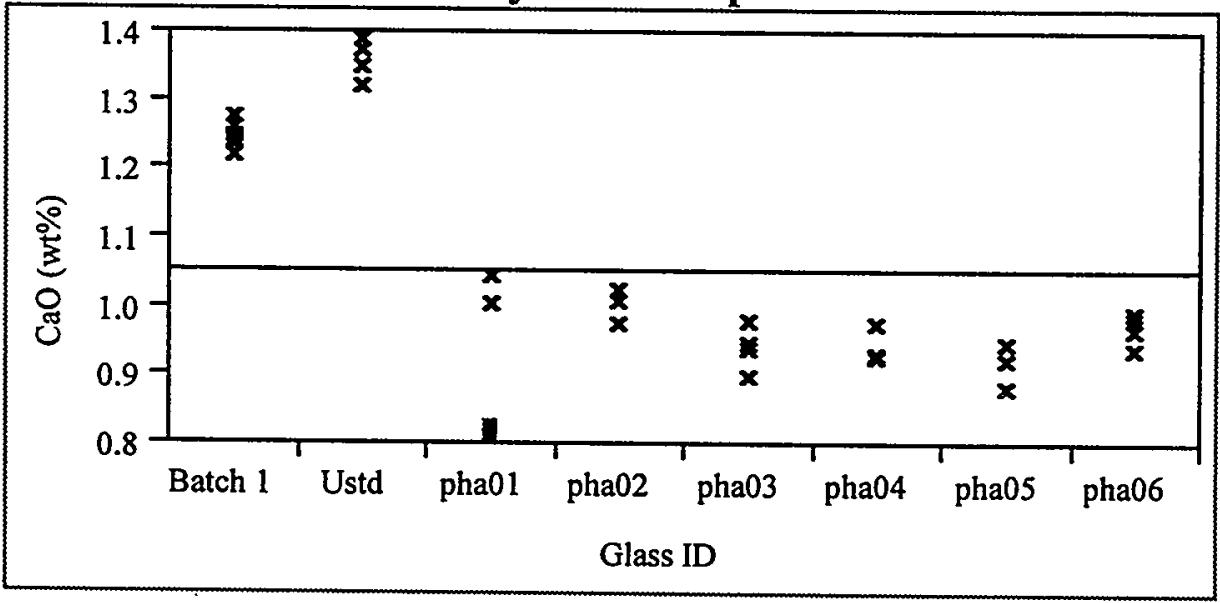

Cr203 By Glass Sample ID

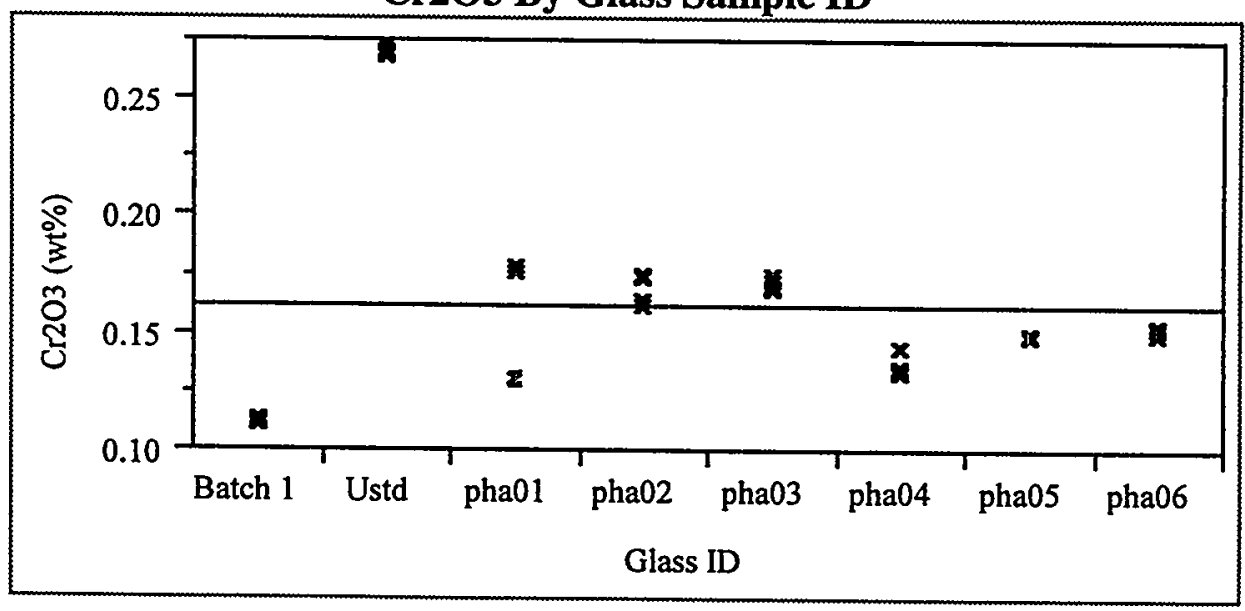


Exhibit A.1: Measurements by Glass Sample ID by Oxide (continued)

\section{CuO By Glass Sample ID}

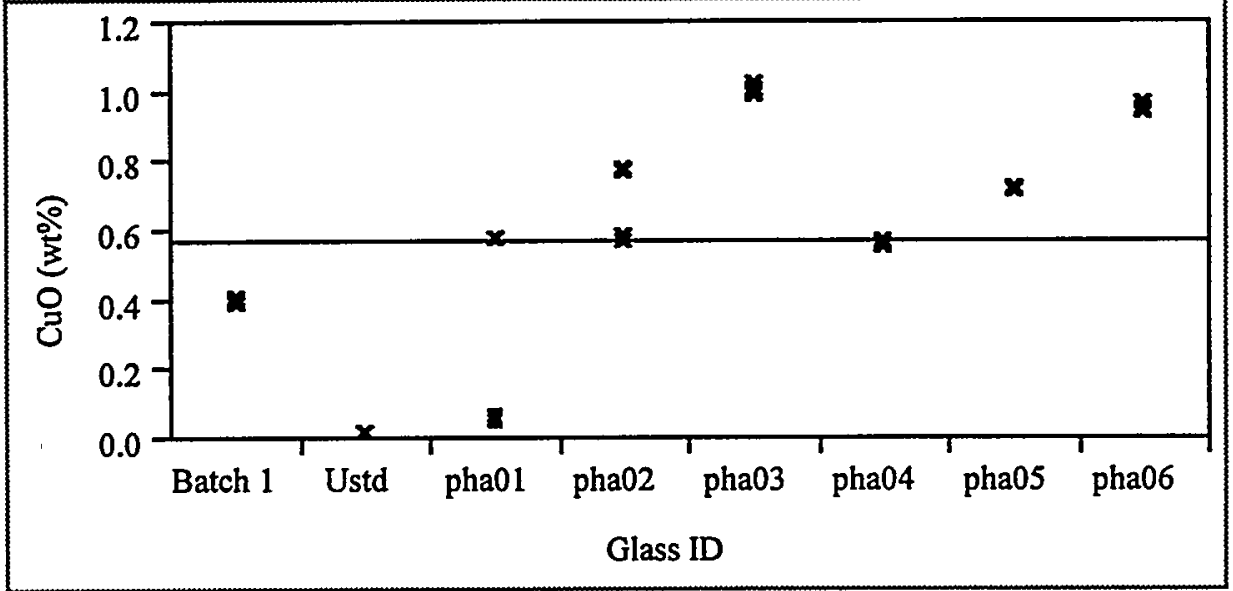

Fe2O3 By Glass Sample ID

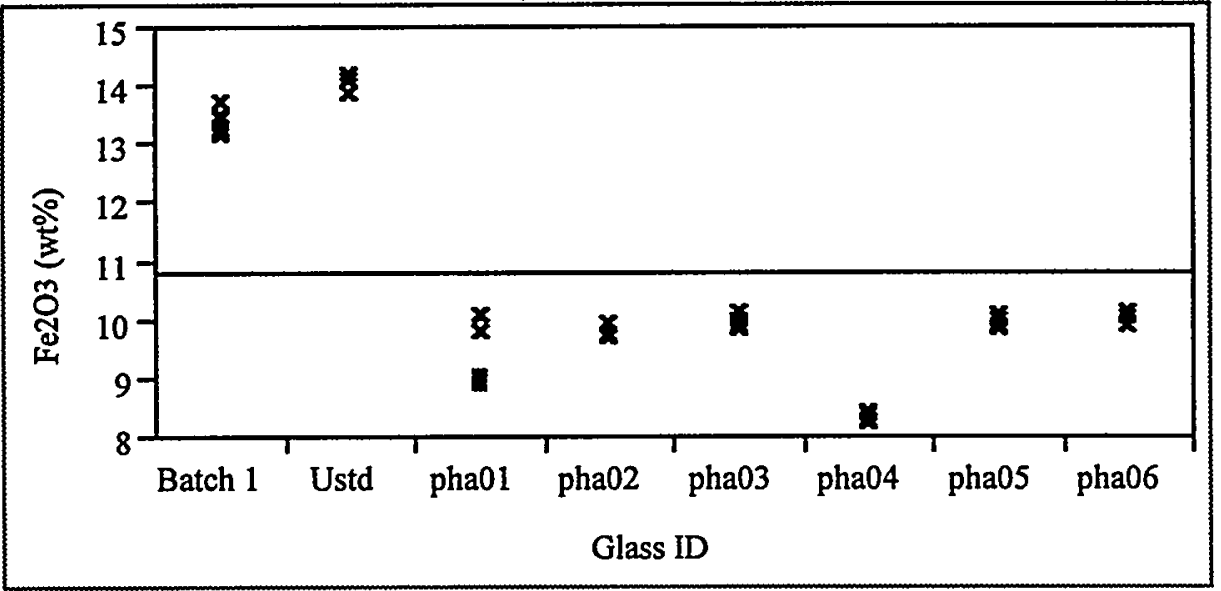

K20 By Glass Sample ID

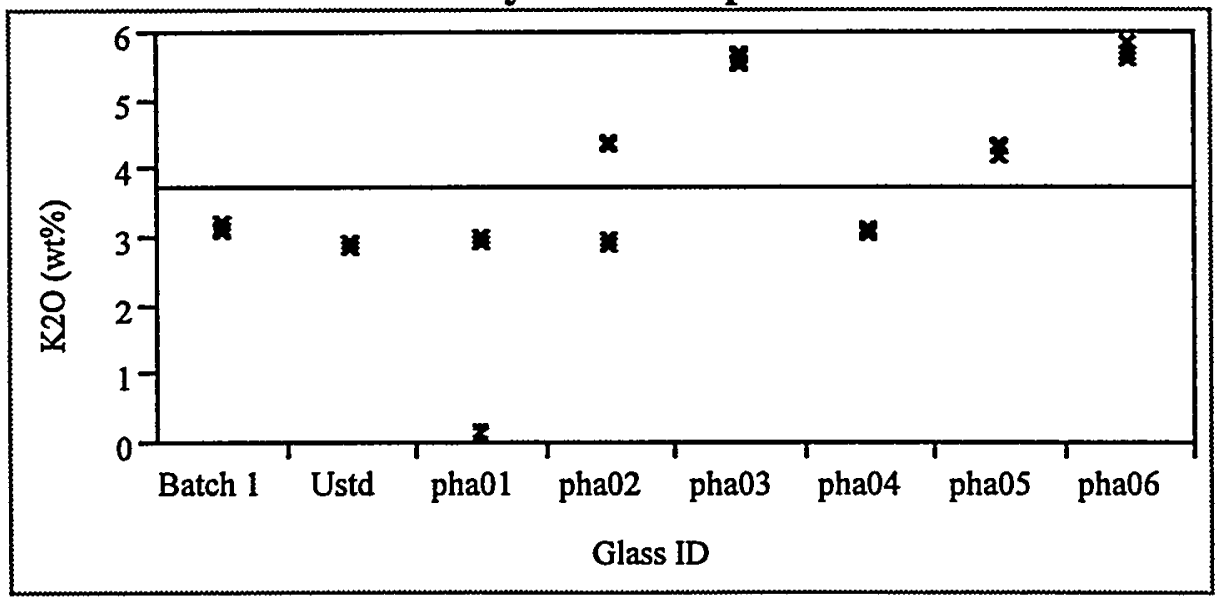

WSRC Confidentiai and Proprietary Information. 
Exhibit A.1: Measurements by Glass Sample ID by Oxide (continued)

\section{Li20 By Glass Sample ID}

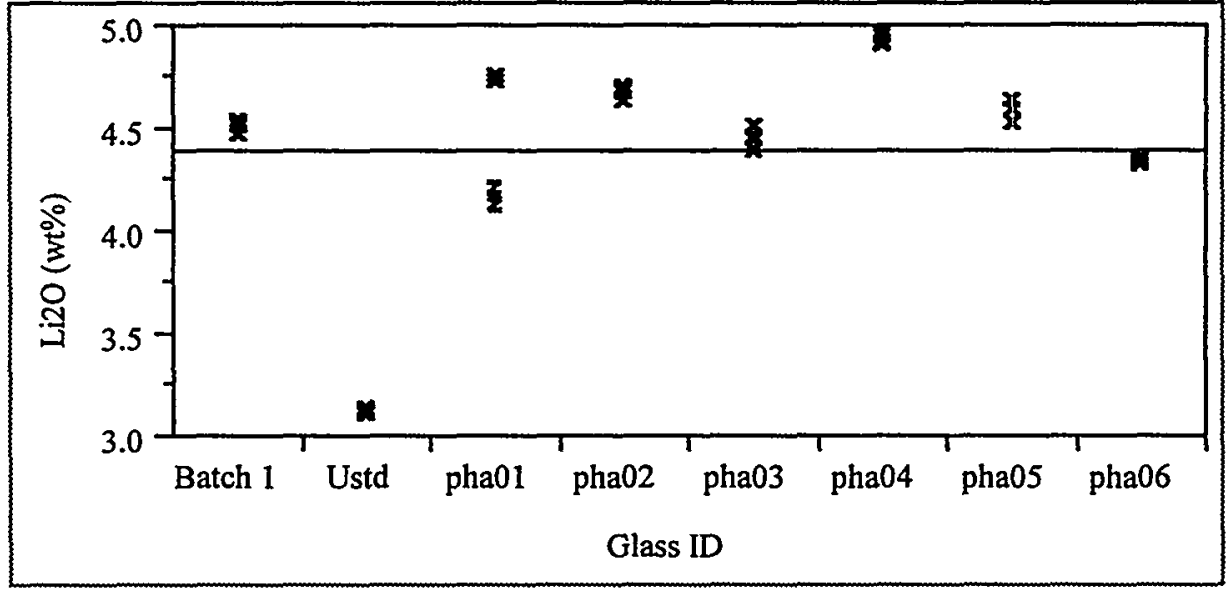

MgO By Glass Sample ID

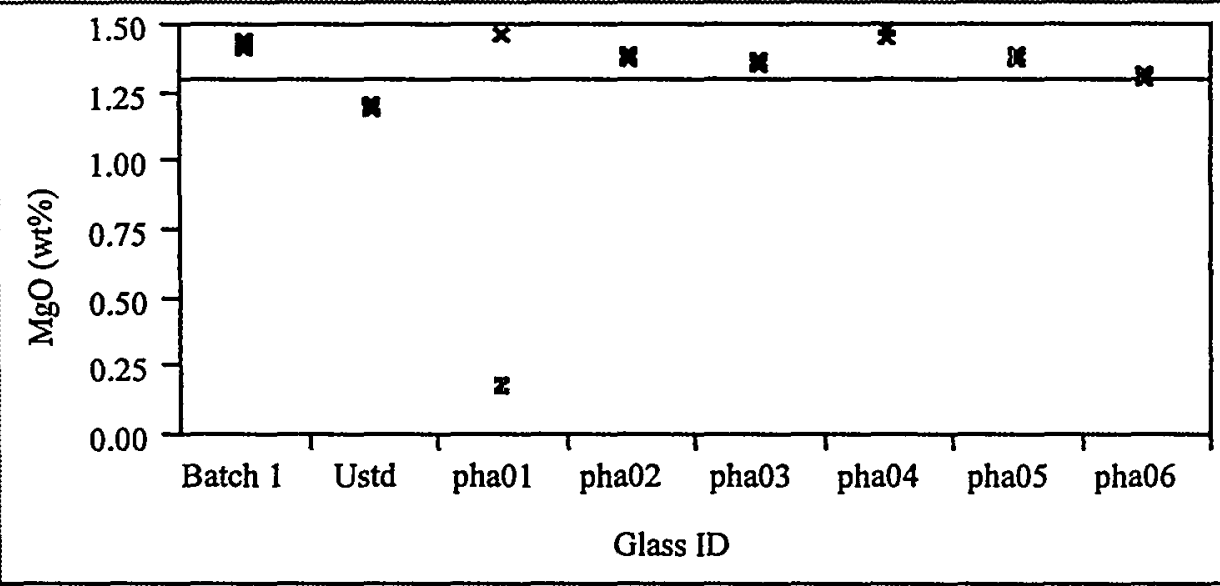

MnO By Glass Sample ID

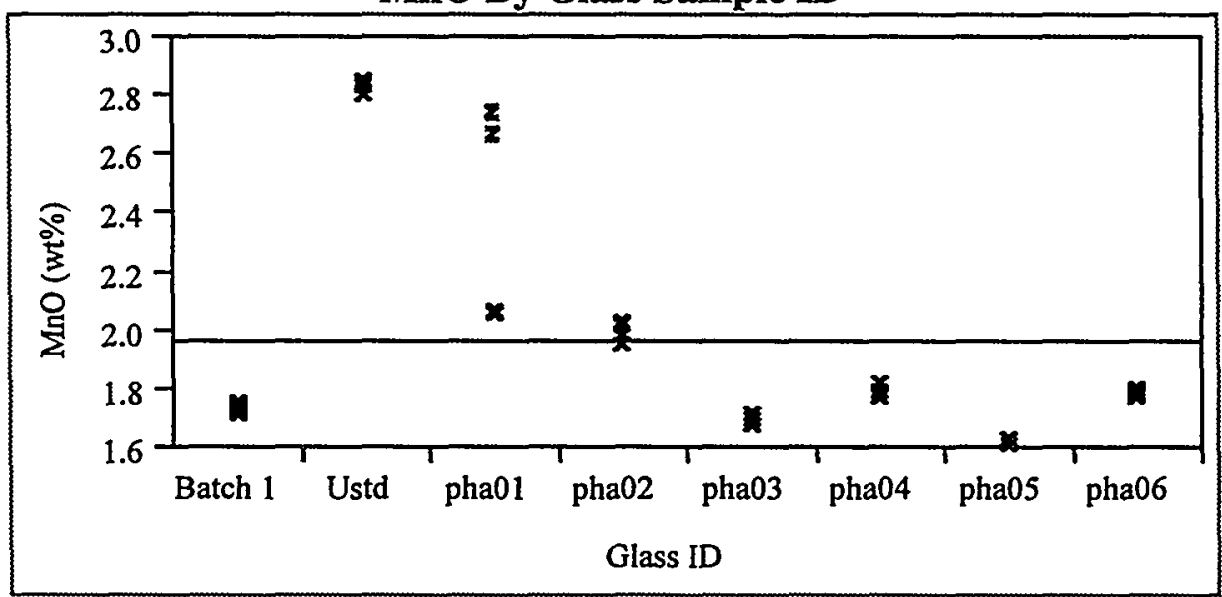


Exhibit A.1: Measurements by Glass Sample ID by Oxide (continued)

Na2O By Glass Sample ID

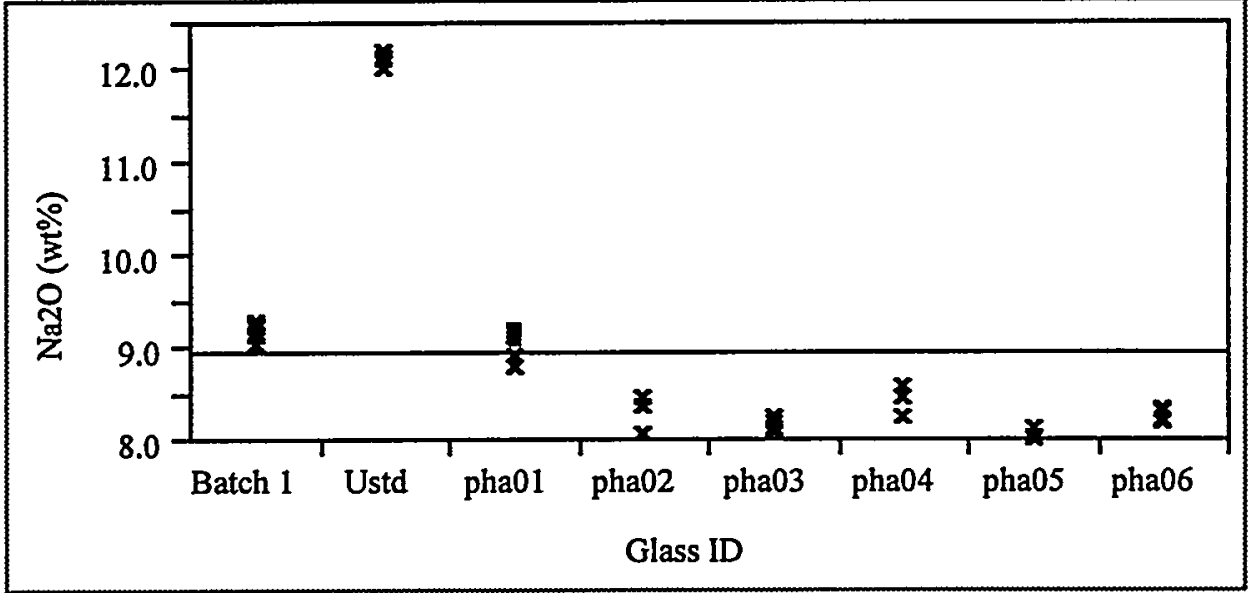

NiO By Glass Sample ID

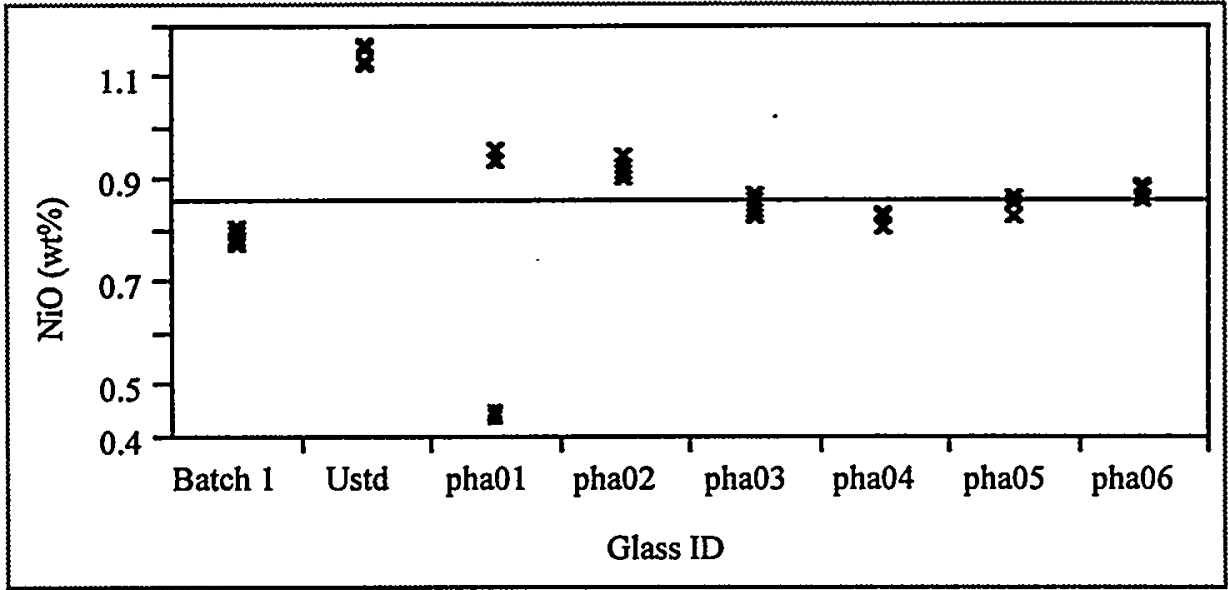

SiO2 MW By Glass Sample ID

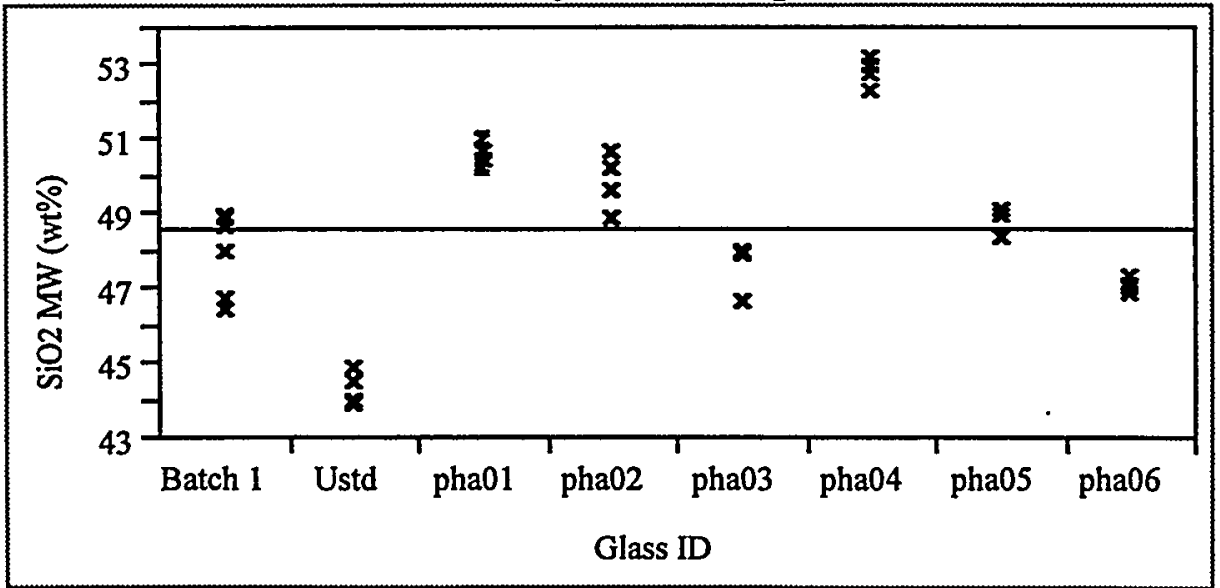


Exhibit A.1: Measurements by Glass Sample ID by Oxide (continued)

SiO2 pf By Glass Sample ID

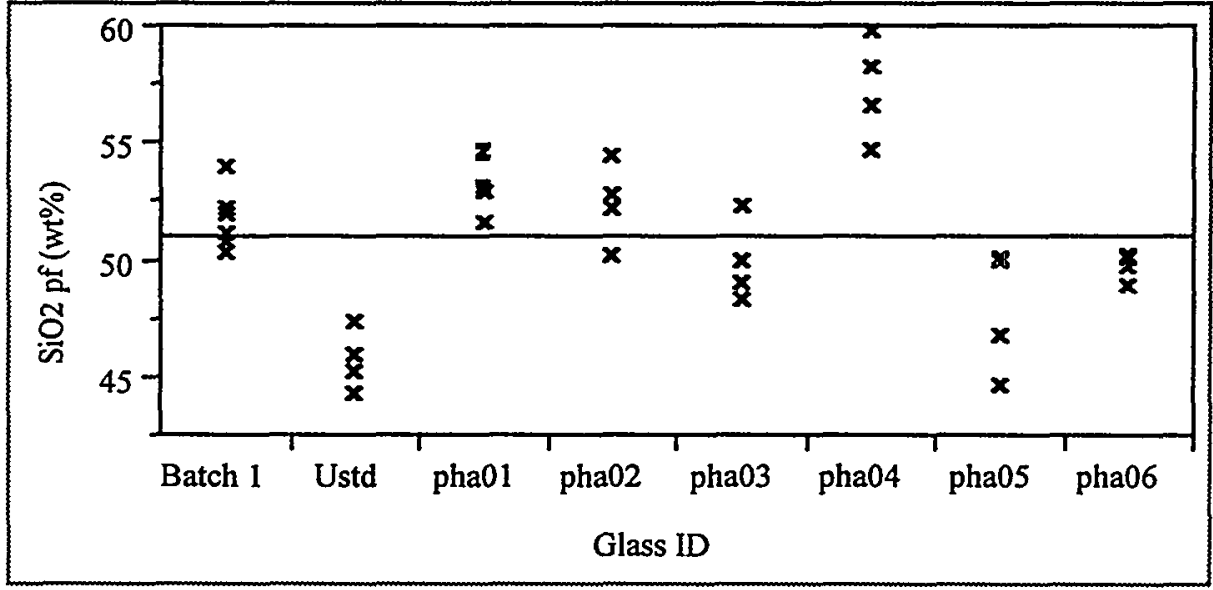

SiO2 By Glass Sample ID

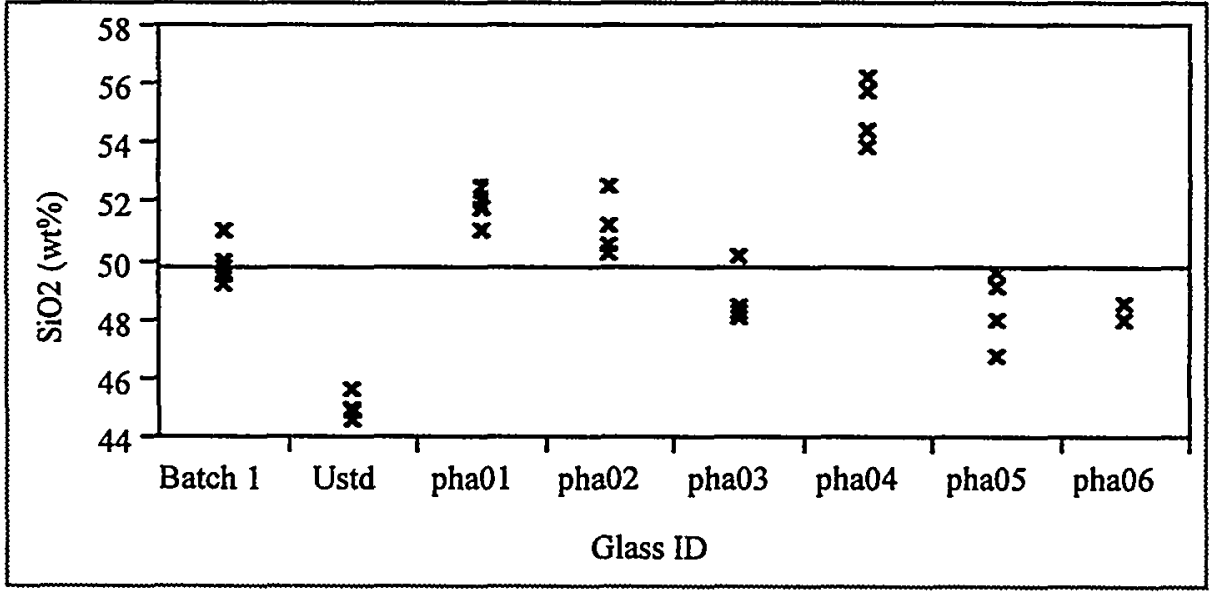

TiO2 By Glass Sample ID

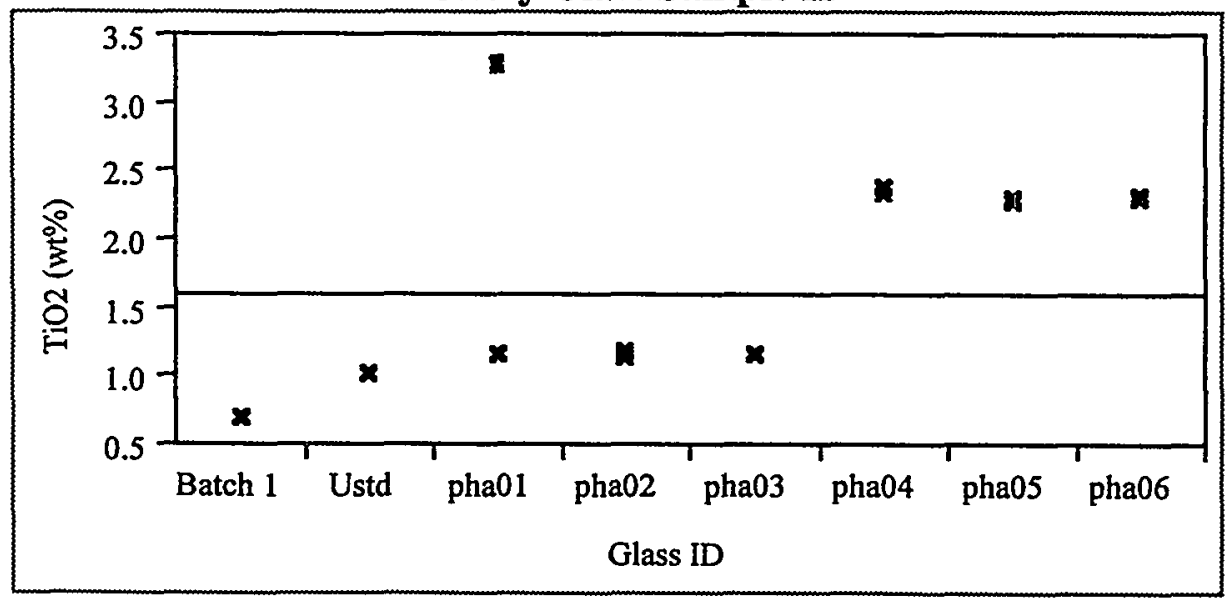


Exhibit A.1: Measurements by Glass Sample $\mathrm{ID}$ by Oxide (continued)

U308 By Glass Sample ID

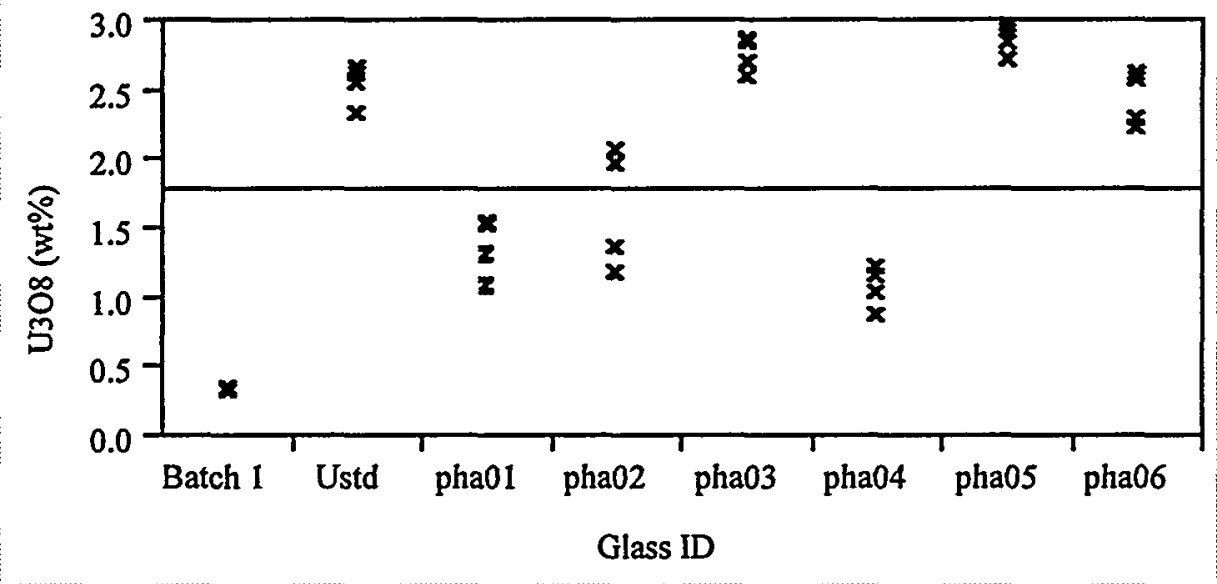

ZrO2 By Glass Sample ID

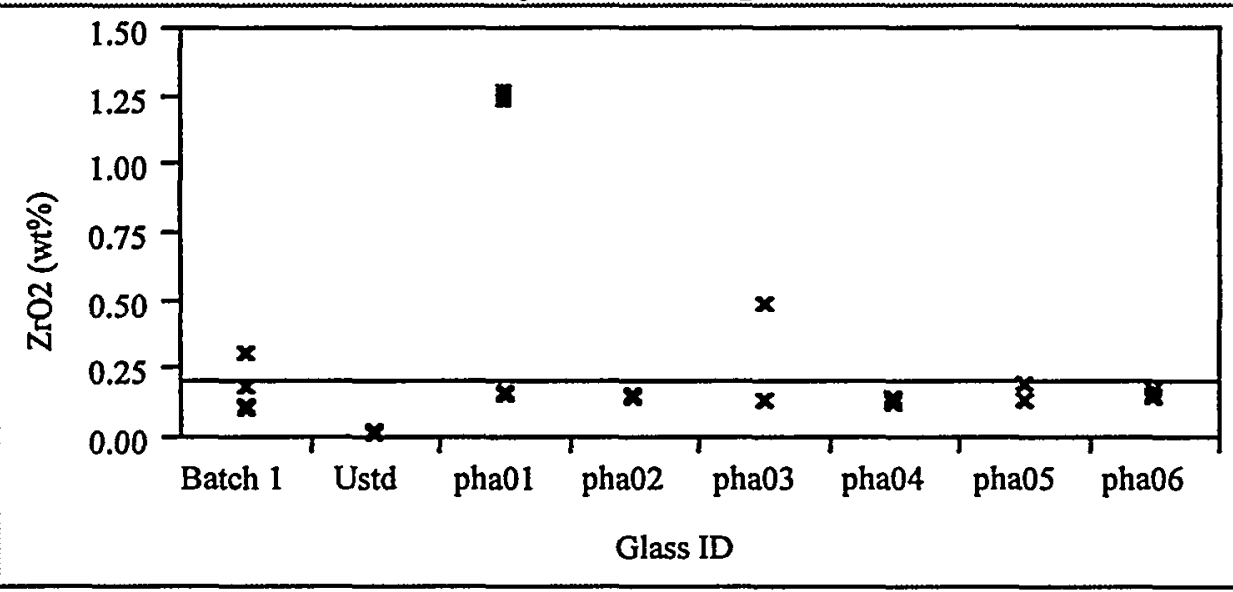

Sum of Oxides By Glass Sample ID

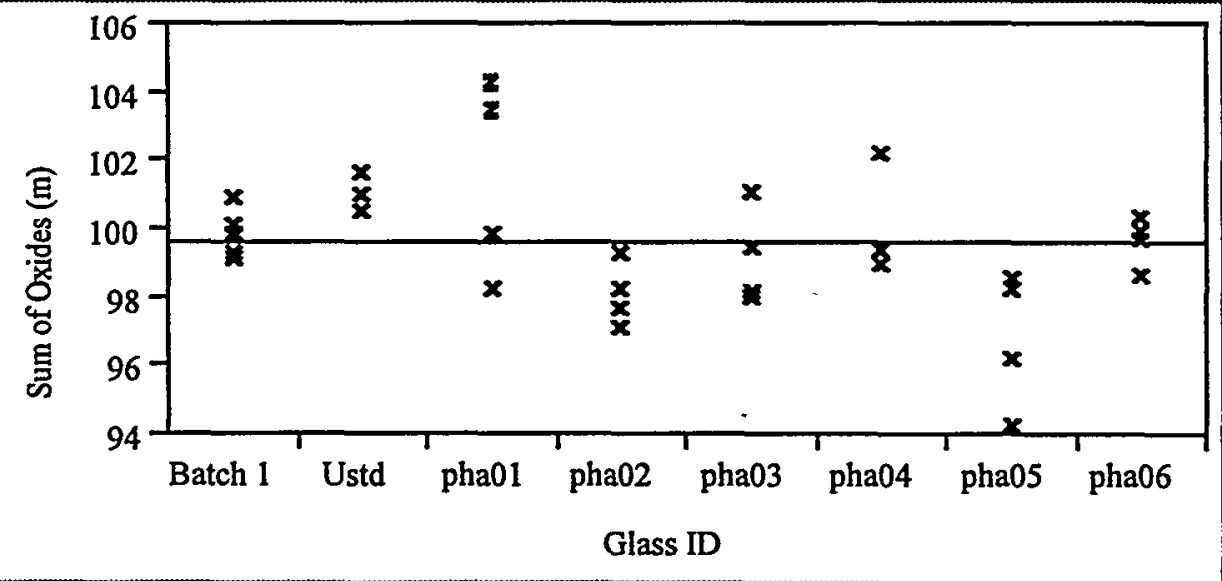


WSRC-TR-99-00292

Revision 0

Exhibit A.2: Peroxide Fusion Measurements of Glass Standards by Oxide (+ u-std; small square Batch I standard)

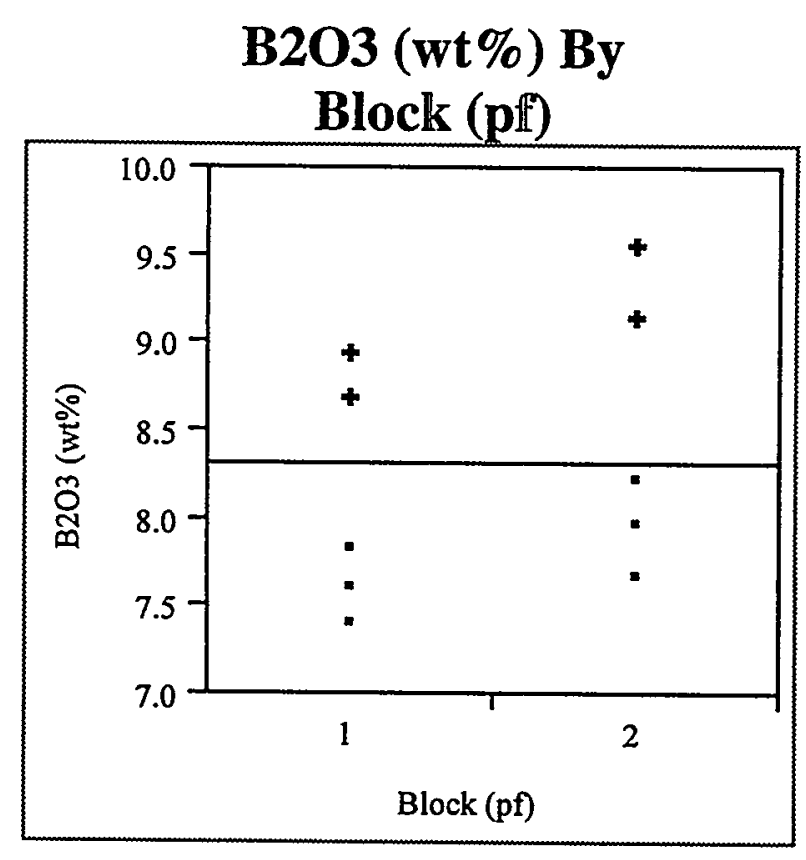

$\mathrm{SiO} 2 \mathrm{pf}(\mathrm{wt} \%) \mathrm{By}$

Block (pf)

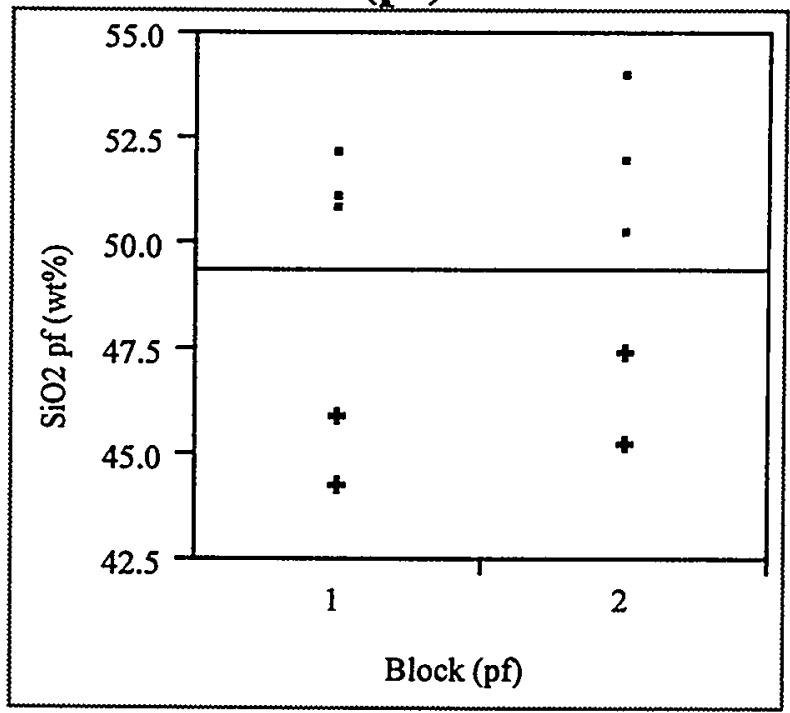

Ca pf (wt\%) By

Block (pf)

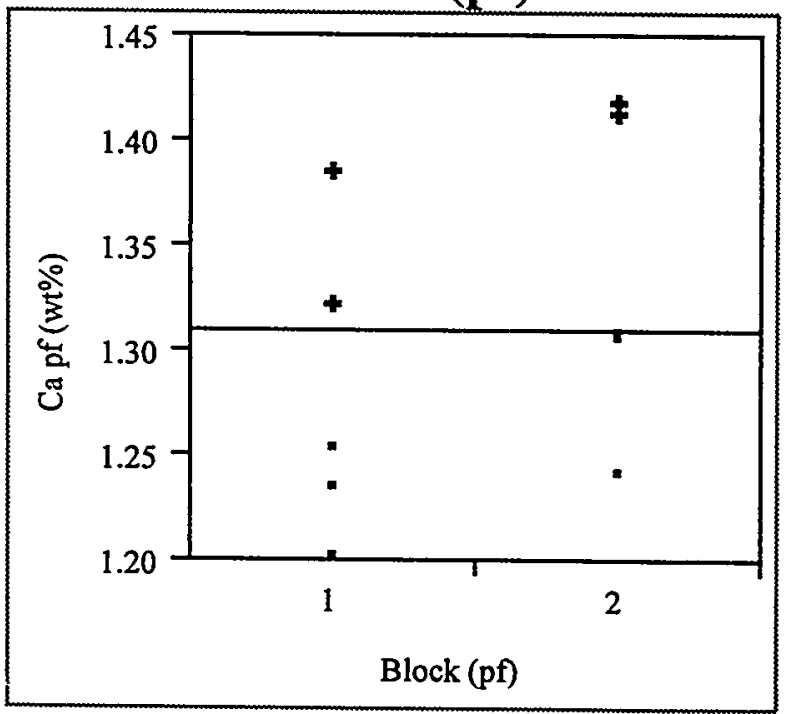


Exhibit A.3: Microwave Measurements of Glass Standards by Oxide (+ u-std; small square Batch 1 standard)

Al203 (wt\%) By Block (MW)

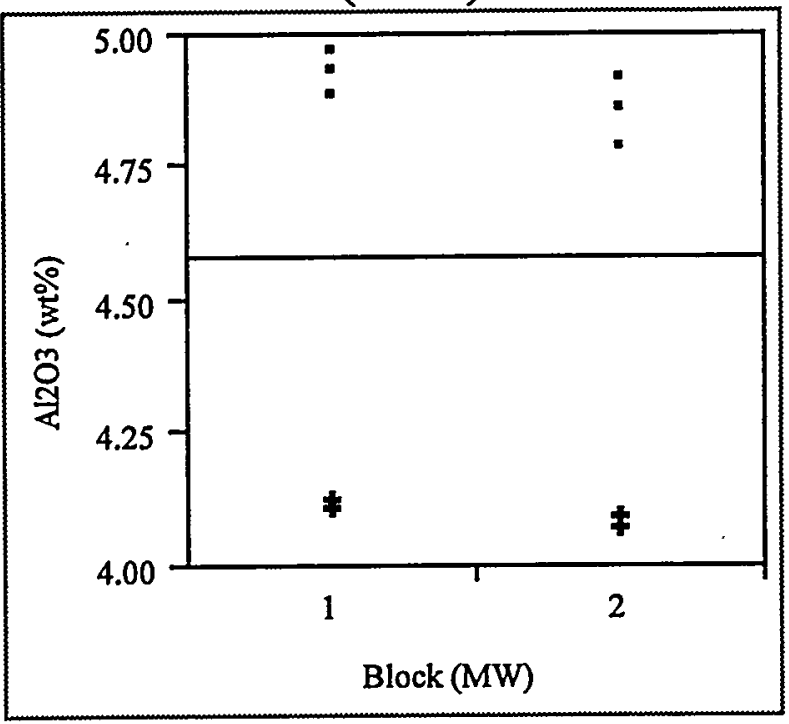

CaO MW (wt\%) By Block (MW)

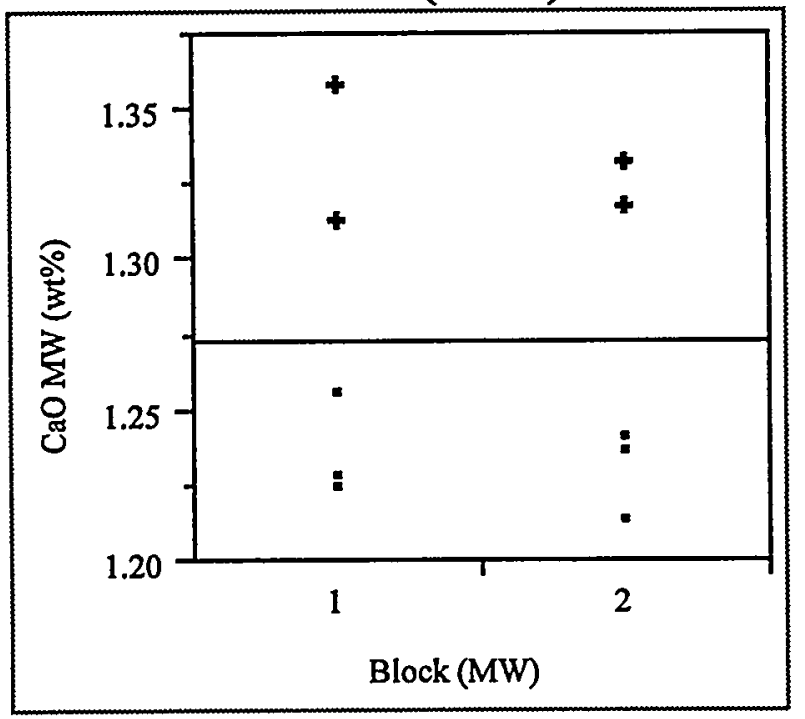

Cr2O3 (wt\%) By Block (MW)

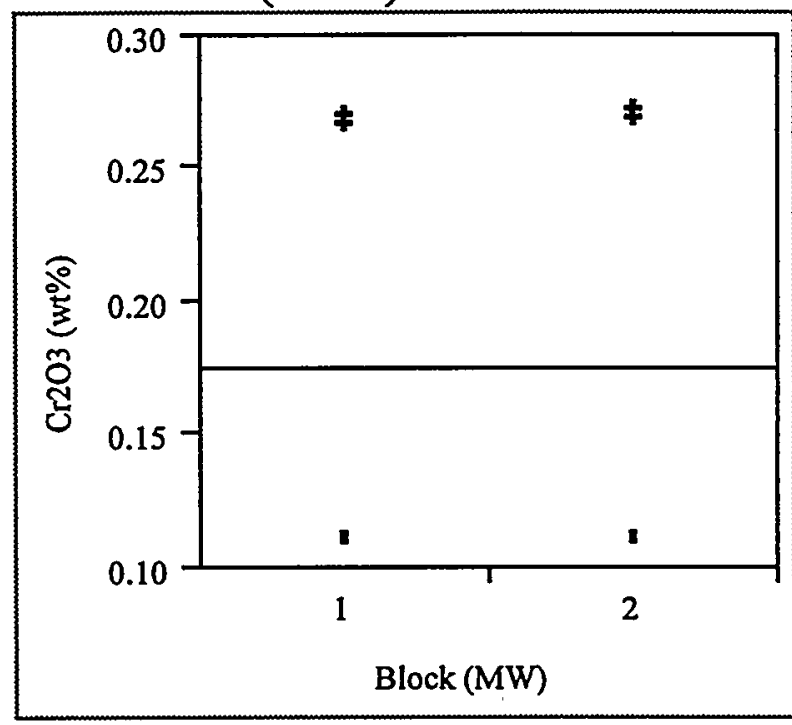

$\mathrm{CuO}($ wt\%) By Block (MW)

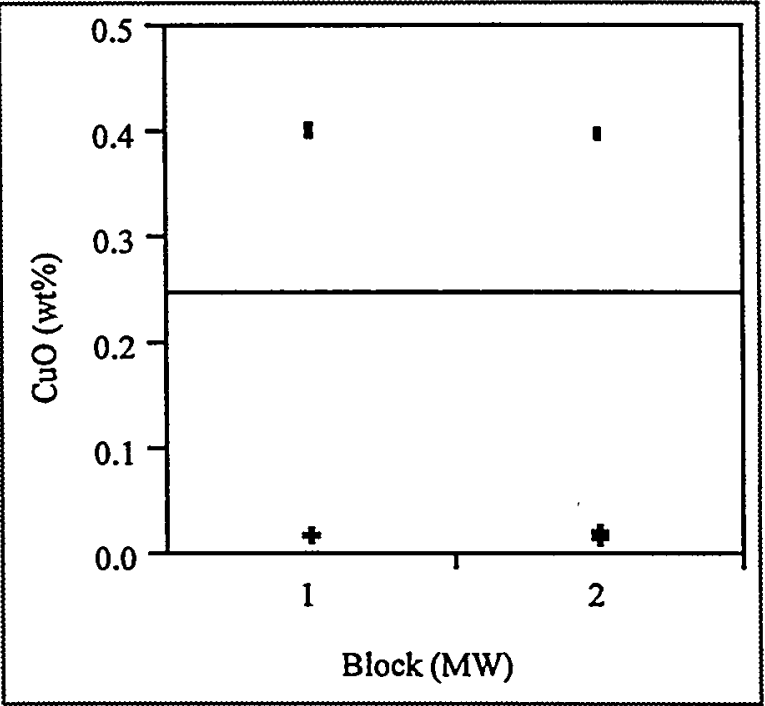


WSRC-TR-99-00292

Revision 0

Exhibit A.3: Microwave Measurements of Glass Standards by Oxide (+ u-std; small square Batch 1 standard)

(continued)

Fe2O3 (wt\%) By Block (MW)

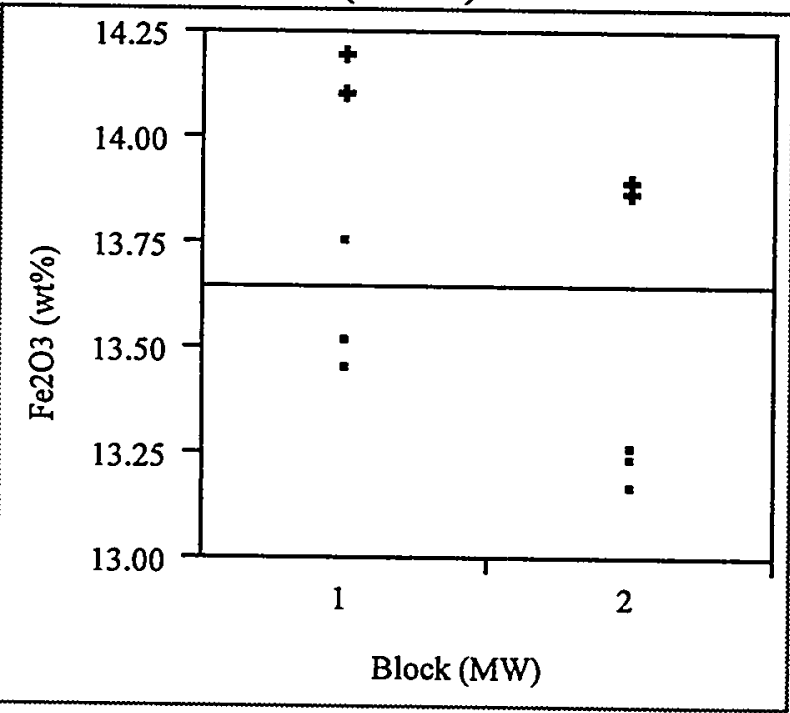

K2O (wt\%) By Block

(MW)

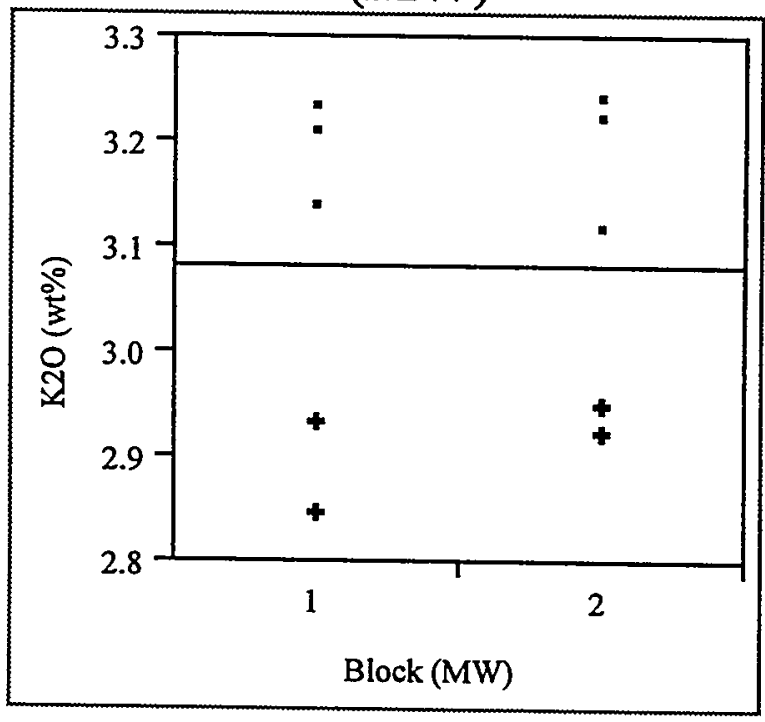

Li2O (wt\%) By Block

(MW)

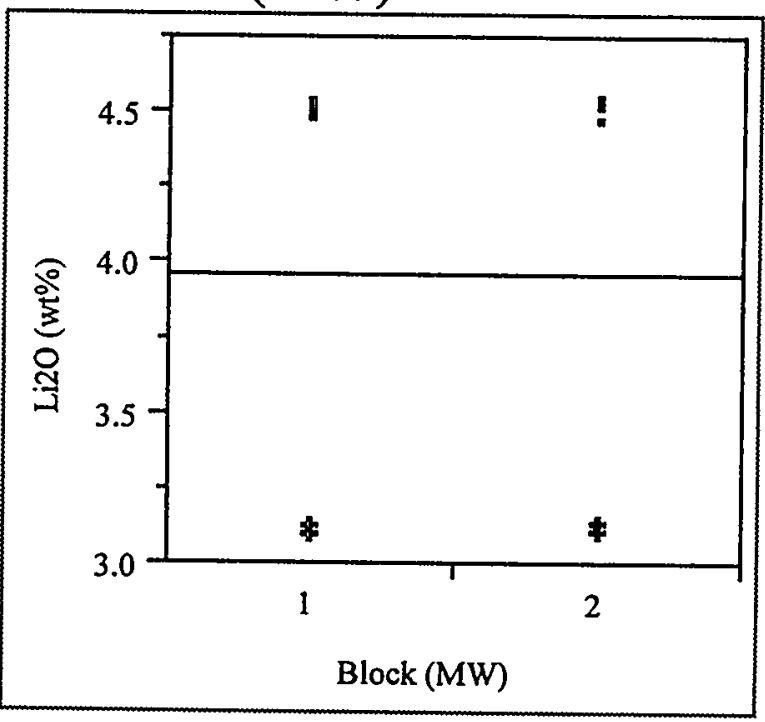

MgO (wt\%) By Block

(MW)

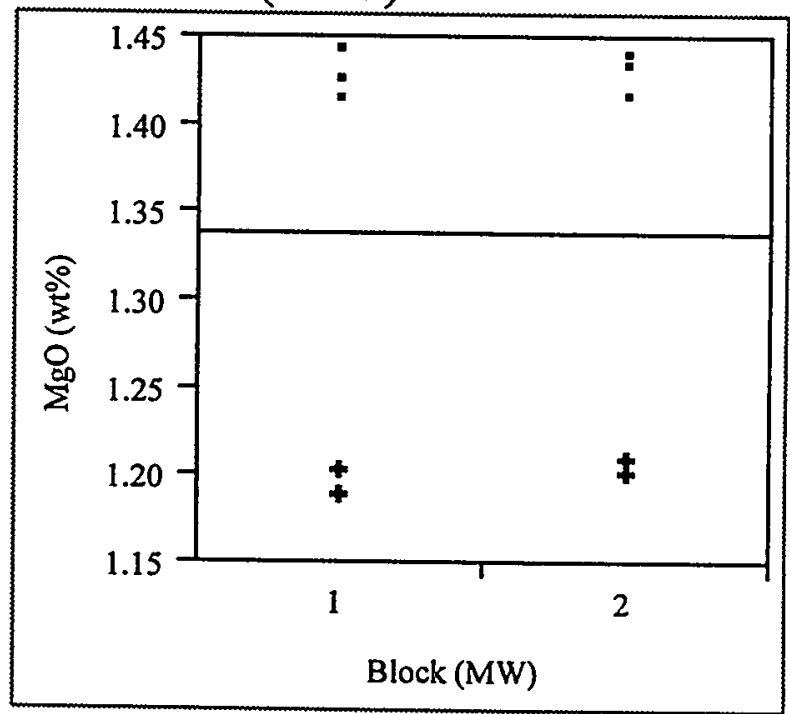


Exhibit A.3: Microwave Measurements of Glass Standards by Oxide (+ u-std; small square Batch 1 standard) (continued)

MnO (wt\%) By Block

(MW)

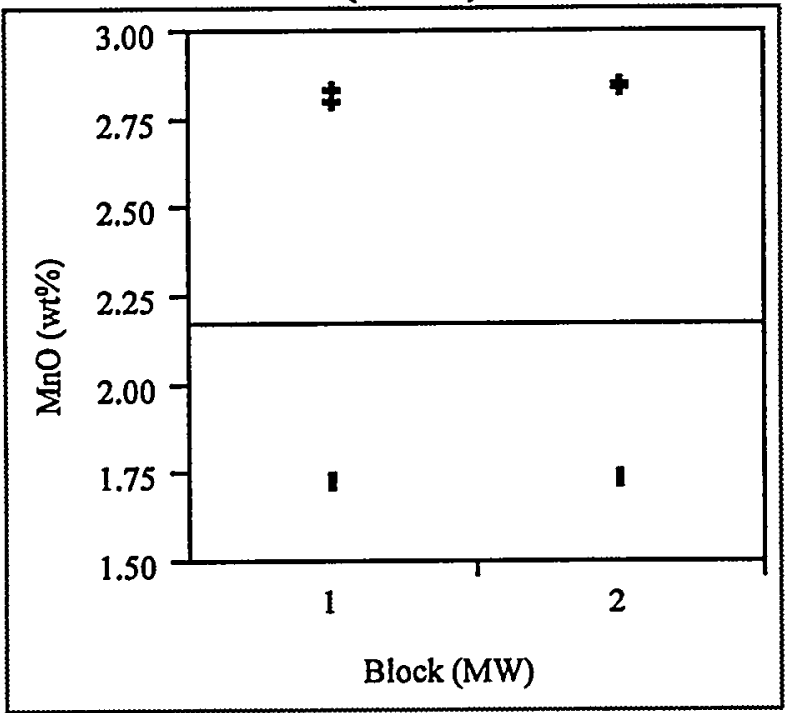

$\mathrm{Na2O}(w t \%)$ By Block (MW)

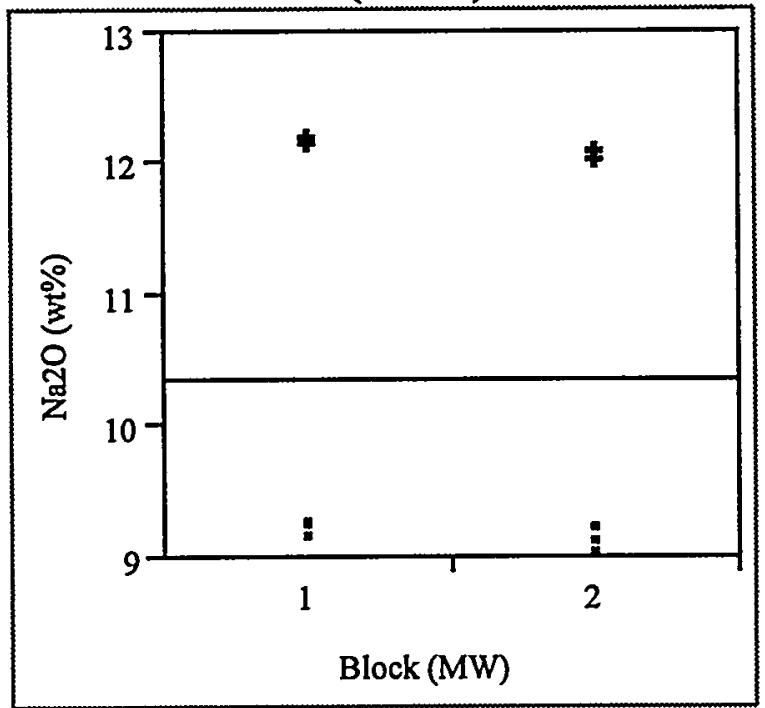

NiO (wt\%) By Block (MW)

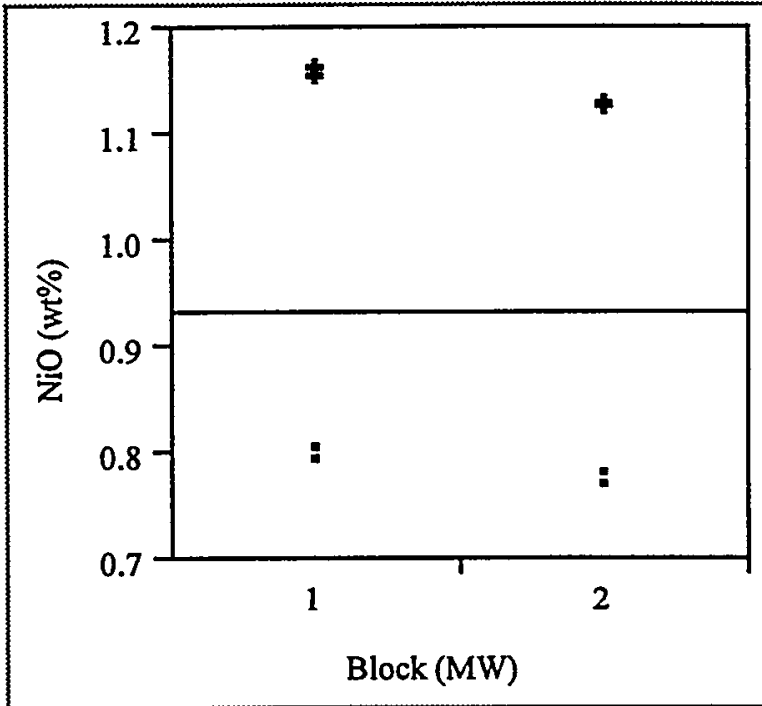

$\mathrm{SiO} 2 \mathrm{MW}(\mathrm{wt} \%)$ By Block (MW)

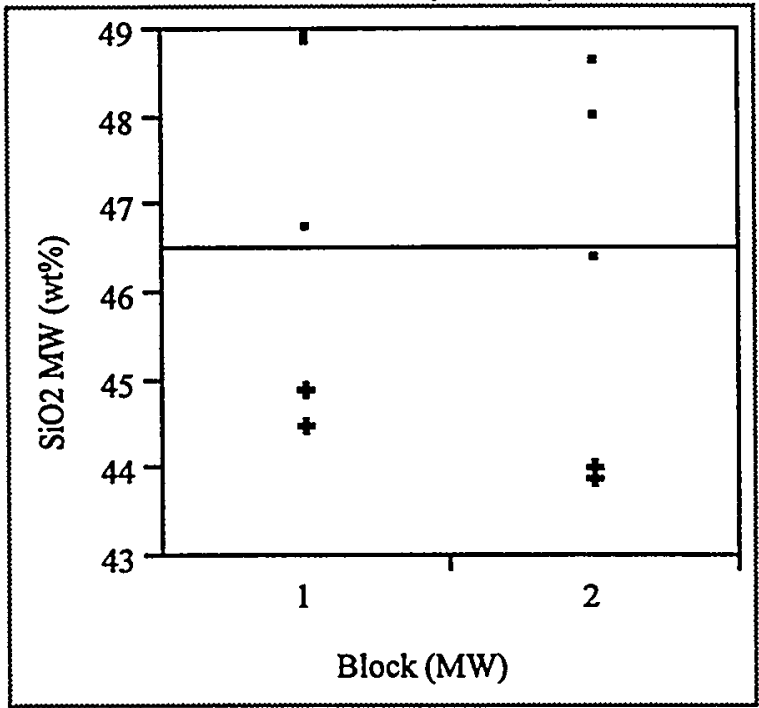


WSRC-TR-99-00292

Revision 0

Exhibit A.3: Microwave Measurements of Glass Standards by Oxide

(+ u-std; small square Batch 1 standard)

(continued)

TiO2 (wt\%) By Block (MW)

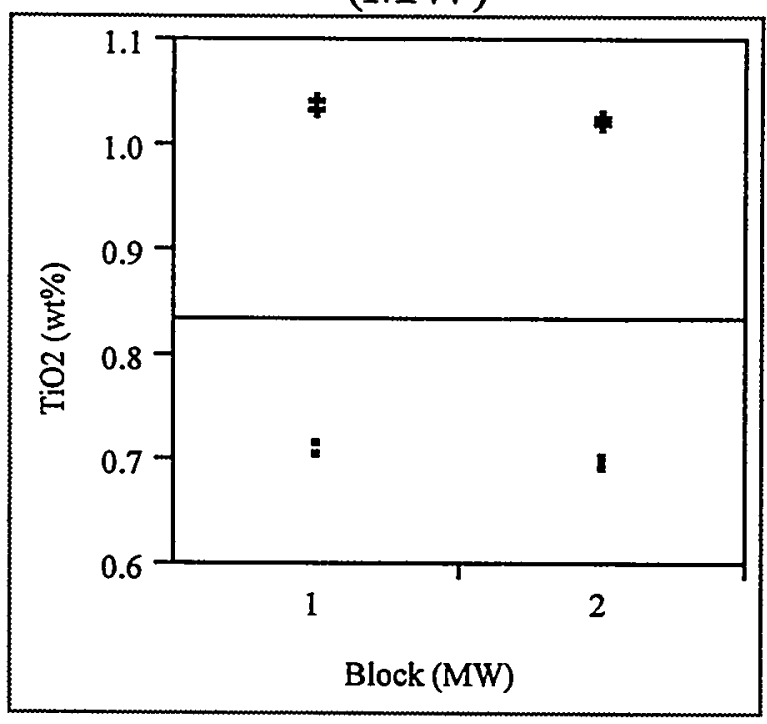

U3O8 (wt\%) By Block

(MW)

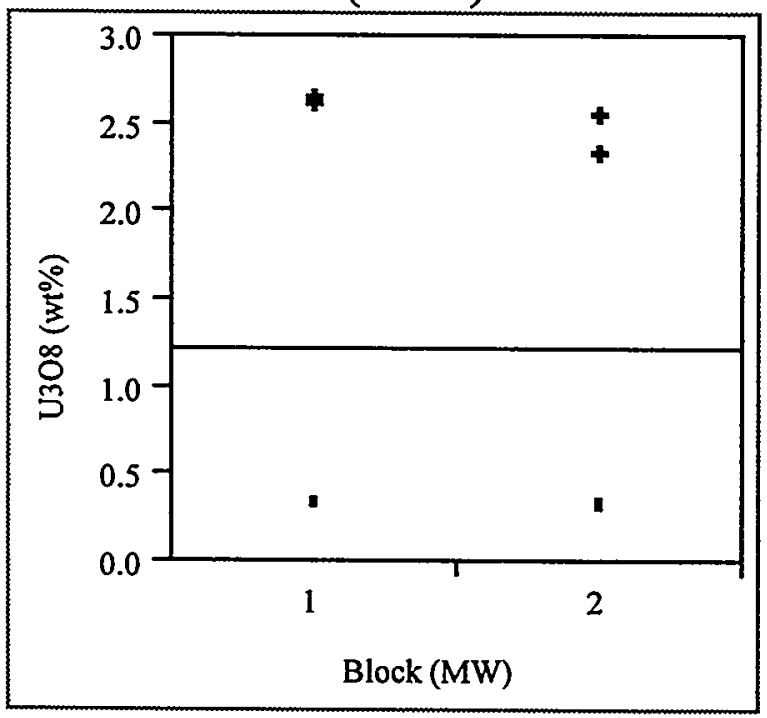

ZrO2 (wt\%) By Block (MW)

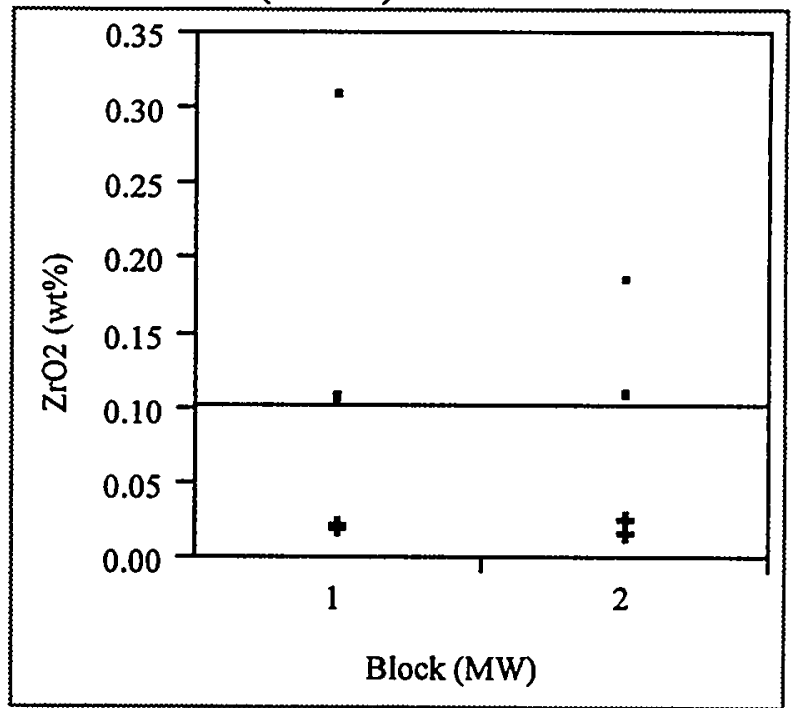


Exhibit A.4: Comparisons of Measurements versus Target Compositions (concentrations in weight percents) Al203

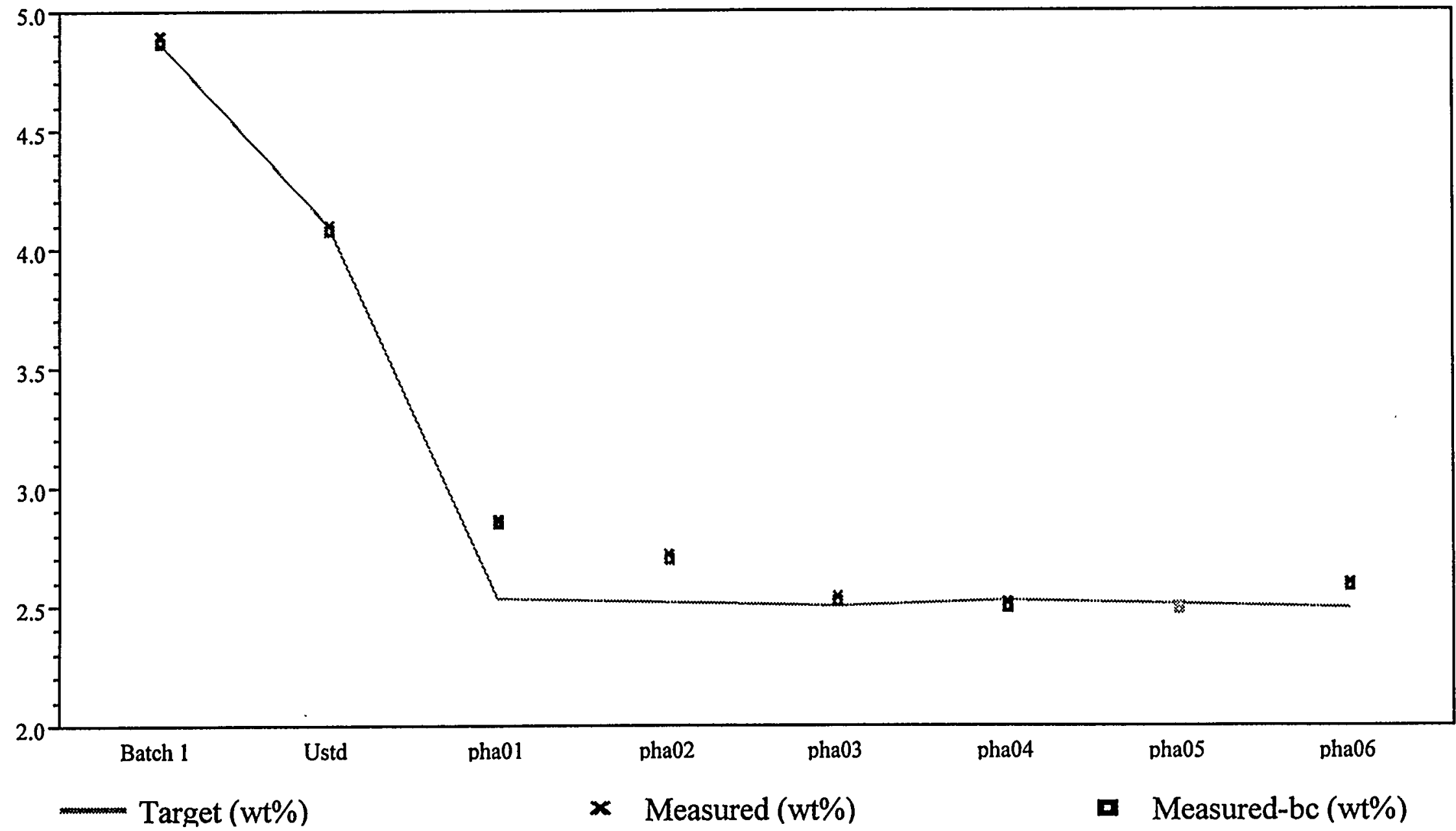



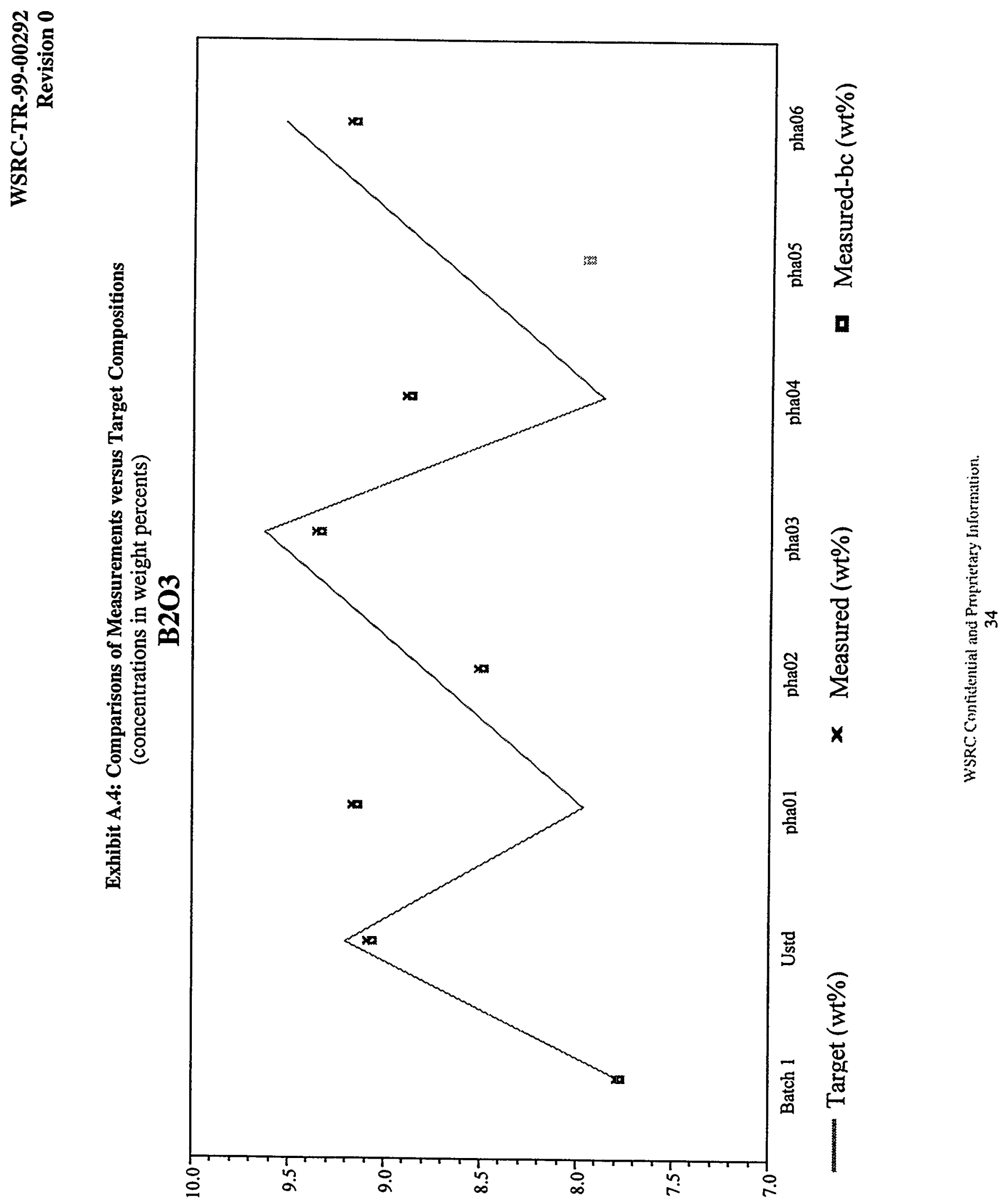
Exhibit A.4: Comparisons of Measurements versus Target Compositions (concentrations in weight percents)

$\mathrm{CaO}$

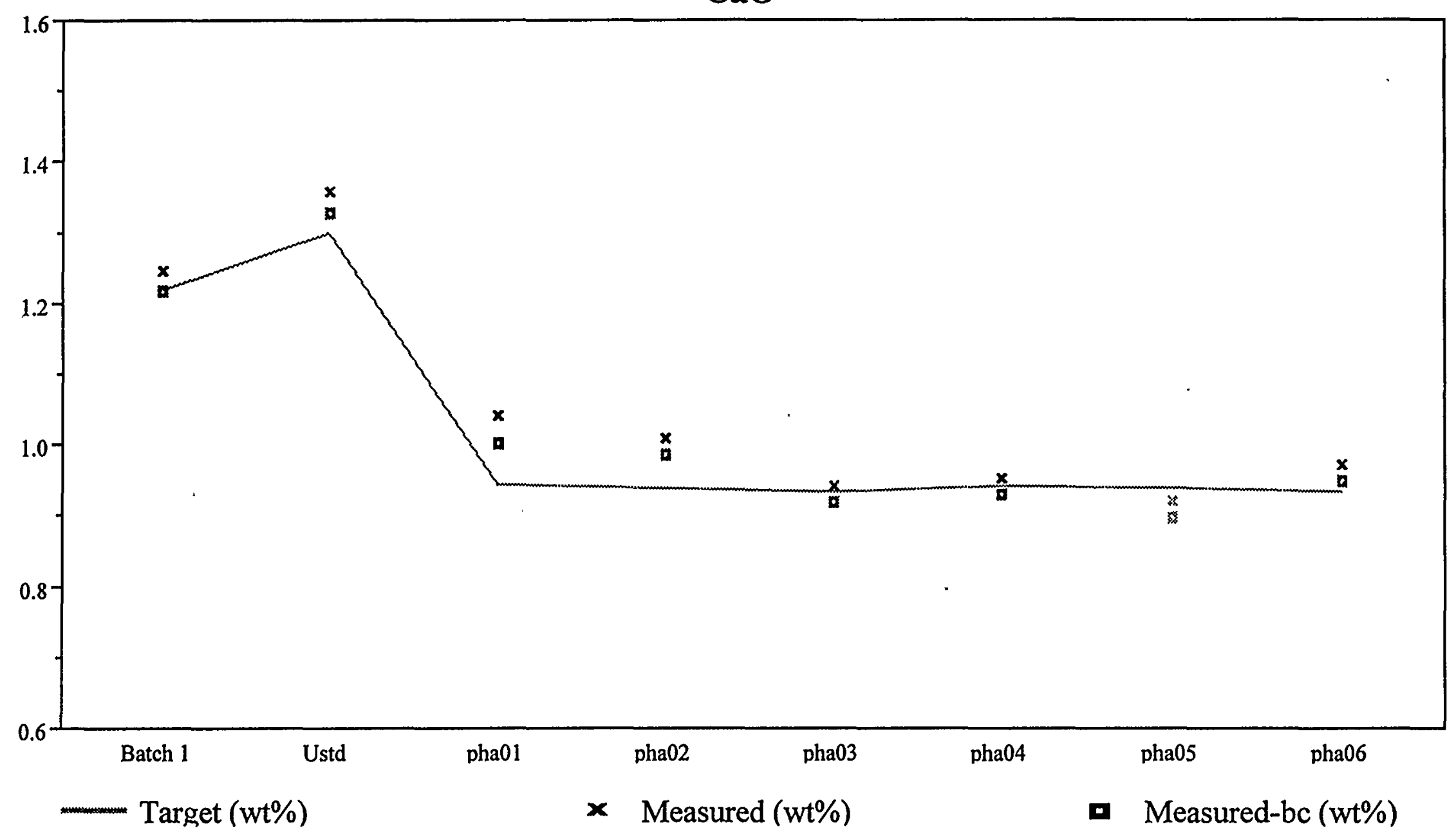


Exhibit A.4: Comparisons of Measurements versus Target Compositions (concentrations in weight percents)

$\mathrm{Cr} 2 \mathrm{O3}$

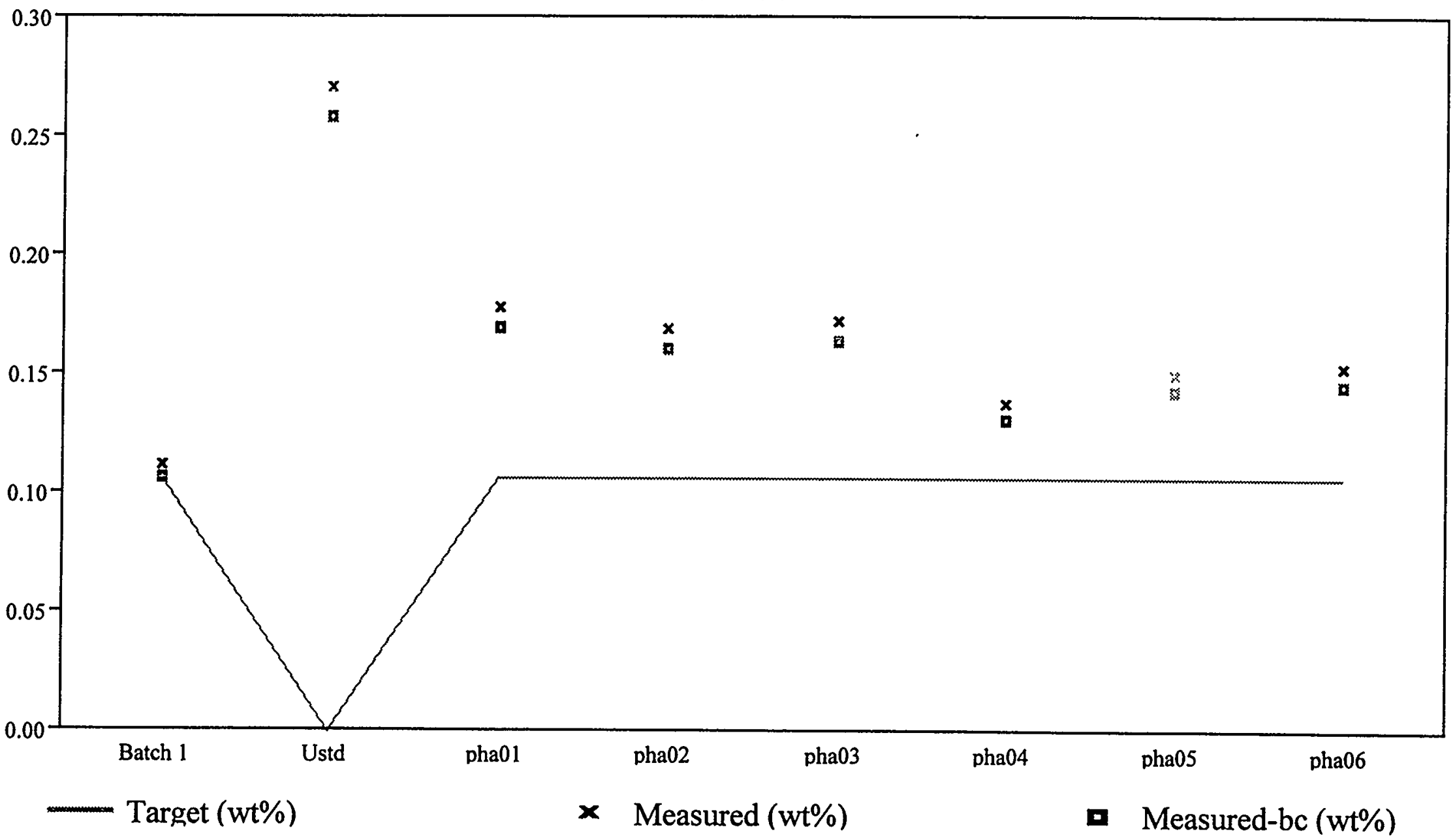


WSRC-TR-99-00292

Revision 0

\section{Exhibit A.4: Comparisons of Measurements versus Target Compositions}

(concentrations in weight percents)

$\mathrm{CuO}$

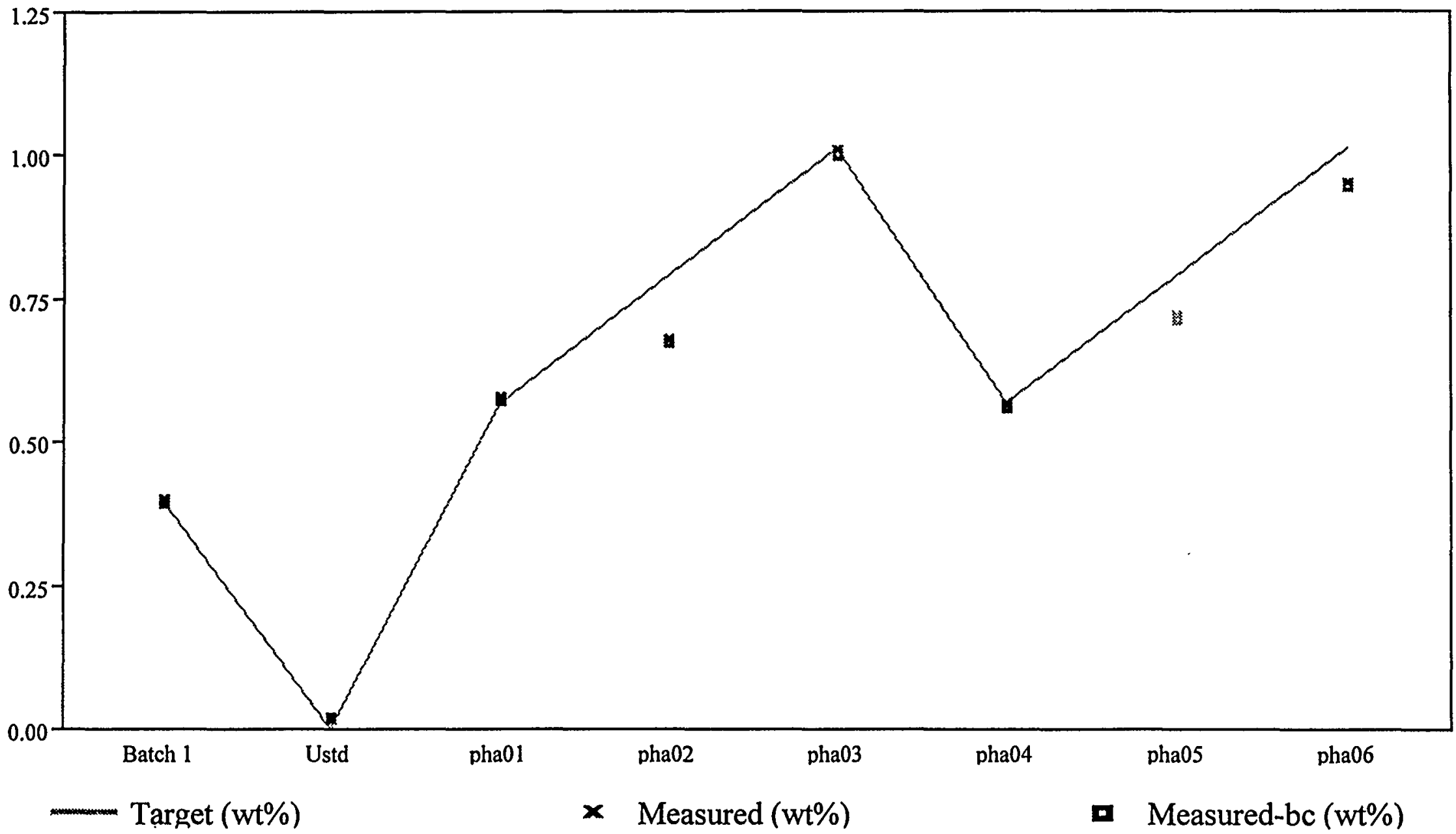


Exhibit A.4: Comparisons of Measurements versus Target Compositions (concentrations in weight percents)

$\mathrm{Fe} 2 \mathrm{O3}$

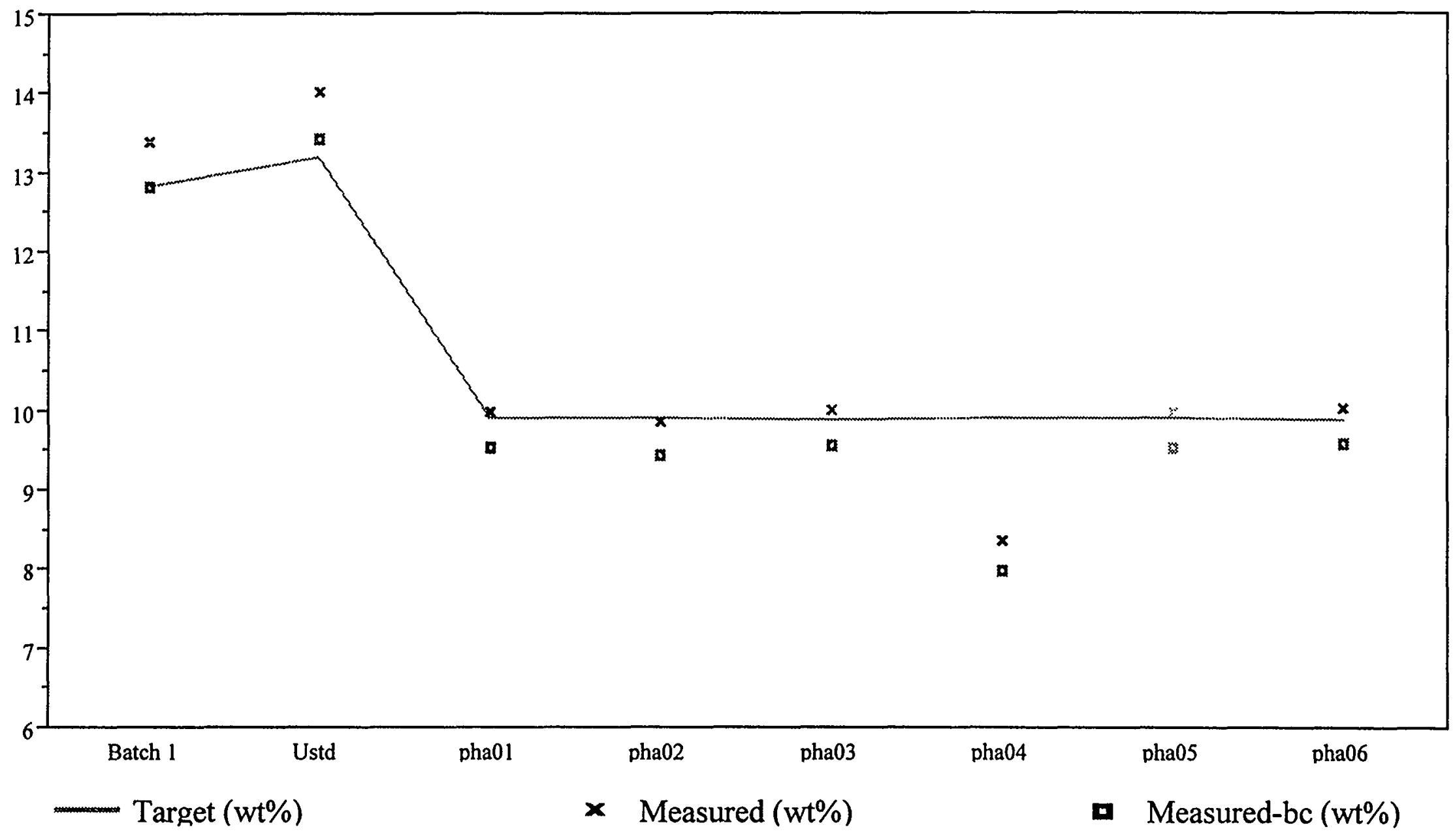



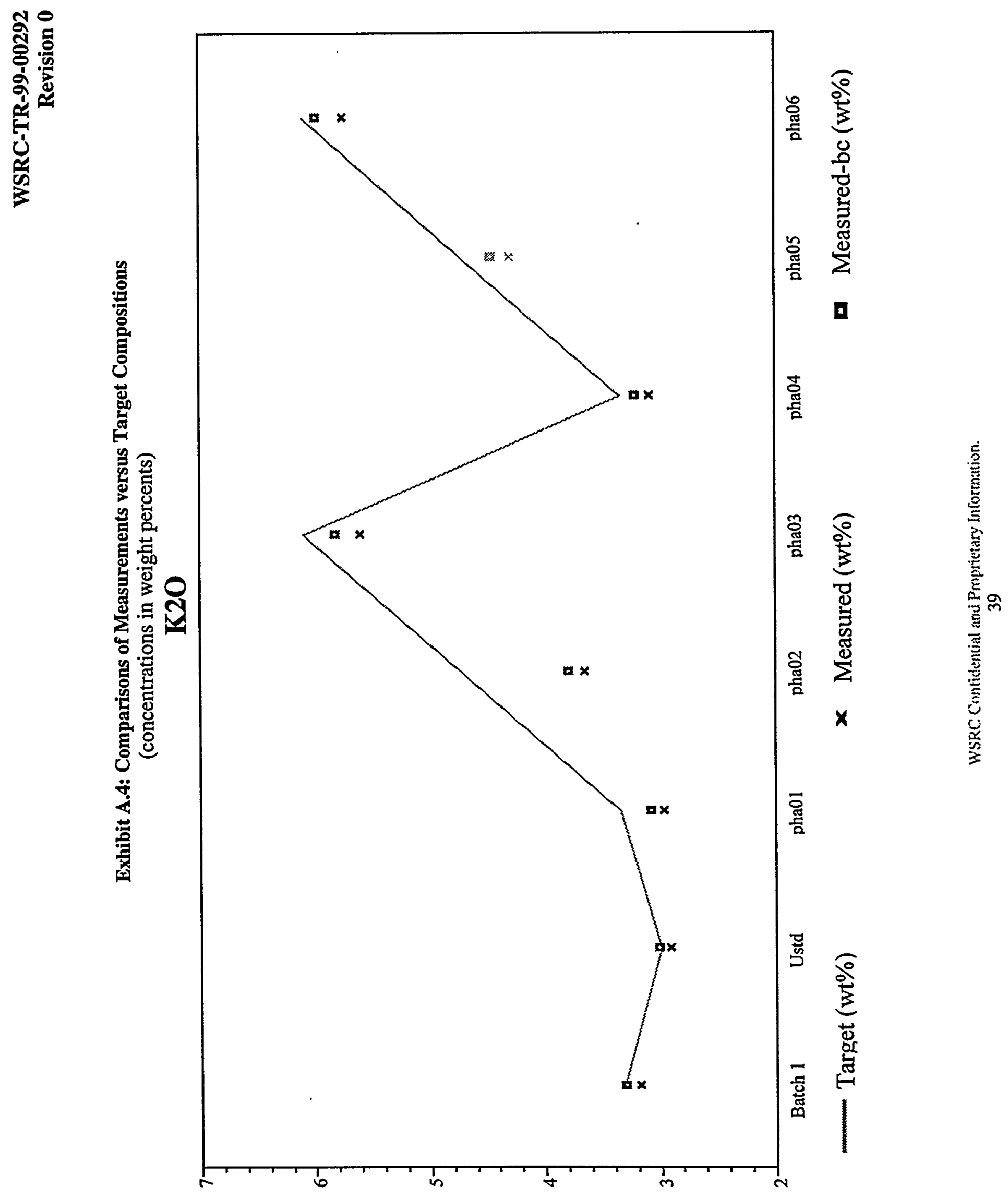
Exhibit A.4: Comparisons of Measurements versus Target Compositions (concentrations in weight percents)

Li2O

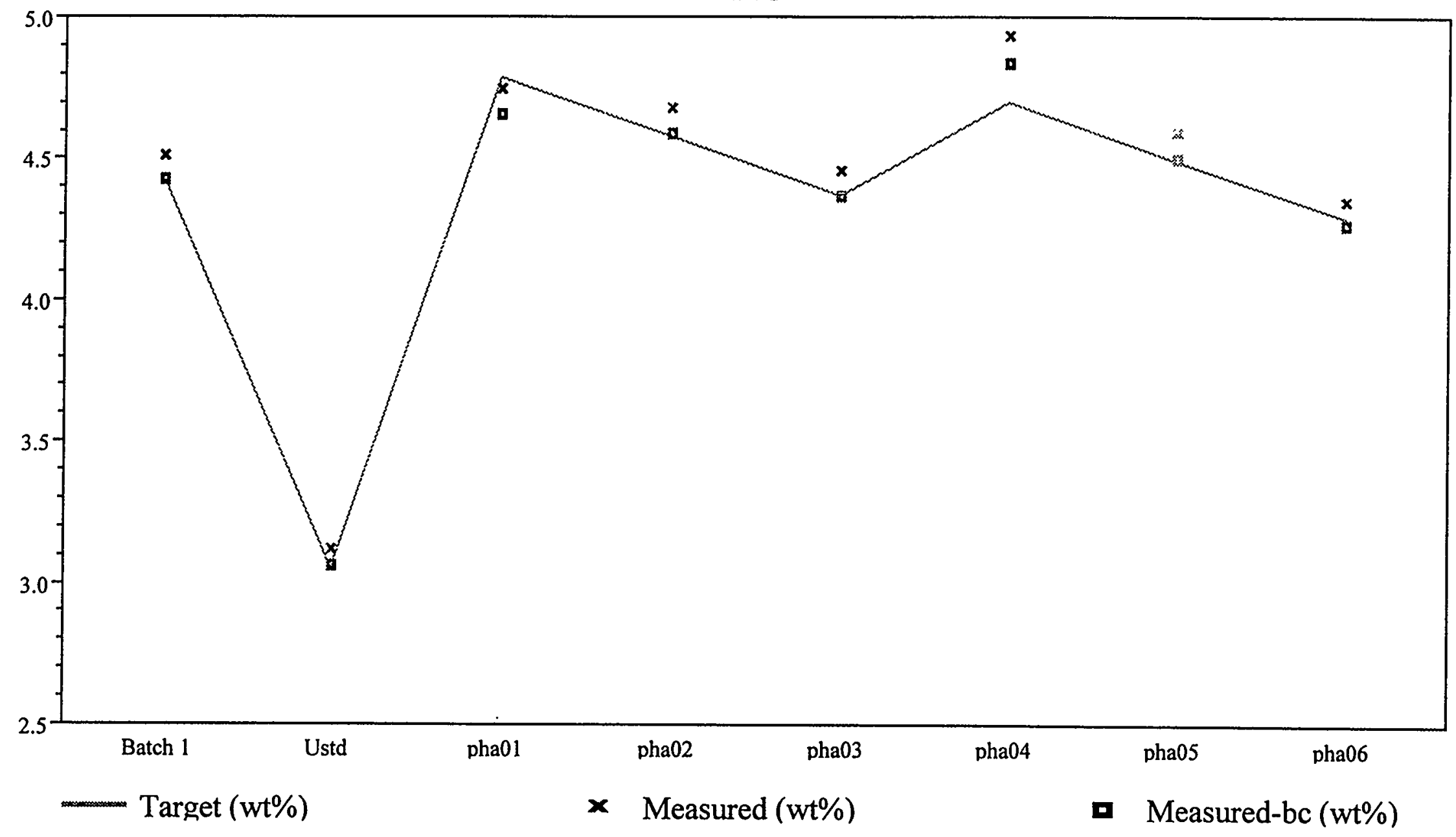


Exhibit A.4: Comparisons of Measurements versus Target Compositions

(concentrations in weight percents)

$\mathrm{MgO}$

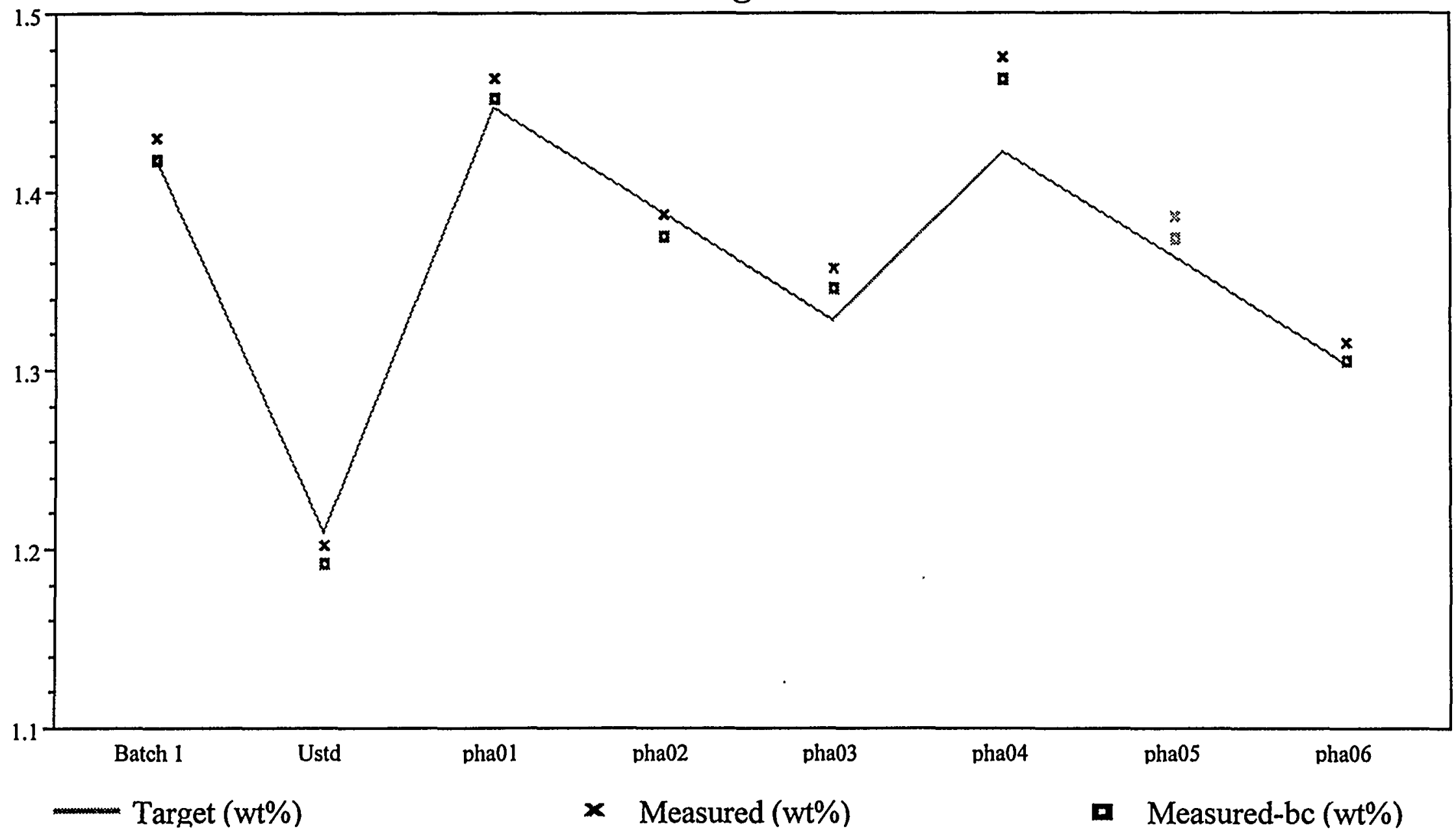

WSRC. Contikential and Proprictary Information 
Exhibit A.4: Comparisons of Measurements versus Target Compositions

(concentrations in weight percents)

MnO

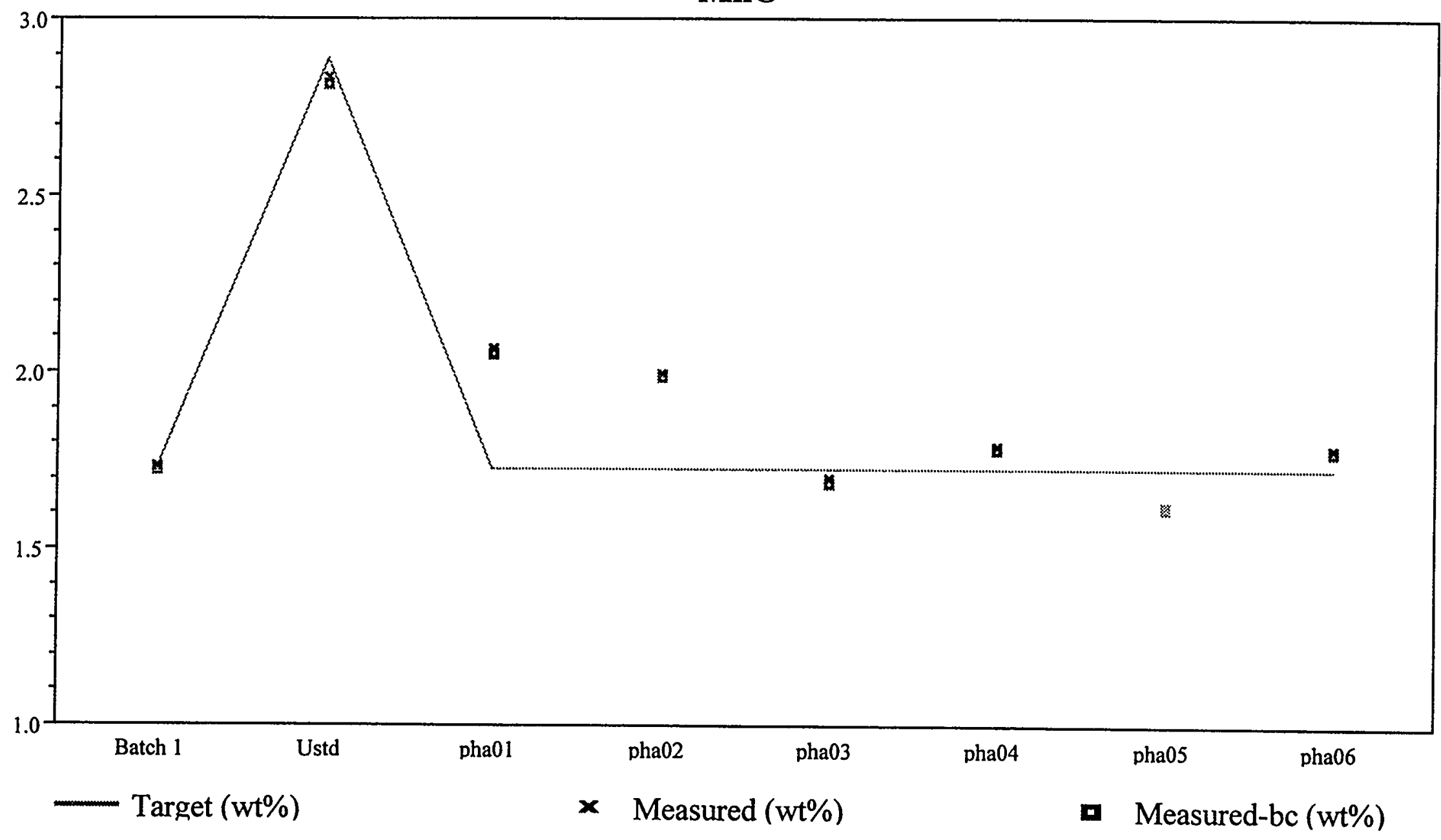


Exhibit A.4: Comparisons of Measurements versus Target Compositions (concentrations in weight percents)

$\mathrm{Na} 2 \mathrm{O}$

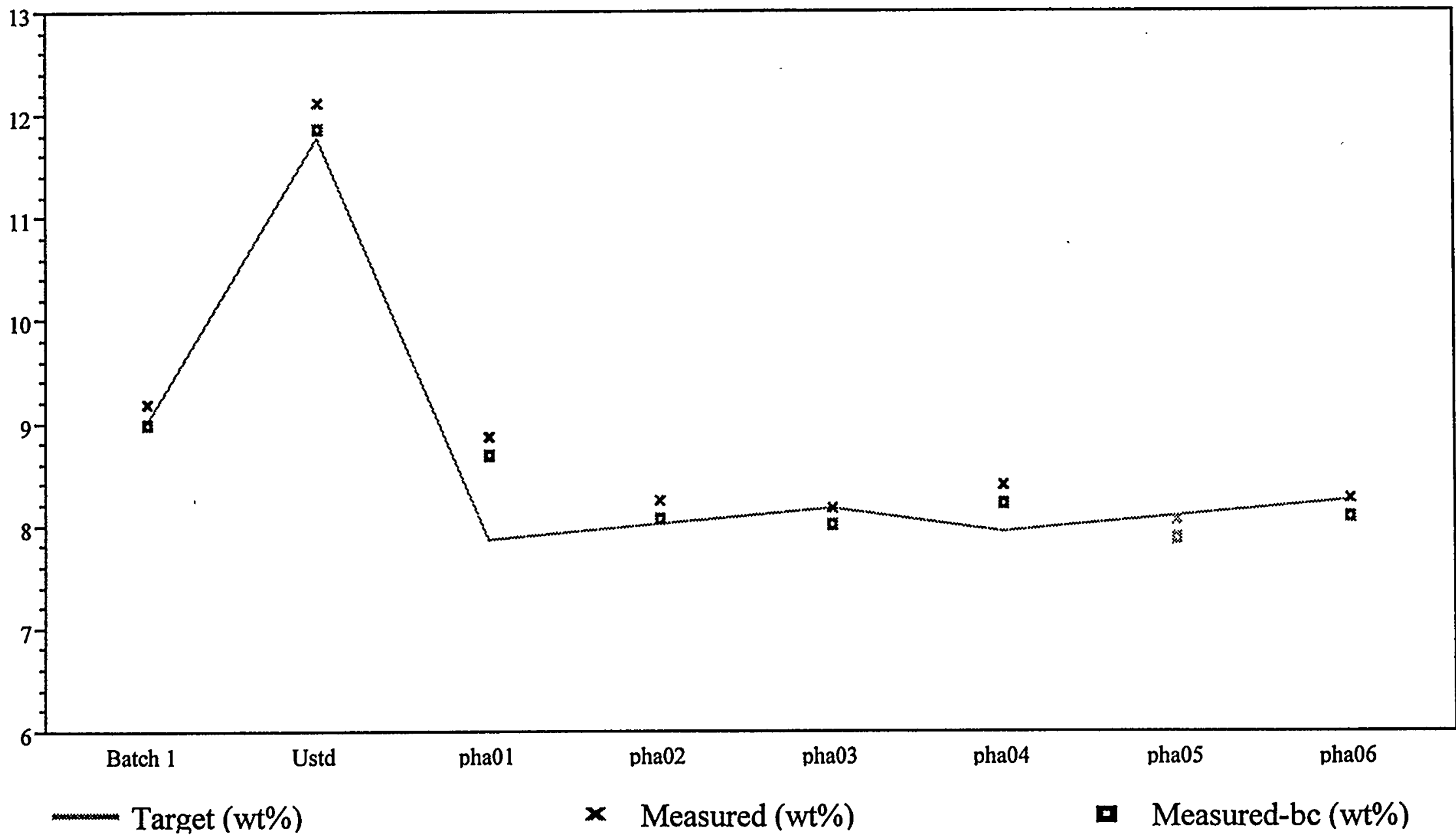


Exhibit A.4: Comparisons of Measurements versus Target Compositions (concentrations in weight percents)

$\mathrm{NiO}$

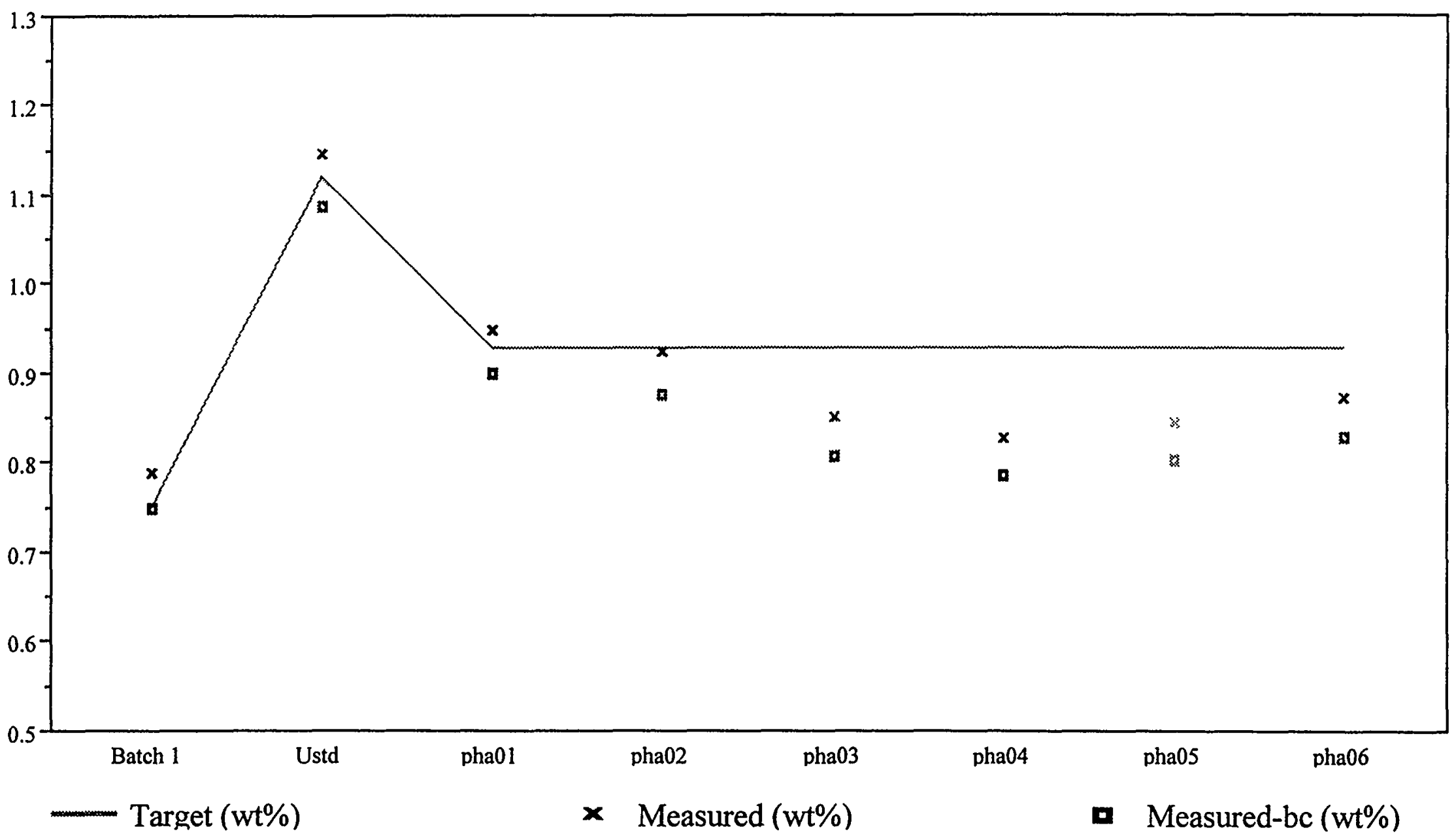


Exhibit A.4: Comparisons of Measurements versus Target Compositions (concentrations in weight percents)

$\mathrm{SiO} 2$

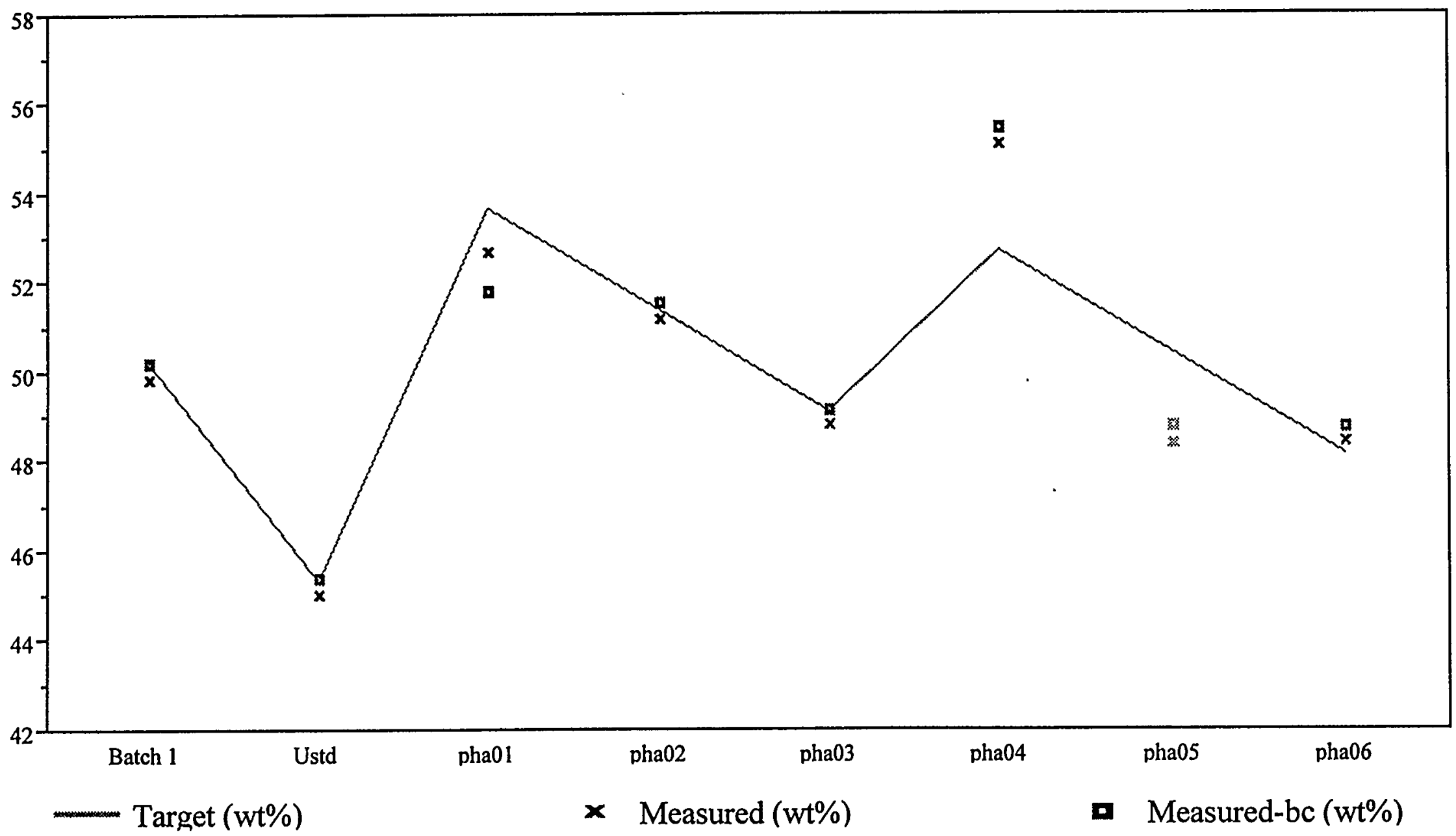


Exhibit A.4: Comparisons of Measurements versus Target Compositions

(concentrations in weight percents)

\section{TiO2}

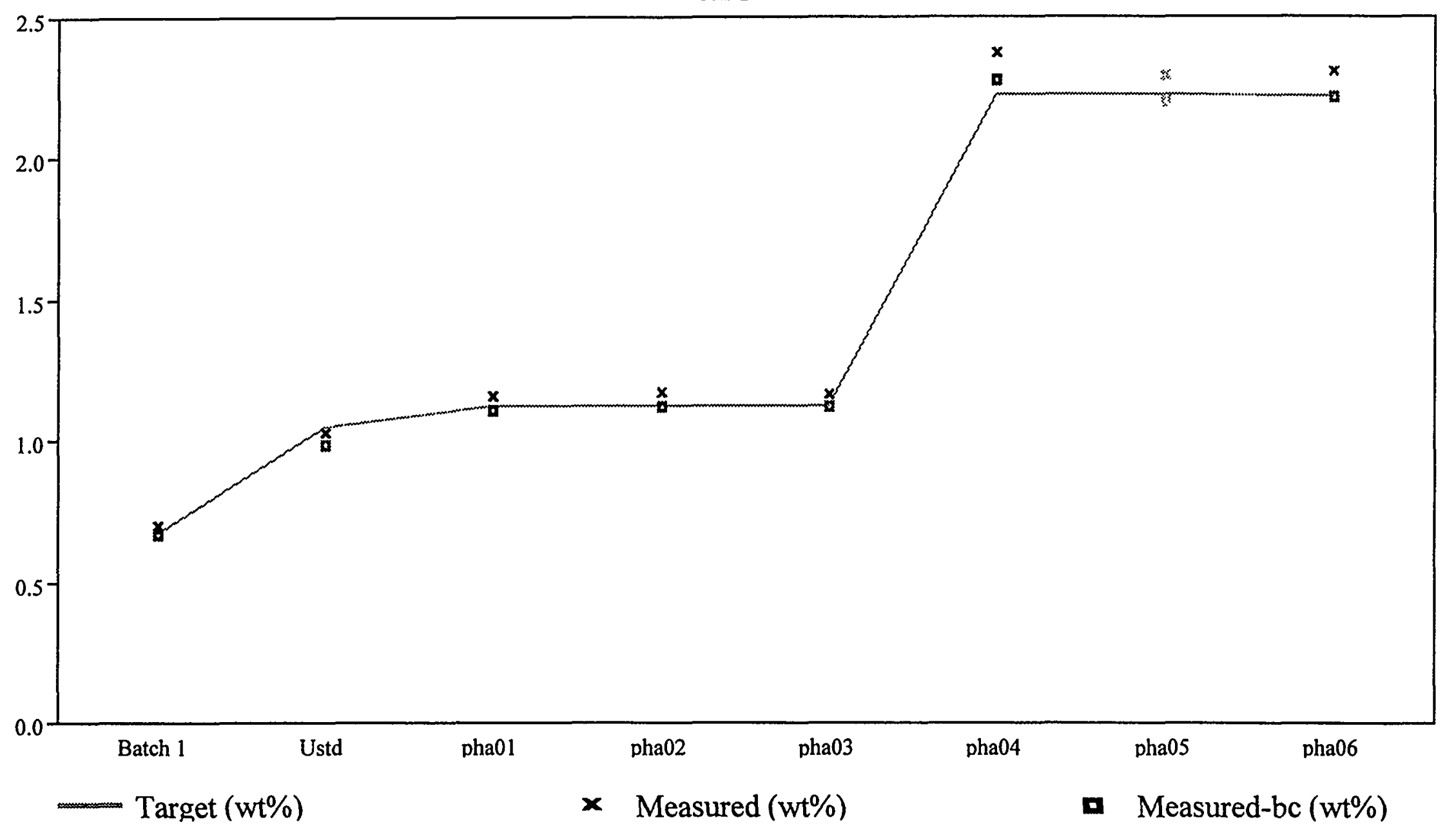



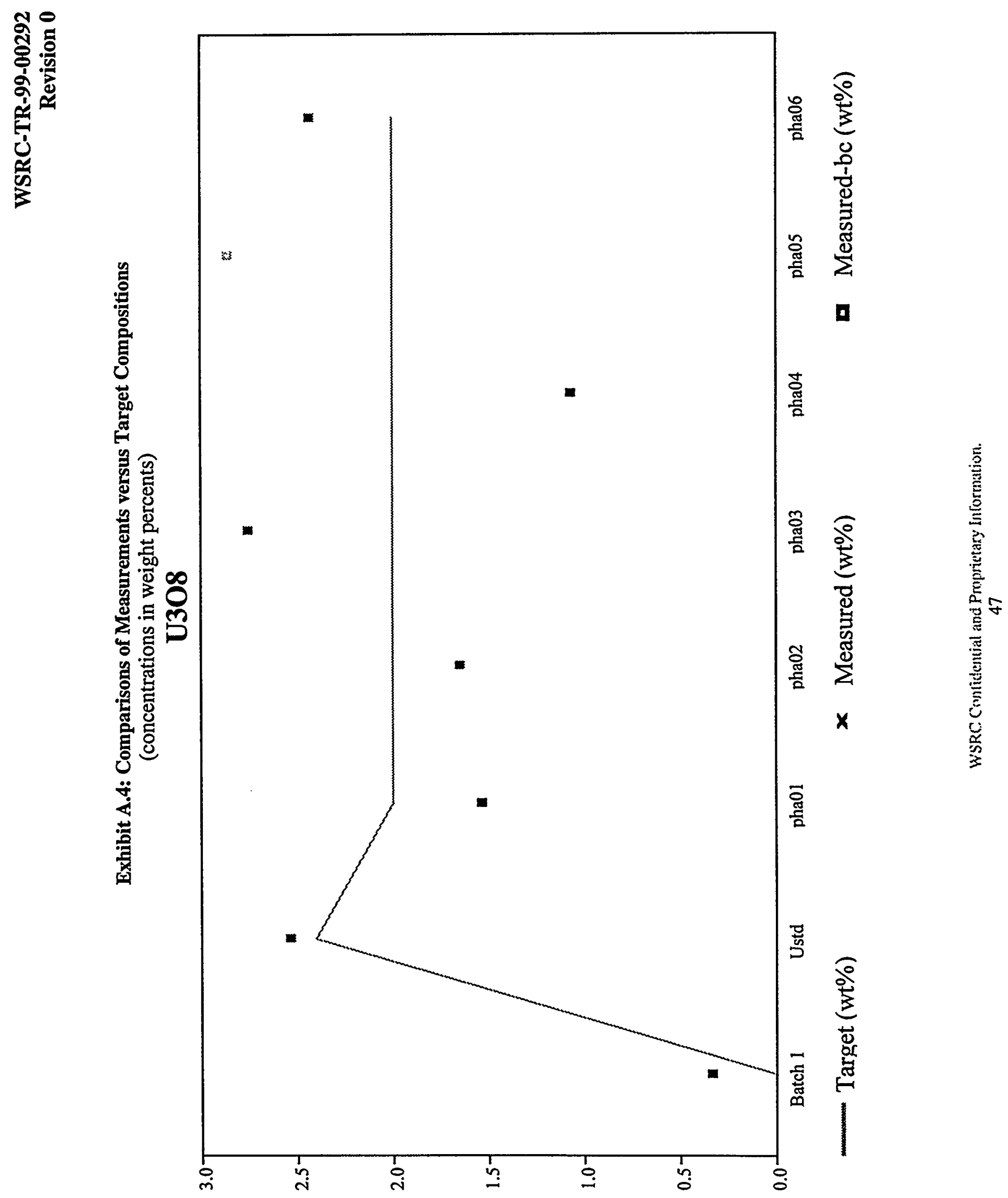
Exhibit A.4: Comparisons of Measurements versus Target Compositions (concentrations in weight percents)

$\mathrm{ZrO2}$

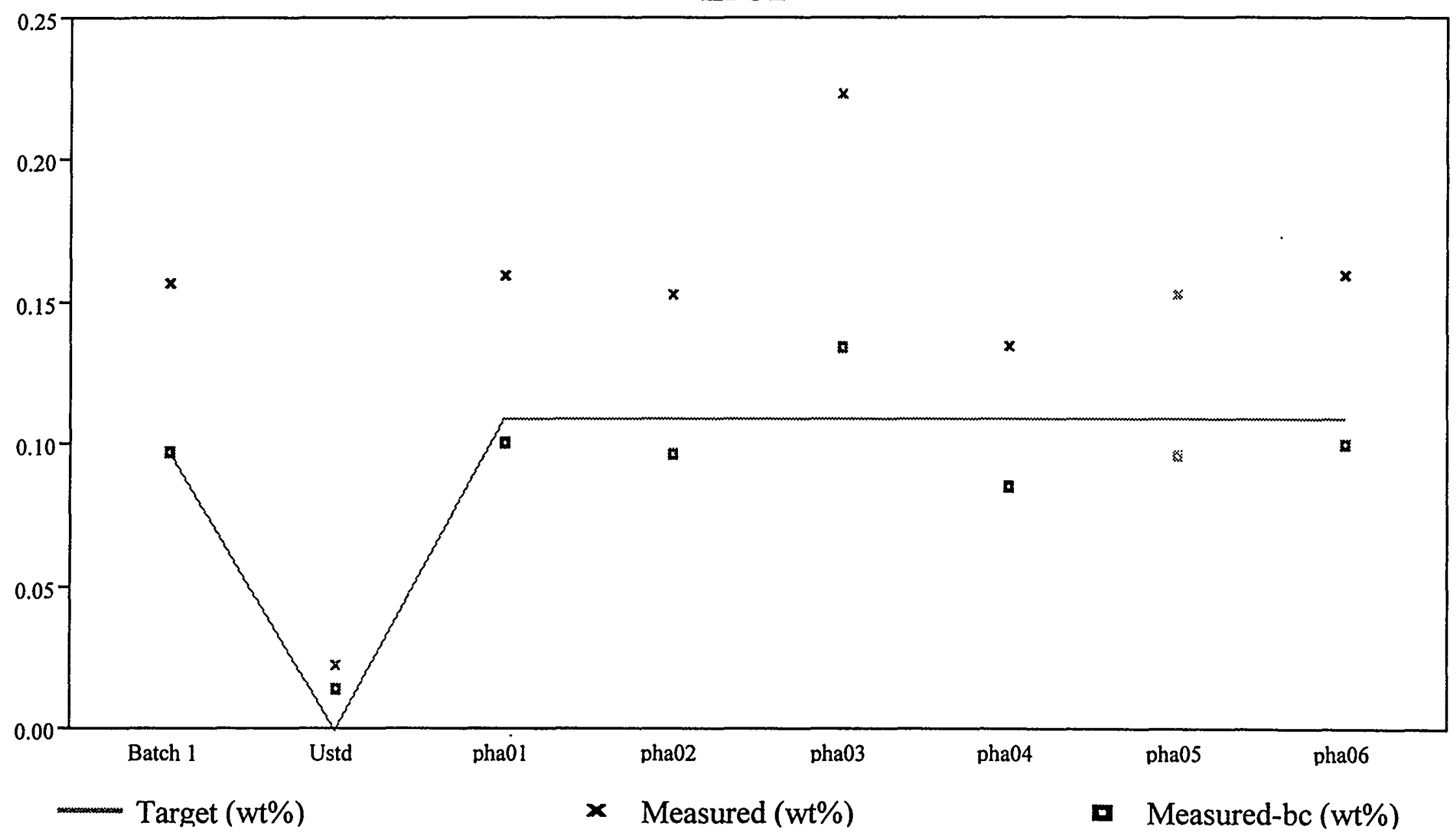


Exhibit A.4: Comparisons of Measurements versus Target Compositions

(concentrations in weight percents)

Sum of Oxides

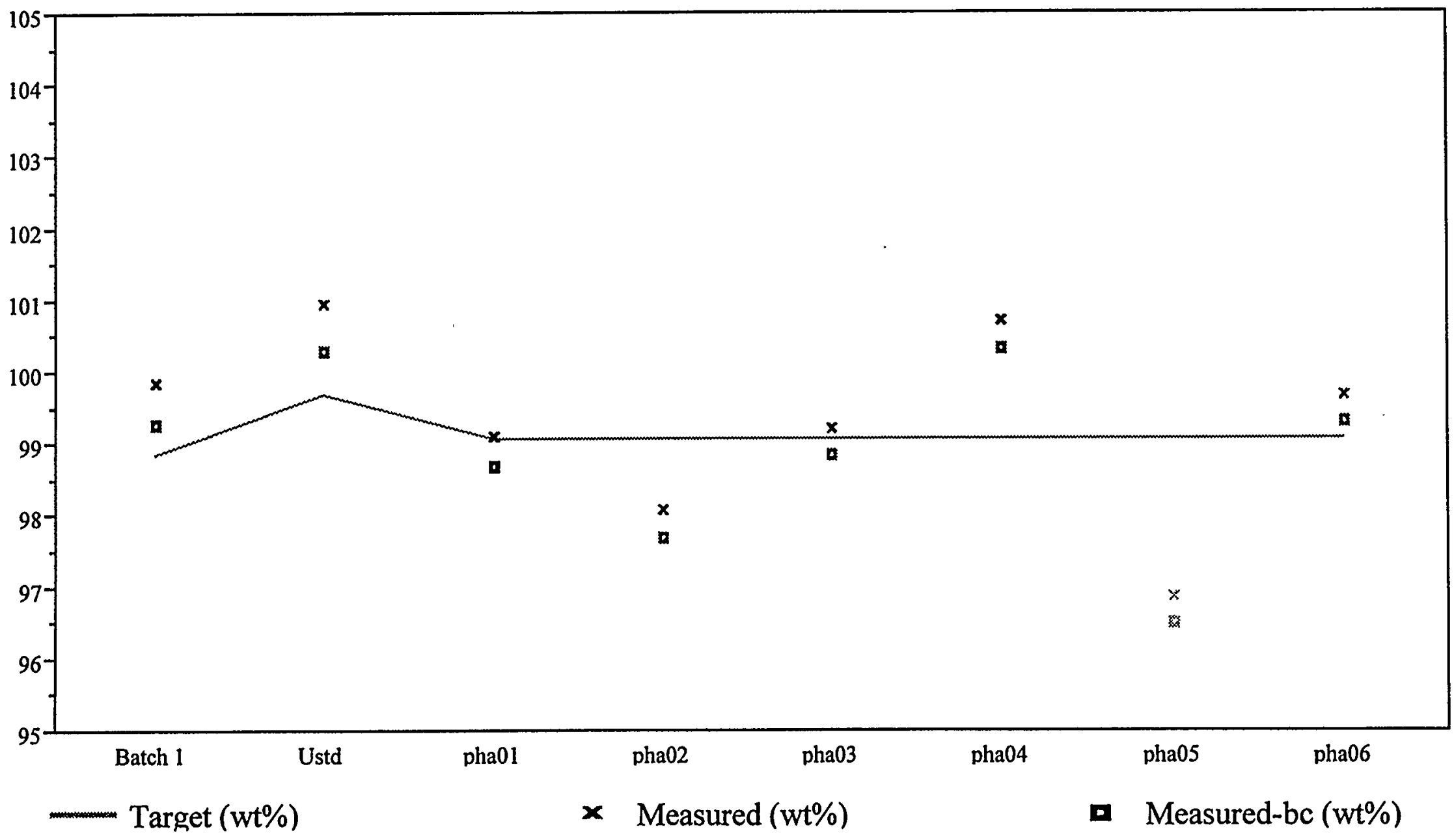


Exhibit A.5: Plots of the Leachate Concentrations by Sample ID by Element (with and without the EA and blank samples)

B (ppm) By Sample ID
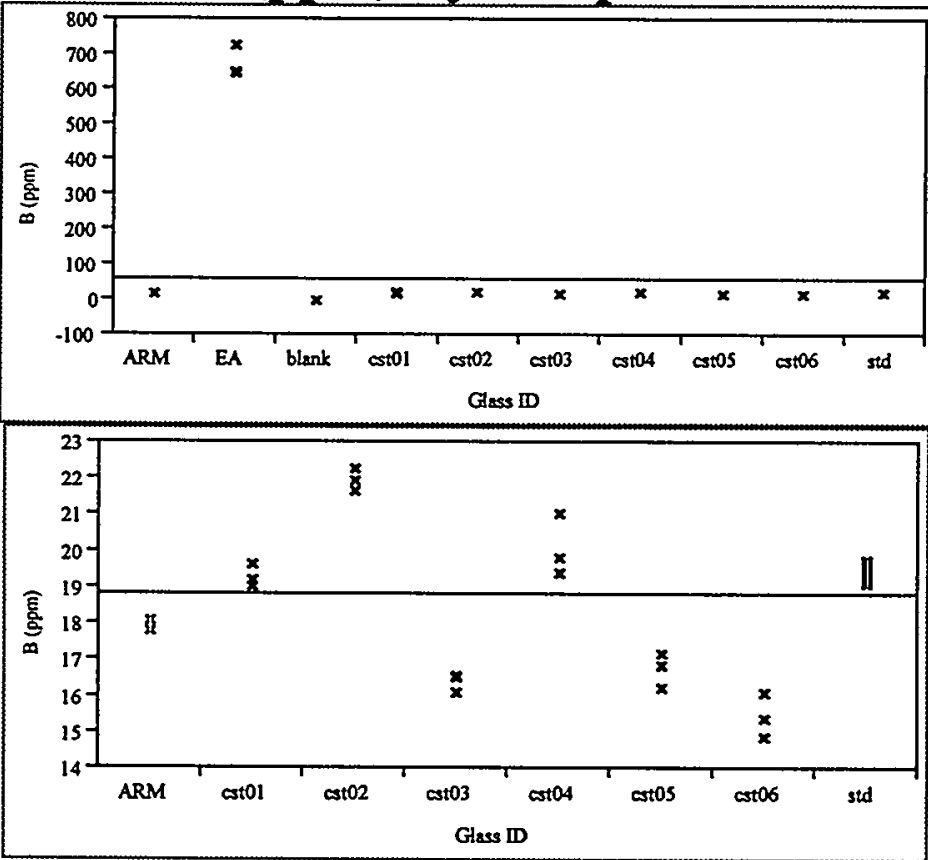

Si (ppm) By Sample ID

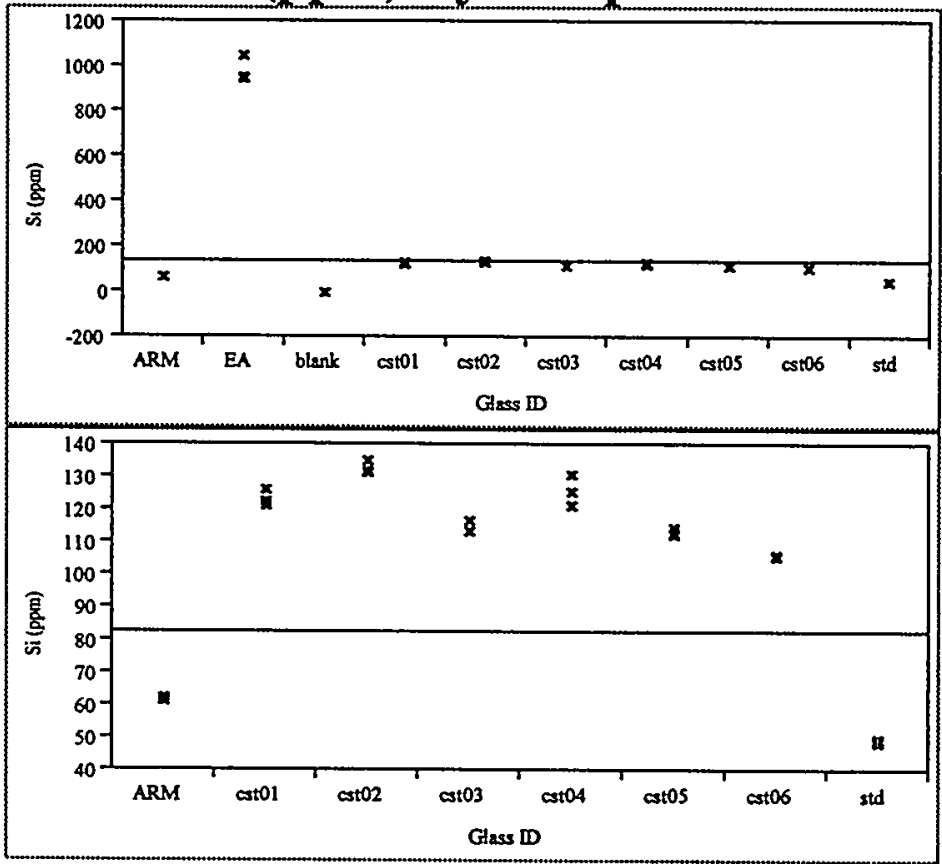


Exhibit A.5: Plots of the Leachate Concentrations by Sample ID by Element (with and without the EA and blank samples) (continued)

Na (ppm) By Sample ID

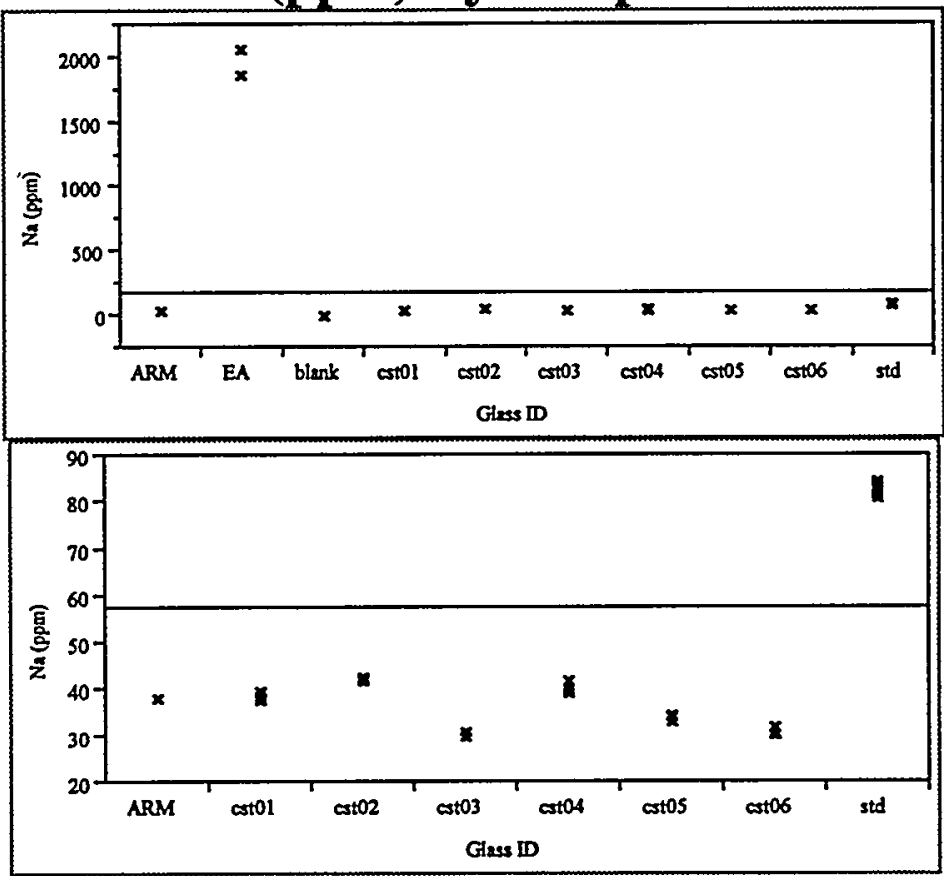

\section{Li (ppm) By Sample ID}
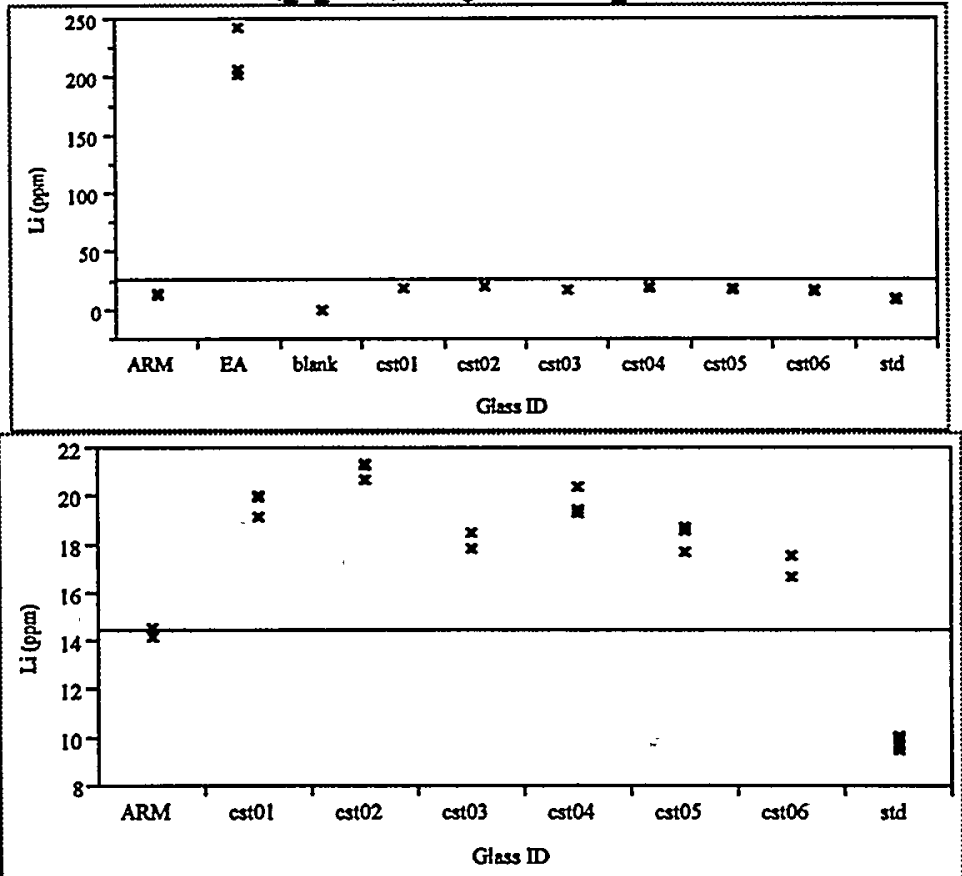
Exhibit A.6: Scatter Plots of the Normalized PCT's

Variable $\log$ NL[B $g / L]$

$\log \mathrm{NL}[\mathrm{Si} / \mathrm{L}]$

$\log \mathrm{NL}[\mathrm{Na} g / \mathrm{L}]$

$\log N L[\mathrm{Li} g / \mathrm{L}]$

\section{Correlations Using Target Compositions}

$\begin{array}{rrrr}\log N L[B \quad g / L] & \log N L[S i g / L] & \log N L[N a g / L] & \log N L[L i g / L] \\ 1.0000 & 0.8782 & 0.9675 & 0.8653 \\ 0.8782 & 1.0000 & 0.8556 & 0.9063 \\ 0.9675 & 0.8556 & 1.0000 & 0.9385 \\ 0.8653 & 0.9063 & 0.9385 & 1.0000\end{array}$

$\begin{array}{lrrrr}\text { Variable } & \log N L[B \text { g/L] } & \log N L[S i g / L] & \log N L[N a g / L] & \log N L[L i g / L] \\ \log N L[B g / L] & 1.0000 & 0.8503 & 0.9800 & 0.9690 \\ \log N L[S i g / L] & 0.8503 & 1.0000 & 0.8500 & 0.8787 \\ \log N L[N a g / L] & 0.9800 & 0.8500 & 1.0000 & 0.9955 \\ \log N L[L i \text { g/L] } & 0.9690 & 0.8787 & 0.9955 & 1.0000\end{array}$

\begin{tabular}{lrrrr}
\multicolumn{5}{c}{ Correlations Using Bias-Corrected Measured Compositions } \\
Variable & $\log N L[\mathrm{~B} g / \mathrm{L}]$ & $\log \mathrm{NL}[\mathrm{Si} g / \mathrm{L}]$ & $\log \mathrm{NL}[\mathrm{Na} g / \mathrm{L}]$ & $\log \mathrm{NL}[\mathrm{Li}$ g/L] \\
$\log \mathrm{NL}[\mathrm{B} \mathrm{g} / \mathrm{L}]$ & 1.0000 & 0.8395 & 0.9802 & 0.9692 \\
$\log \mathrm{NL}[\mathrm{Si} \mathrm{g} / \mathrm{L}]$ & 0.8395 & 1.0000 & 0.8307 & 0.8658 \\
$\log \mathrm{NL}[\mathrm{Na} / \mathrm{L}]$ & 0.9802 & 0.8307 & 1.0000 & 0.9955 \\
$\log \mathrm{NL}[\mathrm{Li} \mathrm{g} / \mathrm{L}]$ & 0.9692 & 0.8658 & 0.9955 & 1.0000
\end{tabular}
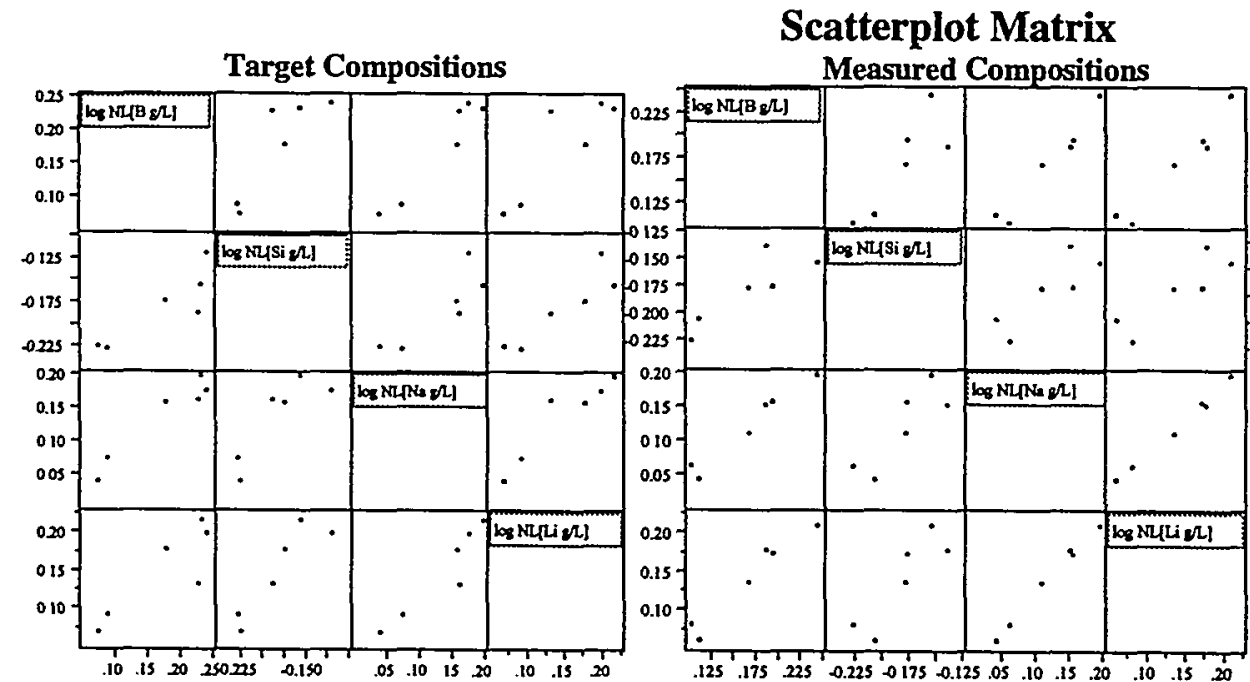

Bias-Corrected Measured Compositions

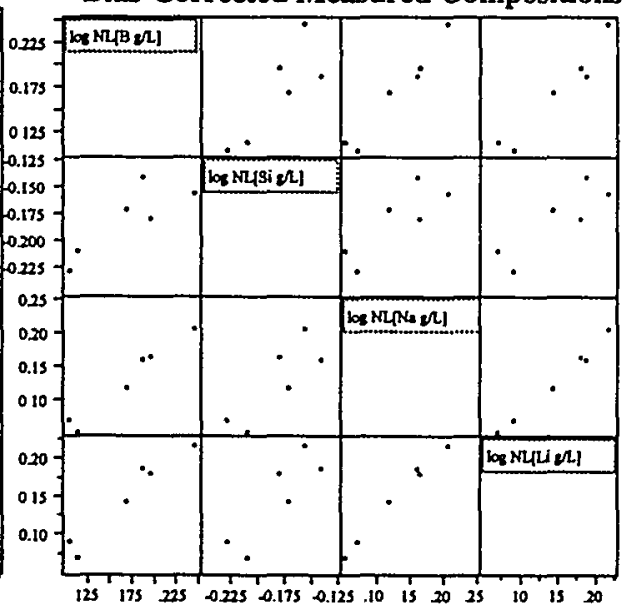




\section{Exhibit A.7: Durability Predictions versus Measured}

(Reference compositions were used to normalize the EA and ARM PCTs; their compositions were not remeasured as part of this study).

$\log N L(B)(g / L)$ By del $G p(m)$ (based on measured and bias-corrected compositions)

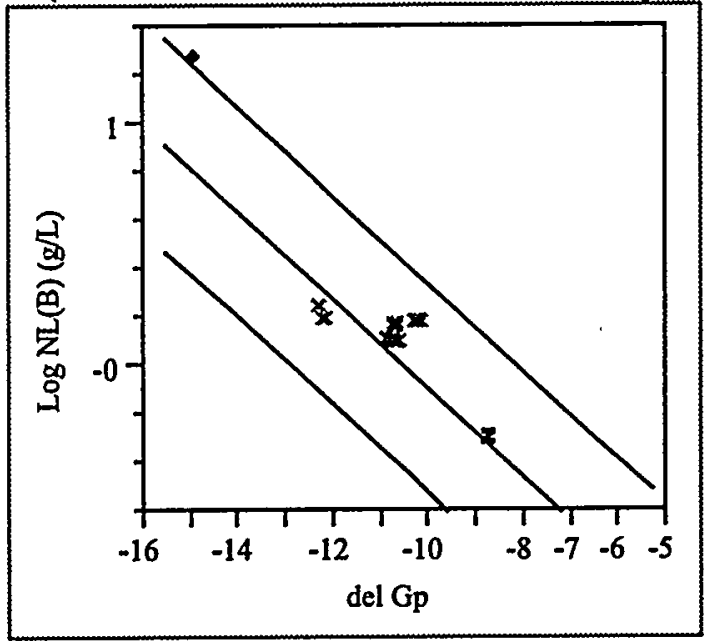

$\log$ NL(Si) (g/L) By del Gp(m) (based on measured and bias-corrected compositions)

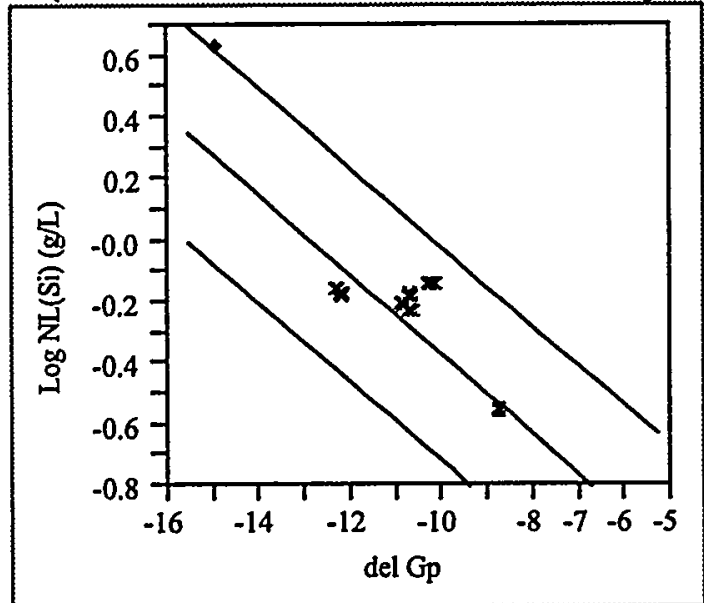

$\log N L(B)(g / L)$ By del $G p(m)$

(based on target composition)

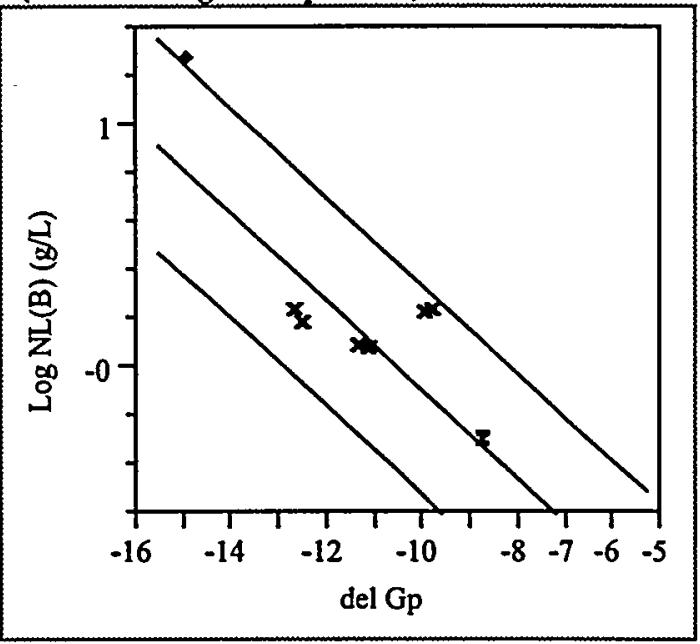

$\log \mathrm{NL}(\mathrm{Si})(\mathrm{g} / \mathrm{L}) \mathrm{By}$ del $\mathrm{Gp}(\mathrm{m})$ (based on target composition)

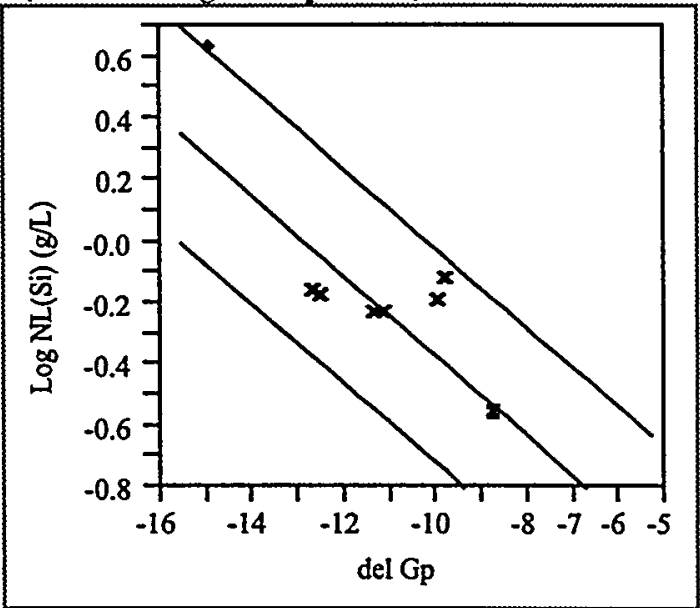




\section{Exhibit A.7: Durability Predictions versus Measured (Continued)}

(Reference compositions were used to normalize the EA and ARM PCTs; their compositions were not remeasured as part of this study).

$\log$ NL (Na) (g/L) By del Gp(m) (based on measured and bias-corrected compositions)

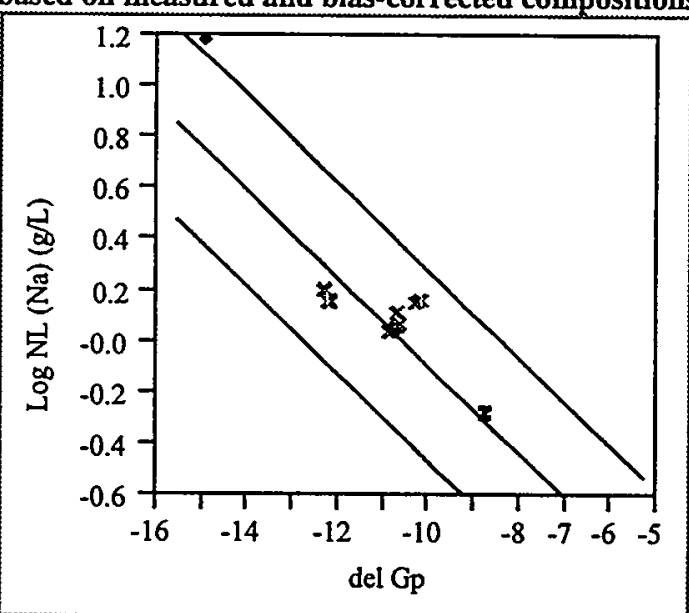

$\log [N L(L i) g / L]$ By del $G p(m)$ (based on measured and bias-corrected compositions)

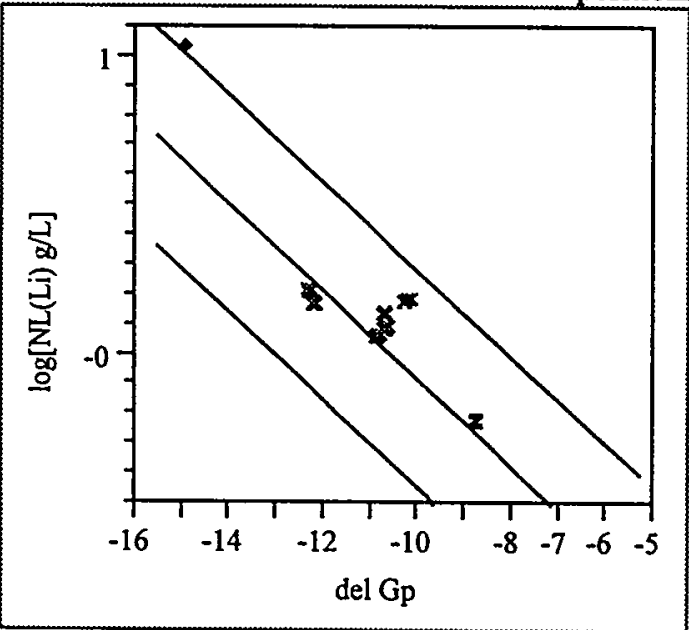

$\log N L(N a)(g / L)$ By del Gp(m)

(based on target composition)

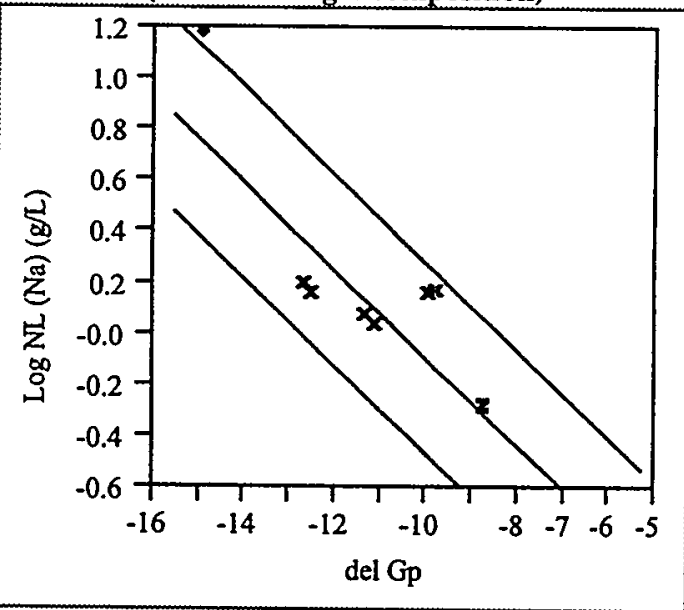

$\log [\mathrm{NL}(\mathrm{Li}) \mathrm{g} / \mathrm{L}]$ By del $\mathbf{G p}(\mathrm{m})$ (based on target composition)

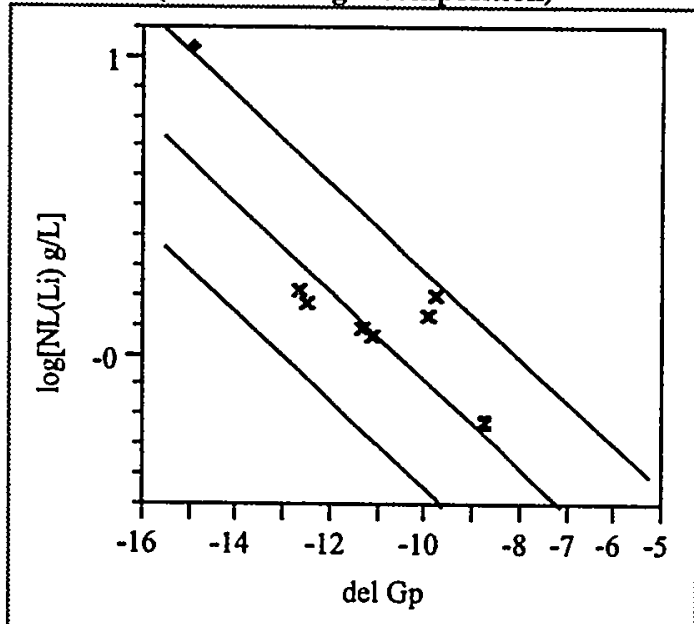


WSRC-TR-99-00292

Revision 0

Exhibit A.8: Viscosity Measurements, Fulcher Fits, and Predictions at $1150{ }^{\circ} \mathrm{C}$

pha01

$\begin{array}{lrr}\text { Parameter } & \text { Estimate } & \text { ApproxStdErr } \\ \text { A } & -3.52792291 & 0.09027284 \\ \text { B } & 6929.6311284 & 159.360098 \\ \text { C } & 202.04229825 & 10.0876431\end{array}$

Graph

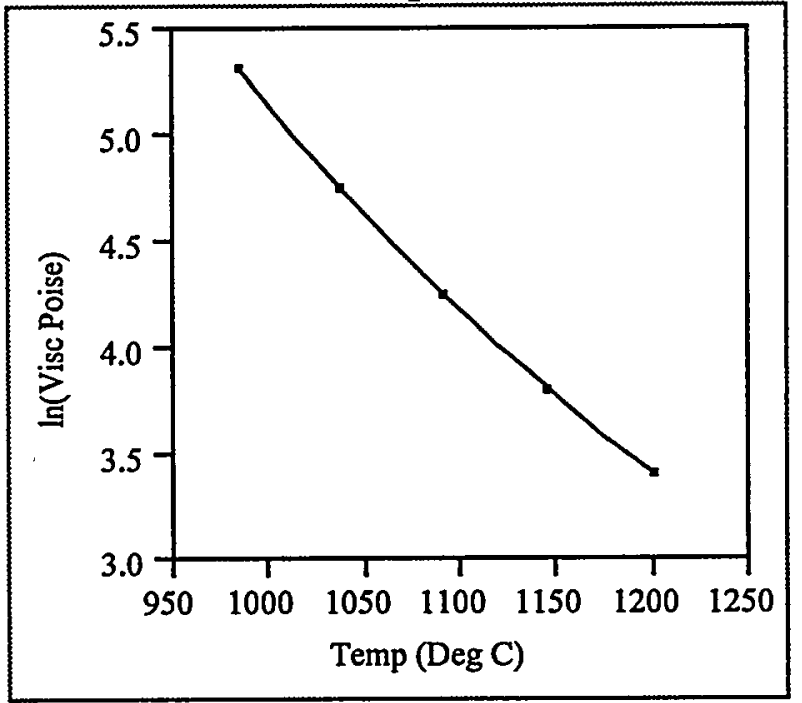

$\begin{array}{lrrrr}\text { Temp (Deg C) } & \text { Visc (Poise) } & \text { In Visc (Fulcher) } & \ln \text { (Visc Poise) } & \text { Visc Pred (Poise) } \\ 1201 & 30.24246 & 3.408938 & 3.409247 & 30.23 \\ 1146 & 45.24542 & 3.813117 & 3.812101 & 45.29 \\ 1092 & 70.79435 & 4.25855 & 4.259779 & 70.71 \\ 1038.5 & 116.2714 & 4.756574 & 4.755927 & 116.35 \\ 985.5 & 203.7991 & 5.31701 & 5.317135 & 203.77 \\ 1150 & ? & 3.782141 & ? & 43.91\end{array}$


Exhibit A.8: Viscosity Measurements, Fulcher Fits, and Predictions at $1150^{\circ} \mathrm{C}$ (continued)

\section{pha03}

$\begin{array}{lrr}\text { Parameter } & \text { Estimate } & \text { ApproxStdErr } \\ \text { A } & -3.365534533 & 0.36580795 \\ \text { B } & 6348.6671882 & 628.300941 \\ \text { C } & 225.15607459 & 42.2182192\end{array}$

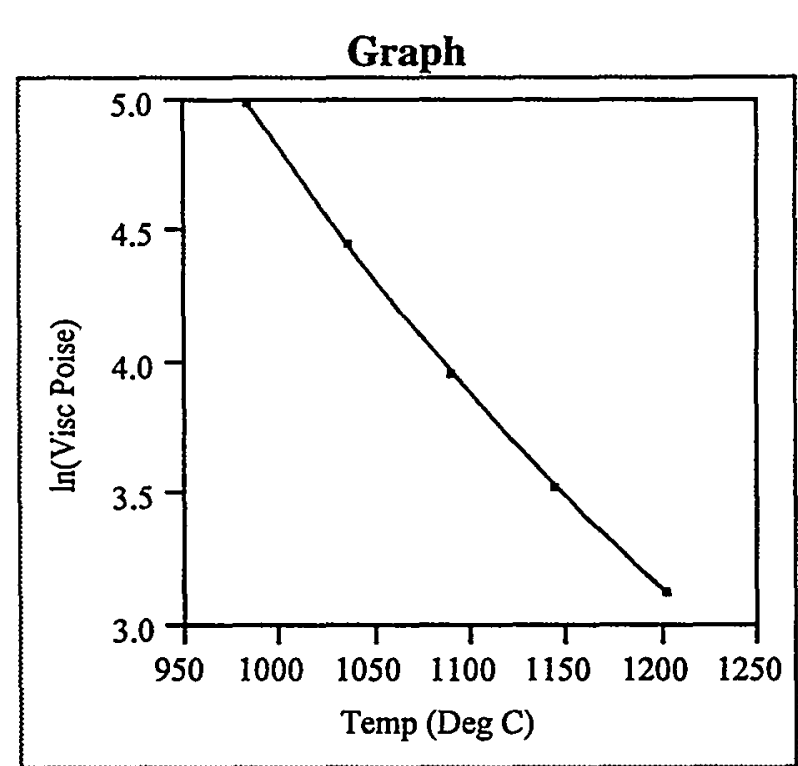

$\begin{array}{lrrrr}\text { Temp (Deg C) } & \text { Visc (Poise) } & \text { In Visc (Fulcher) } & \ln \text { (Visc Poise) } & \text { Visc Pred (Poise) } \\ 1202 & 23.00083 & 3.133628 & 3.13553 & 22.96 \\ 1145 & 34.26556 & 3.536362 & 3.534141 & 34.34 \\ 1091 & 52.63746 & 3.966811 & 3.963428 & 52.82 \\ 1037 & 86.52033 & 4.454524 & 4.460379 & 86.02 \\ 984 & 148.1978 & 5.000701 & 4.998548 & 148.52 \\ 1150 & ? & 3.499048 & ? & 33.08\end{array}$


WSRC-TR-99-00292

Revision 0

This page intentionally left blank.

WSRC Confidential and Proprietary Information. 


\section{Distribution}

J. L. Barnes, 704-3N

N. E. Bibler, 773-A

D. F. Bickford, 773-43A

K. G. Brown, 704-1T

J. T. Carter, 704-3N

J. J. Connelly, 773-41A

A. D. Cozzi, 77-43A

D. A. Crowley, 773-43A

T. B. Edwards, 773-42A

H. H. Elder, 704-S

S. D. Fink, 773-A

J. R. Harbour, 773-43A

E. W. Holtzscheiter, 773-A

R. A. Jacobs, 704-3N

C. M. Jantzen, 773-A

R. T. Jones, 704-3N

D. P. Lambert, 704-1T

L. F. Landon, 704-1T

S. L. Marra, 704-25S

D. B. Moore-Shedrow, 773-A

L. M. Papouchado, 773-A

D. K. Peeler, 773-43A

J. A. Pike, 704-3N

K. J. Rueter, 704-3N

R. F. Schumacher, 773-43A

M. E. Smith, 773-43A

T. K. Snyder, 704-1T

P. C. Suggs, 704-196N

W. L. Tamosaitis, 773-A

R. C. Tuckfield, 773-43A

R. J. Workman, 773-A

TIM (4 copies), 703-43A 